This document was prepared in conjunction with work accomplished under Contract No. DE-AC09-96SR18500 with the U. S. Department of Energy.

\title{
DISCLAIMER
}

This report was prepared as an account of work sponsored by an agency of the United States Government. Neither the United States Government nor any agency thereof, nor any of their employees, nor any of their contractors, subcontractors or their employees, makes any warranty, express or implied, or assumes any legal liability or responsibility for the accuracy, completeness, or any third party's use or the results of such use of any information, apparatus, product, or process disclosed, or represents that its use would not infringe privately owned rights. Reference herein to any specific commercial product, process, or service by trade name, trademark, manufacturer, or otherwise, does not necessarily constitute or imply its endorsement, recommendation, or favoring by the United States Government or any agency thereof or its contractors or subcontractors. The views and opinions of authors expressed herein do not necessarily state or reflect those of the United States Government or any agency thereof. 


\section{IMPACT OF SIMULANT PRODUCTION METHODS ON SRAT PRODUCT}

D. P. Lambert

R. E. Eibling

M. E. Stone

March 2006

Process Science \& Engineering Section Savannah River National Laboratory Aiken, SC 29808

Prepared for the U.S. Department of Energy Under Contract Number DEAC09-96SR18500

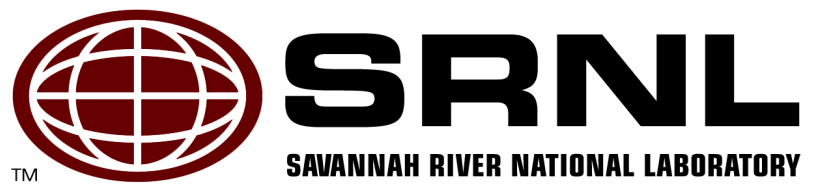




\section{DISCLAIMER}

This report was prepared by Washington Savannah River Company (WSRC) for the United States Department of Energy under Contract No. DE-AC09-96SR18500 and is an account of work performed under that contract. Neither the United States Department of Energy, nor WSRC, nor any of their employees makes any warranty, expressed or implied, or assumes any legal liability or responsibility for the accuracy, completeness, or usefulness, of any information, apparatus, or product or process disclosed herein or represents that its use will not infringe privately owned rights. Reference herein to any specific commercial product, process, or service by trademark, name, manufacturer, or otherwise does not necessarily constitute or imply endorsement, recommendation, or favoring of same by WSRC or by the United States Government or any agency thereof. The views and opinions of the authors expressed herein do not necessarily state or reflect those of the United States Government or any agency thereof.

\section{Printed in the United States of America \\ Prepared For U.S. Department of Energy}


Key Words: CPC, Sludge, SB4

SRAT, Rheology

Retention: Permanent

\section{IMPACT OF SIMULANT PRODUCTION METHODS ON SRAT PRODUCT}

D. P. Lambert

R. E. Eibling

M. E. Stone

March 2006

Process Science \& Engineering Section Savannah River National Laboratory Aiken, SC 29808 


\section{REVIEWS AND APPROVALS}

\section{AUTHORS:}

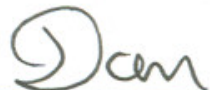

Par t

D. P. Lambert, Process Science \& Engineering Section

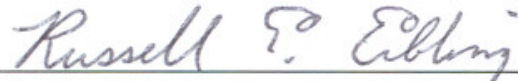

R. E. Eibling, Process Sciende \& Engineering Section

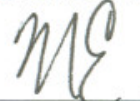

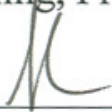

M. E. Stone, Process Science \& Engineering Section

$$
3-1-2006
$$

Date

Date

\section{TECHNICAL REVIEWER:}

Leaind Kropmen

D. C. Koopman, Process Science \& Engineering Section

$3 / 1 / 06$

$3 / 1 / 2006$

Date

\section{APPROVERS:}

YeEkdnasds

R. E. Edwards, Jr., Manager, Process Science \& Engineering Section

$3 / 0 / 06$

Aonne C Verma

Date

C. C. Herman, Manager, Process Engineering Technology

$\frac{3 / 7 / 06}{\text { Date }}$

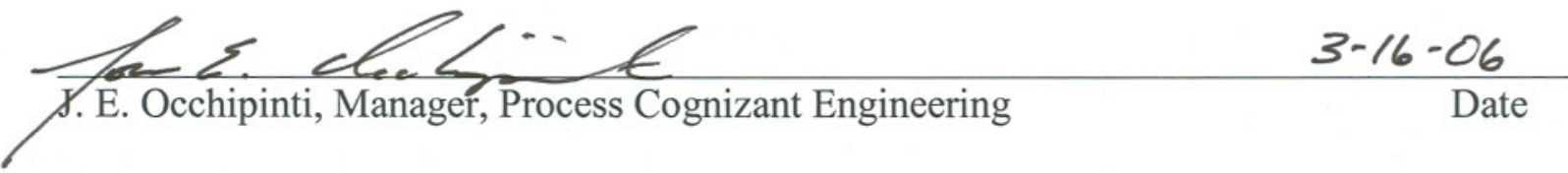




\section{EXECUTIVE SUMMARY}

Four 2-liter Sludge Receipt and Adjustment Tank (SRAT) cycles were performed: Tests ISPM-T1, ISPM-T6, ISPM-T7, and ISPM-T8. The purpose of these tests was to determine whether sludge simulant production methods have an impact on SRAT processing or SRAT product chemical and physical properties. All four runs used the same Sludge Batch 3 (SB3) chemical composition target but used different production methods. The important process parameters are as follows:

ISPM-T1 Baseline Feed, 155\% acid, No Hg, SRAT cycle

ISPM-T6 Coprecipitation of all metals except Al, 155\% acid, No Hg, SRAT cycle

ISPM-T7 Coprecipitation of all metals, $155 \%$ acid, No Hg, SRAT cycle

ISPM-T8 Coprecipitation of all metals with thermal treatment, 155\% acid, No Hg, SRAT cycle

This work is a continuation of a task to assess the impact of simulant production methods on the physical properties of Sludge Batch 3 simulant. $^{2}$ In the earlier task, eight batches of sludge were produced and characterized. In this study, four of the eight sludge batches were used to assess the impact of simulant production methods on the physical properties of DWPF Batch 3 SRAT product. The three batches which were closest to the physical properties of actual Batch 3 sludge ${ }^{3}$ were chosen along with the baseline sludge for comparison to earlier testing.

Results from processing the four sludge batches were as follows:

- The chemistry of the SRAT process does not mitigate the differences in rheology and particle size distribution between differently prepared sludges of the same nominal composition. Before testing began, it was hypothesized that the SRAT process would eliminate the physical property disparities on the differently prepared test sludges. If this had occurred, all of the products would have similar rheological properties. Instead, the conclusion from this study is that the SRAT does not eliminate physical property disparities between sludges prepared by different methods.

- No foaming or processing issues such as air entrainment were identified. The amount of antifoam used was within the current DWPF antifoam strategy.

- Visually, the sludge slurry and SRAT product appeared to be very thin, and slight problems were experienced with rapid solids settling when the material was not being mixed. No problems with mixing or heating were encountered.

- The chemical composition of the four starting sludge simulants and the four resulting SRAT products were very similar.

- The four $\mathrm{pH}$ profiles and resulting final $\mathrm{pH}$ of the SRAT products were very similar. As expected, the minimum SRAT $\mathrm{pH}$ occurred at the end of acid addition. The measured minimum $\mathrm{pH}$ ranged from 4.04-4.14. All runs had a SRAT product $\mathrm{pH}$ in the range of $\mathrm{pH} 4.62-4.94$.

- The formate destruction was very similar, the destruction efficiency varied from $11 \%$ to $22 \%$.

- The four SRAT products were concentrated by removing supernate to perform a rheology study. The more concentrated samples had the highest yield stress values. The average yield stress for the sheared SRAT product at $15 \mathrm{wt} \%$ insoluble solids ranged from 2.96-6.64 Pa or 29.6-66.4 dynes $/ \mathrm{cm}^{2}$. The highest yield stress was for the $15 \mathrm{wt} \%$ SRAT product from ISMP-T8.

- The plastic viscosity for the sheared SRAT product at $15 \mathrm{wt} \%$ insoluble solids ranged from 19.4$28.8 \mathrm{cp}$. The highest plastic viscosity was for the $15 \mathrm{wt} \%$ SRAT product from ISMP-T8.

- The yield stress of each of the four SRAT products was within the operating window for DWPF rheology. The sharp increase in yield stress of the $15 \mathrm{wt} \%$ insoluble solids ISMP-T8 SRAT product suggests that processing of these simulants above $15 \mathrm{wt} \%$ insoluble solids should be avoided. 
- The particle size distributions of the sludge from the three new fabrication methods and their SRAT products were very similar before and after the SRAT cycles. The particle size distribution of the baseline sludge changed considerably during processing with fewer small and large particles in the SRAT product. Each particle size analysis was completed without sonication of the sample.

- ISMP-T1 SRAT product had the smallest average particle size by volume while ISMP-T6 SRAT product had the largest particle size by volume. ISMP-T1 SRAT product also had the smallest average particle size by number, while ISMP-T8 SRAT product had the largest particle size by number.

- SRAT processing had minimal impact on the sludge particle size and particle distribution for ISMP-T8. The sludge used in ISMP-T8 had two peaks both before and after processing. The heat treatment and coprecipitation produced insoluble solids that were stable throughout the SRAT process. In contrast, the sludge for ISMP-T1 had a significant change in particle size as the result of the SRAT processing with the large particles becoming significantly smaller and the smallest particles becoming larger. The SRAT product had a single broad peak at approximately $10 \bullet \mathrm{m}$, while the starting sludge had two peaks. Also, the distribution of the two peaks was very different from the two peaks seen in the other tests 


\section{TABLE OF CONTENTS}

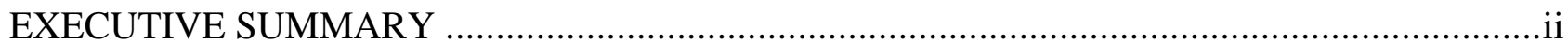

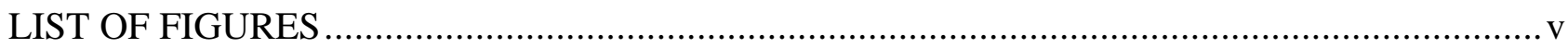

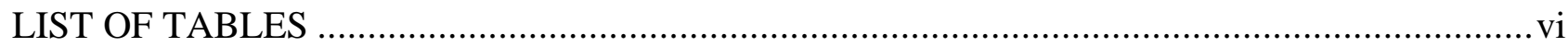

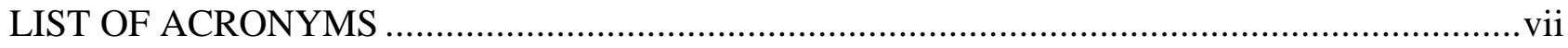

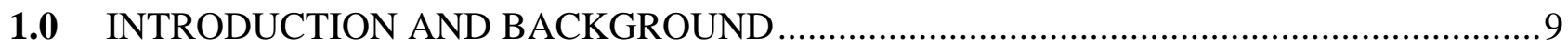

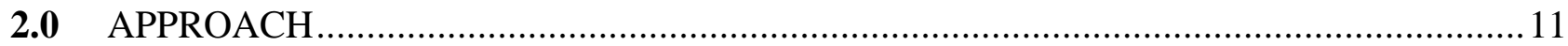

$2.1 \quad$ Sludge Simulant Preparation ............................................................................................................

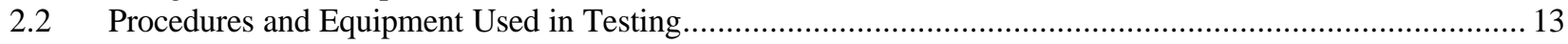

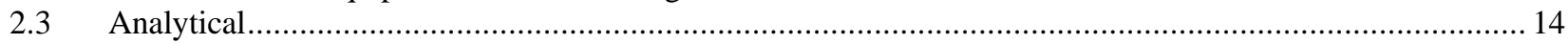

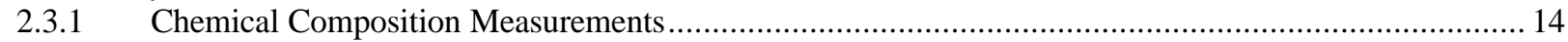

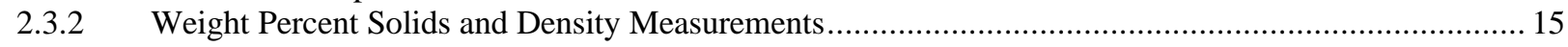

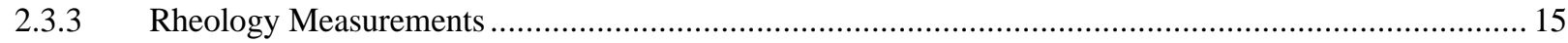

2.3.4 Particle Size Measurements......................................................................................................... 16

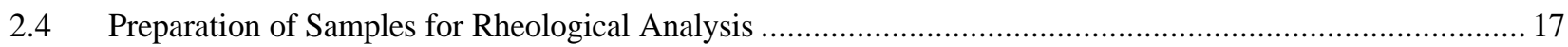

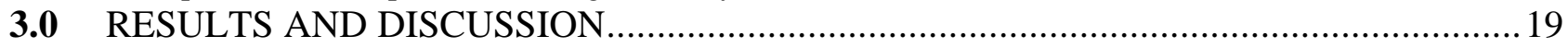

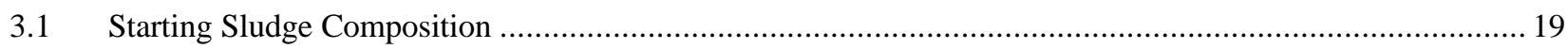

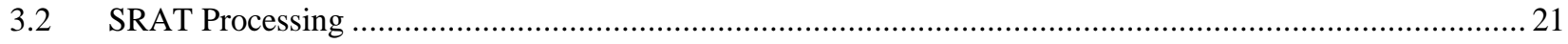

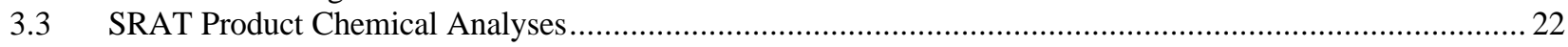

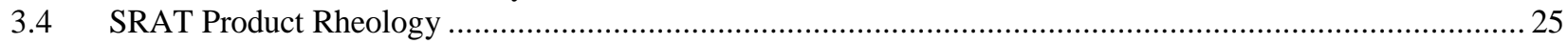

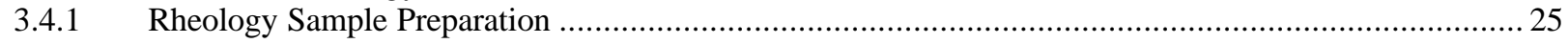

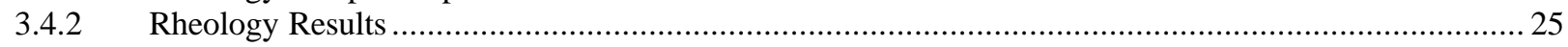

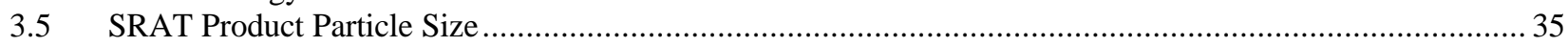

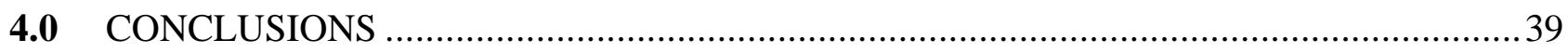

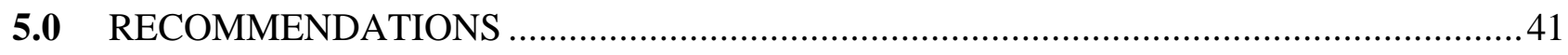

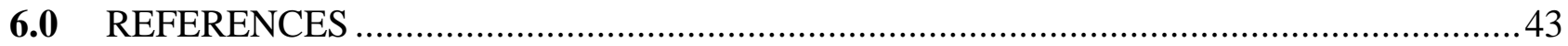

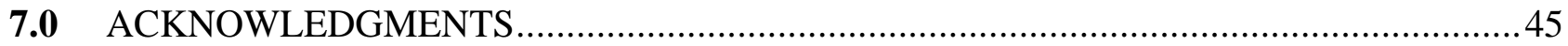

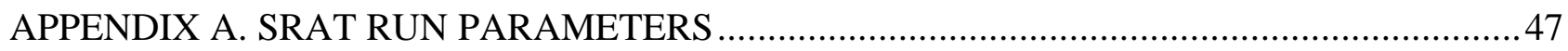

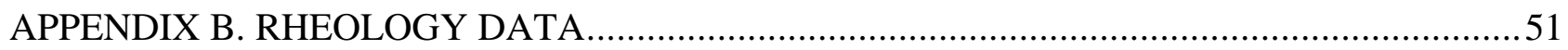




\section{LIST OF FIGURES}

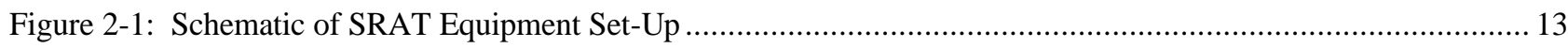

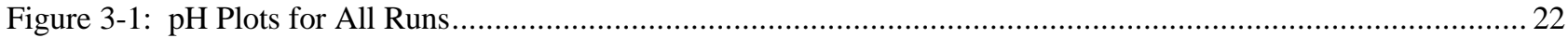

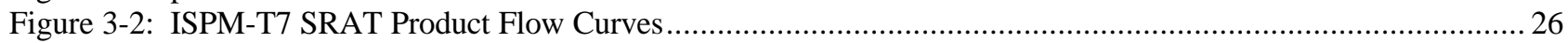

Figure 3-3: Yield Stress as a Function of Insoluble Solids for Sheared SRAT Product............................................ 30

Figure 3-4: Yield Stress as a Function of Insoluble Solids for Unsheared SRAT Slurries....................................... 30

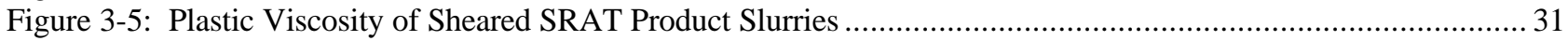

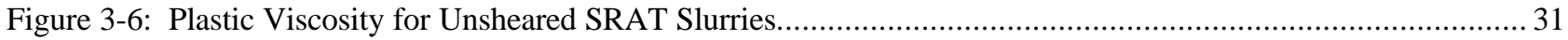

Figure 3-7: Rheology Model Equations for the Sheared Yield Stress Results......................................................... 33

Figure 3-8: Rheology Model Equations for the Unsheared Yield Stress Results..................................................... 34

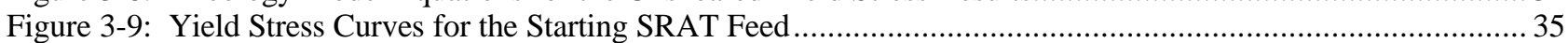

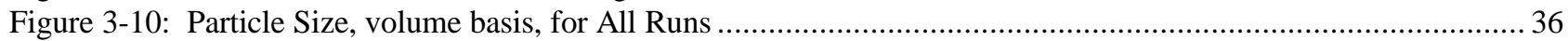

Figure 3-11: Particle Size, volume basis, for ISPM-T1 and ISPM-T8 ................................................................ 37

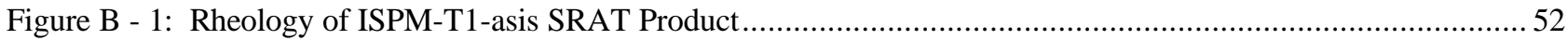

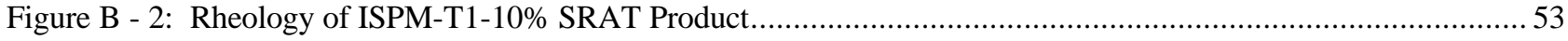

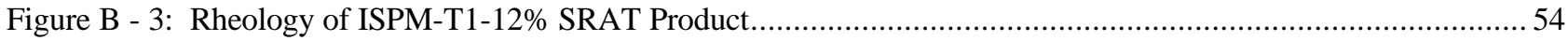

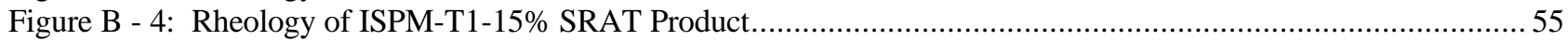

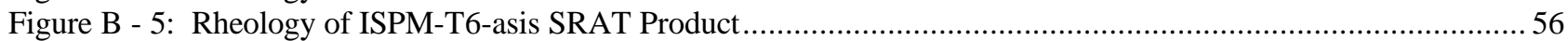

Figure B - 6: Rheology of ISPM-T6-10\% SRAT Product................................................................................ 57

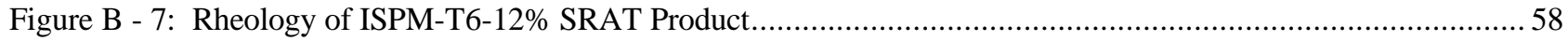

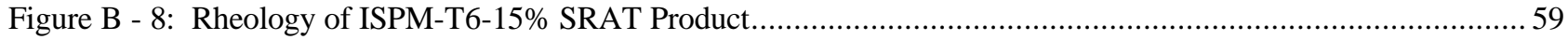

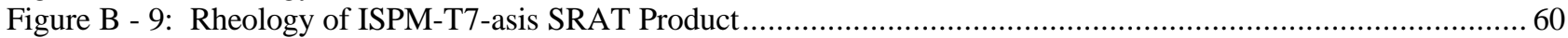

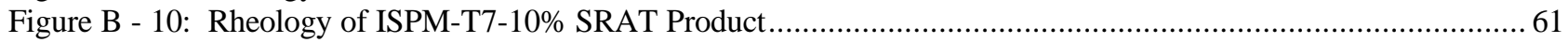

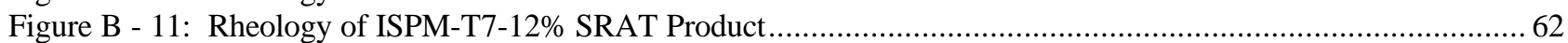

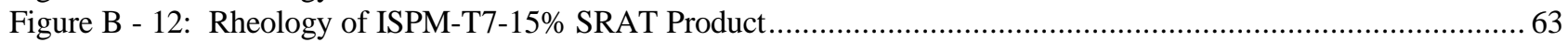

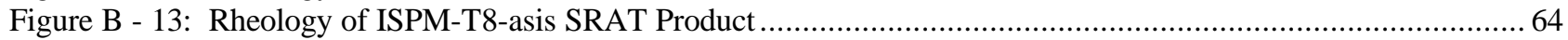

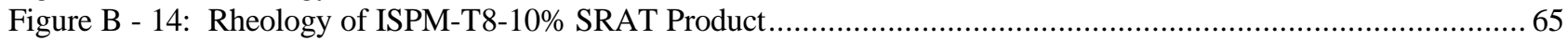

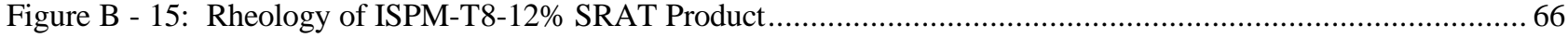

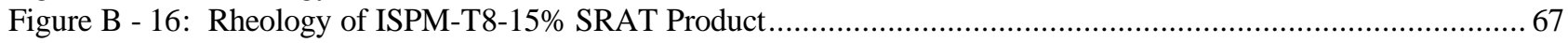




\section{LIST OF TABLES}

Table 2-1: Targeted SB3 Simulated Sludge Dried Solids Composition, wt \% ..................................................... 12

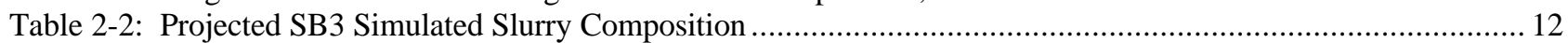

Table 2-3: Target Levels of Noble Metals Used in Testing............................................................................... 13

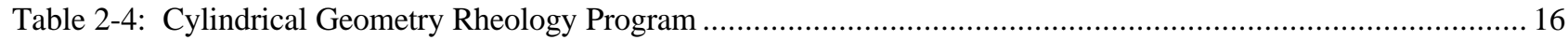

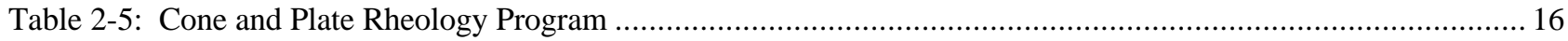

Table 2-6: Preparation of SRAT Products for Rheological Analyses ................................................................. 17

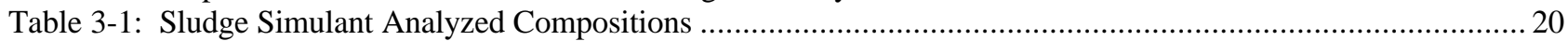

Table 3-2: Pre-Run Measured Inputs and Assumptions for Acid Calculation ......................................................... 21

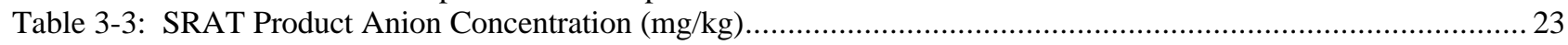

Table 3-4: Formate Destruction, Nitrate Conversion - SRAT Receipt Relative to SRAT Product .............................. 23

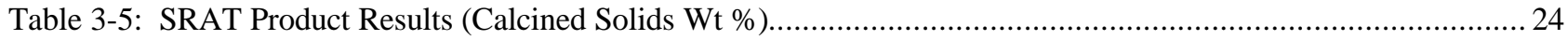

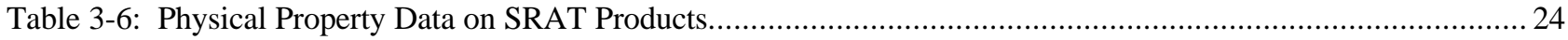

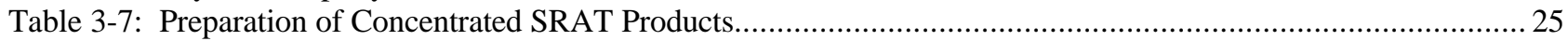

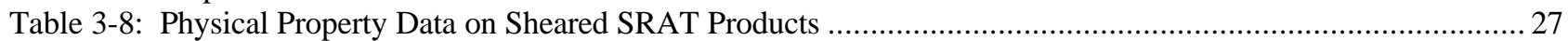

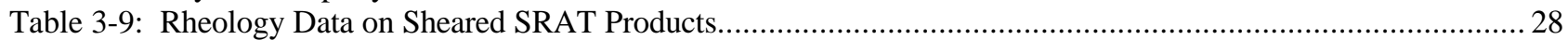

Table 3-10: Rheology Results for Unsheared SRAT Samples ............................................................................2 29

Table 3-11: Rheology Model Parameters for Sheared SRAT Products ................................................................ 33

Table 3-12: Rheology Model Parameters for Unsheared SRAT Products ............................................................... 34

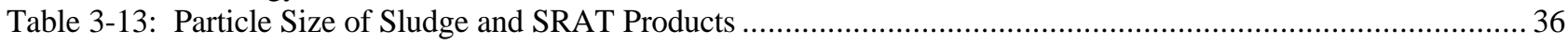

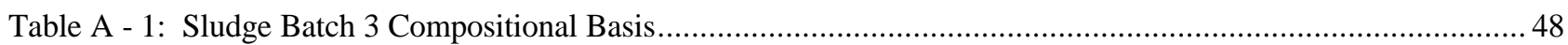

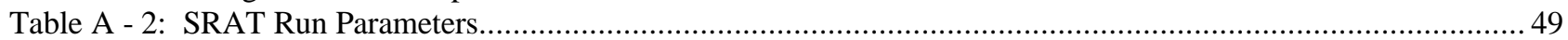




\section{LIST OF ACRONYMS}

$\begin{array}{ll}\text { ACTL } & \text { Aiken County Technologies Laboratory } \\ \text { ADS } & \text { Analytical Development Section } \\ \text { ASP } & \text { Analytical Study Plan } \\ \text { CBU } & \text { Closure Business Unit } \\ \text { CETL } & \text { Clemson Environmental Technologies Laboratory } \\ \text { cP } & \text { Centipoise } \\ \text { CPC } & \text { Chemical Process Cell } \\ \text { DWPF } & \text { Defense Waste Processing Facility } \\ \text { FAVC } & \text { Formic Acid Vent Condenser } \\ \text { GC } & \text { Gas Chromatograph } \\ \text { HLW } & \text { High Level Waste } \\ \text { IC } & \text { Ion Chromatography } \\ \text { ICP-AES } & \text { Inductively Coupled Plasma - Atomic Emission Spectroscopy } \\ \text { MCU } & \text { Modular Caustic Side Solvent Extraction Unit } \\ \text { MST } & \text { Monosodium Titanate } \\ \text { MWWT } & \text { Mercury Water Wash Tank } \\ \text { Pa } & \text { Pascals } \\ \text { PSE } & \text { Process Science \& Engineering Section } \\ \text { SB3 } & \text { Sludge Batch 3 } \\ \text { SB4 } & \text { Sludge Batch 4 } \\ \text { SME } & \text { Slurry Mix Evaporator } \\ \text { SMECT } & \text { Slurry Mix Evaporator Condensate Tank } \\ \text { SRAT } & \text { Sludge Receipt and Adjustment Tank } \\ \text { SRNL } & \text { Savannah River National Laboratory } \\ \text { TIC } & \text { Total Inorganic Carbon } \\ \text { TTR } & \text { Task Technical Request }\end{array}$


WSRC-TR-2005-00294

Revision 0

This page intentionally left blank. 


\subsection{INTRODUCTION AND BACKGROUND}

The research and development programs in support of the Defense Waste Processing Facility (DWPF) and other high level waste vitrification processes require the use of both nonradioactive waste simulants and actual waste samples. The nonradioactive waste simulants have been used for laboratory testing, pilot-scale testing and full-scale integrated facility testing. Recent efforts have focused on matching the physical properties of actual sludge. These waste simulants were designed to reproduce the chemical and, if possible, the physical properties of the actual high level waste. This technical report documents a study of simulant production methods for high level waste simulated sludge and their impact on the physical properties of the resultant SRAT product.

The sludge simulants used in support of DWPF have been based on average waste compositions and on expected or actual batch compositions. These sludge simulants were created to primarily match the chemical properties of the actual waste. These sludges were produced by generating manganese dioxide, $\mathrm{MnO}_{2}$, from permanganate ion $\left(\mathrm{MnO}_{4}{ }^{-}\right)$and manganous nitrate, precipitating ferric nitrate and nickel nitrate with sodium hydroxide, washing with inhibited water and then addition of other waste species. ${ }^{1}$ While these simulated sludges provided a good match for chemical reaction studies, they did not adequately match the physical properties (primarily rheology) measured on the actual waste.

A study was completed in FY04 to determine the impact of simulant production methods on the physical properties of Sludge Batch 3 simulant. ${ }^{2}$ This study produced eight batches of sludge simulant, all prepared to the same chemical target, by varying the sludge production methods. The sludge batch, which most closely duplicated the actual SB3 sludge physical properties, was Test 8 . Test 8 sludge was prepared by coprecipitating all of the major metals (including Al). After the sludge was washed to meet the target, the sludge simulant was heat treated at $98^{\circ} \mathrm{C}$ for eight hours.

Before testing began, it was hypothesized that the SRAT process would eliminate the rheology disparities on the differently prepared test sludges due to the chemistry of the SRAT process. If this hypothesis was true, all of the products would have similar rheological properties.

The objective of the project documented in this report was to determine the best method for producing a DWPF simulated sludge based on the physical properties of the SRAT product. In order to determine the best processing method, four SRAT cycles were completed using the four best sludge simulants.

The objectives of the testing were:

1. Produce four batches of SRAT product to be used primarily in a rheology study.

2. Develop an improved understanding of the impact of various methods of simulated sludge production on the physical properties of the SRAT product. 
WSRC-TR-2005-00294

Revision 0

This page intentionally left blank. 


\subsection{APPROACH}

This section describes the approach used to perform the initial Phase I testing. It is divided into four subsections. The first, Section 2.1, describes the sludge simulant composition and the preparation methods. Section 2.2 describes the procedures and equipment utilized in the testing. Section 2.3 describes the analytical methods and procedures used to characterize the sludge and SRAT products. Finally, Section 2.4 describes the preparation of SRAT product samples for rheology analysis.

\subsection{Sludge Simulant Preparation}

The targeted SB3 simulant composition is given in Table 2-1. The compositional basis is derived from the composition of two dip samples collected from Tank 40H in March 2003. ${ }^{3}$ The targeted slurry composition is given in Table 2-2. Table A - 1 shows the typical recipe for the baseline sludge. No uranium was added to the simulant, and no other materials were substituted for the uranium. The recipe was not adjusted for the lack of uranium, but instead the ratios of the various elements to iron were held constant. The preparation of the SB3 sludge simulants are described in a FY04 report. $^{2}$ The recipe was followed for fabrication, and the resulting sludge was analyzed before testing was initiated.

One significant difference in composition between the actual high level SB3 sludge waste and the SB3 simulants is the concentration of insoluble solids. The insoluble solids measured in SB3 was $14.8 \mathrm{wt} \%$. The insoluble solids in the four sludges produced by gravity settling varied from $6.85 \mathrm{wt} \%$ to $7.99 \mathrm{wt} \%$. This is the maximum concentration of insoluble solids sludge that could be produced using the gravity settling method with a limited settling time. As a result, there is more supernate and less insoluble solids by mass in the simulant than the actual waste.

Before each run, noble metals were added to the sludge in the SRAT vessel to ensure that the small quantities were present at the targeted concentrations. Table 2-3 shows the targeted levels of noble metals. The sludges were not re-analyzed after the noble metals were added since they have a minimal impact on the overall composition. 
Table 2-1: Targeted SB3 Simulated Sludge Dried Solids Composition, wt \%

\begin{tabular}{|c|c|}
\hline Sludge Feed ID & Target \\
\hline Al & 6.04 \\
\hline Ba & 0.05 \\
\hline $\mathbf{C a}$ & 1.66 \\
\hline $\mathrm{Cr}$ & 0.25 \\
\hline $\mathrm{Cu}$ & 0.03 \\
\hline $\mathbf{F e}$ & 19.44 \\
\hline $\mathbf{K}$ & 0.33 \\
\hline Mg & 1.67 \\
\hline Mn & 3.95 \\
\hline $\mathbf{N a}$ & 13.84 \\
\hline $\mathbf{N i}$ & 1.09 \\
\hline $\mathbf{P}$ & 0.43 \\
\hline $\mathbf{P b}$ & 0.06 \\
\hline $\mathbf{S}$ & 0.29 \\
\hline Si & 0.4 \\
\hline $\mathbf{T i}$ & 0.02 \\
\hline $\mathbf{Z n}$ & 0.03 \\
\hline $\mathbf{Z r}$ & 0.01 \\
\hline
\end{tabular}

Table 2-2: Projected SB3 Simulated Slurry Composition

\begin{tabular}{||l|c||}
\hline PARAMETER & BASELINE \\
\hline $\mathrm{SpGr}(\mathrm{kg} / \mathrm{L})$ & 1.19 \\
\hline $\mathrm{Na}(\mathrm{M})$ & $1.43 \mathrm{E}+00$ \\
\hline $\mathrm{NO}_{2}(\mathrm{M})$ & $4.0 \mathrm{E}-01$ \\
\hline $\mathrm{NO}_{3}(\mathrm{M})$ & $2.02 \mathrm{E}-01$ \\
\hline $\mathrm{OH}(\mathrm{M})$ & $4.30 \mathrm{E}-01$ \\
\hline $\mathrm{Cl}(\mathrm{M})$ & $6.71 \mathrm{E}-03$ \\
\hline $\mathrm{SO}_{4}(\mathrm{M})$ & $4.18 \mathrm{E}-02$ \\
\hline $\mathrm{F}(\mathrm{M})$ & $1.47 \mathrm{E}-02$ \\
\hline $\mathrm{CO}_{3}(\mathrm{M})$ & $2.44 \mathrm{E}-01$ \\
\hline $\mathrm{AlO}_{2}{ }^{-2}(\mathrm{M})$ & NA \\
\hline $\mathrm{C}_{2} \mathrm{O}_{4}{ }^{-2}(\mathrm{M})$ & $2.79 \mathrm{E}-02$ \\
\hline $\mathrm{PO}_{4}{ }^{-3}(\mathrm{M})$ & $9.91 \mathrm{E}-02$ \\
\hline $\mathrm{K}_{(\mathrm{M})}$ & $2.01 \mathrm{E}-02$ \\
\hline Insoluble Solids $(w t \%)$ & 14.8 \\
\hline Total Solids (wt \%) & 20 \\
\hline
\end{tabular}


WSRC-TR-2005-00294

Revision 0

Table 2-3: Target Levels of Noble Metals Used in Testing

\begin{tabular}{||c|c||}
\hline Noble Metal & Wt\% in Total Solids \\
\hline $\mathrm{Ag}$ & $0.0300^{*}$ \\
\hline $\mathrm{Pd}$ & 0.0014 \\
\hline $\mathrm{Rh}$ & 0.0076 \\
\hline $\mathrm{Ru}$ & 0.0360 \\
\hline \multicolumn{2}{|c|}{$* \mathrm{Ag}$ added with original sludge preparation }
\end{tabular}

\subsection{Procedures and Equipment Used in Testing}

The testing was performed at the Aiken County Technology Laboratory (ACTL) using 2-liter kettles with glassware fabricated to functionally replicate the DWPF processing vessels. The 2-L glass kettle is used to replicate the SRAT, and it is connected to the SRAT Condenser, the Mercury Water Wash Tank (MWWT), the Slurry Mix Evaporator Condensate Tank (SMECT), and the Formic Acid Vent Condenser (FAVC). For the purposes of this paper, the condensers and wash tank are referred to as the offgas components. No offgas analysis was completed as part of this testing. A sketch of the experimental setup is given as Figure 2-1.

Figure 2-1: Schematic of SRAT Equipment Set-Up

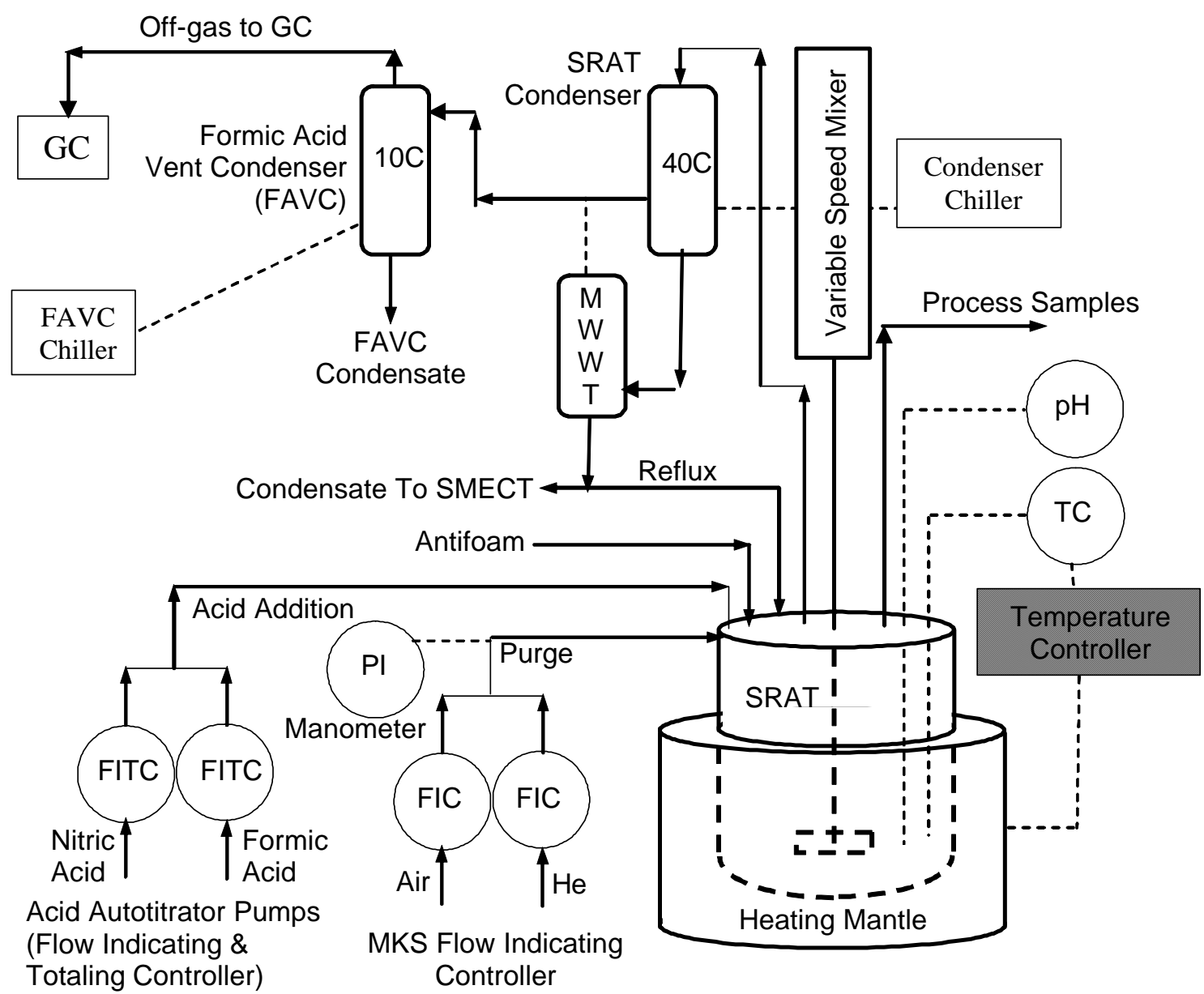


SRAT processing parameters for the four SRAT cycles are summarized in Appendix A, Table A - 2. Each SRAT test followed the run plans written for ISPM-T $1^{4}$, ISPM-T6 ${ }^{5}$, ISPM-T $7^{6}$, ISPM-T $8^{7}$, and the memo numbers are given in Table A - 2. The runs were performed in accordance with Procedure ITS-0094 ("Laboratory Scale Chemical Process Cell Simulations") of Manual L29. One significant deviation from normal processing was that dewatering was completed after the twelve-hour reflux period was complete. Slurry $\mathrm{pH}$ and temperature were measured during these experiments using in-line instrumentation. During the runs, the kettle was monitored to observe reactions that were occurring during each run, and to observe foaming, air entrainment, rheology changes, loss of heat transfer capabilities, and offgas carryover. Observations were recorded in laboratory notebook WSRC-NB-2005-00032 and are discussed in Section 3.0.

Concentrated nitric acid (50-wt\%, $10.53 \mathrm{M})$ and formic acid (90-wt\%, $23.60 \mathrm{M})$ were used to acidify the sludge and perform neutralization and reduction reactions during processing. The amounts of acid to add for each run were determined using the existing DWPF acid addition equation. The split of the acid was determined using the redox equation currently being used in DWPF processing ${ }^{8}$. The redox $\operatorname{target}\left(\mathrm{Fe}^{2+} / \bullet \mathrm{Fe}\right)$ was 0.2 . To account for the reactions and anion destructions that occur during processing, assumptions about nitrite destruction, nitrite to nitrate conversion, and formate destruction were made for each run. The values used for each run are provided in Section 3.0.

To prevent foaming during processing, 200 ppm IIT 747 antifoam was added during heat-up at $40^{\circ} \mathrm{C}$ and 500 ppm was added at the completion of acid addition. SRAT processing included 12 hours of reflux plus the dewater time at boiling to remove the appropriate amount of waster to produce a SRAT product at $22.7 \mathrm{wt} \%$ total solids. The dewater time for all of the runs is given in Table A - 2 of Appendix A.

\subsection{Analytical}

Analyses for this task used the guidance of Analytical Study Plan ${ }^{9}$. Sample request forms were used for samples to be analyzed, and analyses followed the guidelines and means of sample control stated in the Analytical Study Plan for the task. A unique ITS, Immobilization Technology Section - Mobile Lab (Mobile Lab), and/or Analytical Development Section (ADS) lab identification number was assigned to each sample for tracking purposes. Analyses were performed using approved analytical and QA procedures.

\subsubsection{Chemical Composition Measurements}

Samples were taken of each batch of sludge simulant before the runs were initiated and of each batch of SRAT product at the end of the cycles for analyses. The samples were analyzed by the Mobile Lab, the ITS, and the ADS. The Mobile Lab performed analyses on the sludge slurries to determine the chemical composition, total and dissolved solids, density, and $\mathrm{pH}$. Samples for anion analyses were prepared using weighted dilutions and were analyzed using Ion Chromatography (IC). The chemical composition was determined in duplicate by calcining the samples at $1100{ }^{\circ} \mathrm{C}$ and then dissolving the product using $\mathrm{Na}_{2} \mathrm{O}_{2} / \mathrm{NaOH}$ fusion and lithium metaborate fusion. The preparations were then analyzed using Inductively Coupled Plasma - Atomic Emission Spectroscopy (ICP-AES) to measure the cations present. The total and dissolved solids were measured on two aliquots and the insoluble and soluble solids fractions were calculated from the results. Density and $\mathrm{pH}$ measurements of the samples were also performed on the initial and product samples. ITS performed the titration on the starting sludge samples to provide the necessary input for the acid calculation. A manual titration was performed at ACTL using a 1M $\mathrm{HNO}_{3}$ solution and 10:1 dilution of the sample. The calibration curve was performed to a $\mathrm{pH}$ of 4 and was performed in duplicate at a minimum. Finally, the ADS measured the total inorganic carbon (TIC) of the sludge simulant using the ITS Acid Demand TIC method. The total inorganic carbon information was needed as an input in the acid calculation. 


\subsubsection{Weight Percent Solids and Density Measurements}

The weight percent solids were determined using a Mettler Toledo HR73P Halogen Moisture Analyzer. The HR73P is programmed to heat the sample to $105^{\circ} \mathrm{C}$ and monitor the mass of the sample until the change in mass is less than or equal to $1 \mathrm{mg}$ over a period of 130 seconds. The advantage of this method is that a weight percent solids analysis can be performed in less than 20 minutes, while a complete analysis of total solids in the sludge and dissolved solids in the supernate can take less than an hour. The homogenous sample (slurry or liquid) is placed on a glass fiber pad and the pad placed in the HR73P. The HR73P weighs the sample. The initial mass of the sample is the total mass $\left(\mathrm{m}_{\mathrm{t}}\right)$. The sample is then heated by the infrared radiation from a Halogen lamp to $105^{\circ} \mathrm{C}$ (controlled by a thermocouple) to drive off all the water (assuming mass loss is only from water) and the resulting remaining mass is the total solids $\left(\mathrm{m}_{\mathrm{ts}}\right)$ in the sample. The weight percent (wt \%) total solids (TS) of the sludge was determined using equation [1].

$$
w t \%_{t s}=\frac{m_{t s}}{m_{t t}} \times 100 \%
$$

A sample of the slurry was centrifuged (at 4332 gravities) to obtain the supernate. The resulting supernate was then processed through a $0.45 \mu \mathrm{m}$ filter. A sample of the filtered supernate was then placed on a glass fiber pad, placed in the HR73P, and weighed. The mass of sample used was considered as the total mass of the supernate $\left(\mathrm{m}_{\mathrm{st}}\right)$. The sample was then heated by the Halogen lamp to $105^{\circ} \mathrm{C}$ to drive off all the water and the resulting remaining mass was the total dissolved solids $\left(\mathrm{m}_{\mathrm{ds}}\right)$ in the supernate. The weight percent of total dissolved solids (DS) in the supernate was determined using equation [2]. This analysis assumes that all the solids in the resulting supernate were dissolved.

$$
w t \%_{d s}=\frac{m_{d s}}{m_{s t}} \times 100 \%
$$

The weight percent of insoluble solids (IS) and soluble solids (SS) of the slurry are then calculated by the following conservation of mass relationships, equations [3] and [4] respectively.

$$
\begin{gathered}
w t \%_{i s}=\frac{w t \%_{t s}-w t \%_{d s}}{100 \%-w t \%_{d s}} \times 100 \% \\
w t \%_{s s}=w t \%_{t s}-w t \%_{i s}
\end{gathered}
$$

Density was determined using an Anton Paar DMA 4500 density meter. The density meter determines the density of a sample by measuring the resonant frequency of a sample-filled $U$ tube at a specified temperature.

\subsubsection{Rheology Measurements}

Slurry rheology measurements were performed using a Haake RS600 rheometer at $25^{\circ} \mathrm{C}$. The rheometer uses a Searle type measuring system, where both speed and torque are measured at the rotating shaft. The rheometer was operated in the controlled rate mode for all of the data reported in this report. A few measurements were also made in the controlled stress mode when additional clarification of a rheology result was needed but are not reported. The measuring geometries used were the cylindrical sensor and cup (Z41 Ti) for the less viscous slurries (when sufficient sample was available) and the cone and plate (60 $\mathrm{mm}$ $\mathrm{Ti} / 2$ degree) for the slurries that were too thick for loading into the cylindrical geometry or for small samples (which were the majority of samples), which had insufficient material for the cup geometry. The thick slurries were produced by concentrating the SRAT product through supernate removal. 
Flow curves were obtained by linearly varying the shear rate from 0 to 600 seconds $^{-1}$ over a given time period. The program details for the flow curves are listed in Table 2-4 and Table 2-5 for the cylindrical and cone geometries respectively. The measured shear stresses for the linear portion of the up and down flow curves were fitted to the Bingham Plastic rheology model (equation 5) over the shear rate range of 50 to 600 seconds ${ }^{-1}$.

$$
\begin{aligned}
& \qquad=\tau_{0}+\eta_{0} \mathcal{} \propto \\
& \tau=\text { shear stress, } \mathrm{Pa} \\
& \tau_{0}=\text { Bingham Yield Stress, } \mathrm{Pa} \\
& \mathcal{\alpha}=\text { Shear rate, } 1 / \text { seconds } \\
& \eta_{0}=\text { Bingham consistency, mPa.sec (or cP) }
\end{aligned}
$$

The upper limit for the fitted shear rate region was adjusted to a lower value of shear rate when necessary to avoid nonlaminar flow conditions. The lower limit for the fitted shear rate region was adjusted to the start of the linear portion of the curve after any initial hump as long as the shear stress increased with increasing shear rate (positive slope). For any flow curve that did not show a positive slope to the flow curve, the yield stress was taken as the maximum observed in the flow curve.

Table 2-4: Cylindrical Geometry Rheology Program

\begin{tabular}{|c|c|c|}
\hline $\begin{array}{c}\text { Program } \\
\text { Section }\end{array}$ & $\begin{array}{c}\text { Shear rate, } \\
\text { seconds }^{-1}\end{array}$ & $\begin{array}{c}\text { Time, } \\
\text { minutes }\end{array}$ \\
\hline Up Curve & 0 to 600 & 5 \\
\hline Hold Period & 600 & 1 \\
\hline Down Curve & 600 to 0 & 5 \\
\hline
\end{tabular}

Table 2-5: Cone and Plate Rheology Program

\begin{tabular}{|c|c|c|}
\hline Program Section & Shear rate, seconds $^{-1}$ & Time, minutes \\
\hline Up Curve & 0 to 600 & 5 \\
\hline Hold Period & 600 & 1 \\
\hline Down Curve & 600 to 0 & 5 \\
\hline
\end{tabular}

\subsubsection{Particle Size Measurements}

Particle size analysis was obtained by submitting samples to the Analytical Development Section for analysis. Samples were analyzed with a Microtrac S3000 Tri-laser Particle Size Analyzer. This instrument uses angular light scattering techniques to measure the particle size distribution. Preparation of the samples for analysis by the Microtrac consists of dilution of the slurry with water. The particle size distribution can be expressed in terms of a volume distribution, number distribution or area distribution. In this report, the graphical display of particle size data will use the volume distribution. The calculated mean of the volume, number and area distributions will also be reported. It should be noted that the mean for a volume distribution is weighted toward the larger particles while the mean for the number distribution is weighted toward the smaller particles. ${ }^{2}$ The calculated specific surface area in meters ${ }^{2} / \mathrm{cm}^{3}$ is based on an assumption of smooth, solid spherical particles and does not reflect porosity or topology of the particles. 


\subsection{Preparation of Samples for Rheological Analysis}

The SRAT product samples were concentrated by the removal of supernate to prepare four samples from each run for rheological analysis. The four concentrations were as received, $10 \mathrm{wt} \%, 12 \mathrm{wt} \%$ and $15 \mathrm{wt} \%$ insoluble solids. The concentration targets were calculated knowing the total solids of the slurry and filtrate from each run. The calculated quantity of supernate to be removed for each test is summarized in Table 2-6.

Table 2-6: Preparation of SRAT Products for Rheological Analyses

Sample \# 1, as is, need $5 \mathrm{~mL}(6 \mathrm{~g})$ per sample cone and plate, analyze in duplicate

\begin{tabular}{|l|c|l|l|l|c|c|c|c|c|}
\hline & $\begin{array}{c}\text { Initital } \\
\text { Mass, } \\
\mathrm{g}\end{array}$ & $\begin{array}{l}\text { Final } \\
\text { Mass, } \\
\mathrm{g}\end{array}$ & $\begin{array}{l}\text { Removed } \\
\text { Supernate }\end{array}$ & $\begin{array}{l}\text { Insoluble } \\
\text { Solids } \\
\text { Mass, g }\end{array}$ & $\begin{array}{l}\text { Soluble } \\
\text { Solids } \\
\text { Mass, g }\end{array}$ & $\begin{array}{l}\text { Total } \\
\text { Solids, g }\end{array}$ & $\begin{array}{l}\text { Water } \\
\text { Mass, g }\end{array}$ & $\begin{array}{l}\text { Insoluble } \\
\text { Solids, } \\
\text { wt \% }\end{array}$ & $\begin{array}{c}\text { Total } \\
\text { Solids, } \\
\text { wt \% }\end{array}$ \\
\hline SBT1 & 100.0 & 100.0 & 0.0 & 6.59 & 14.55 & 21.14 & 78.86 & $6.59 \%$ & $21.14 \%$ \\
\hline SBT6 & 100.0 & 100.0 & 0.0 & 7.47 & 14.35 & 21.82 & 78.18 & $7.47 \%$ & $21.82 \%$ \\
\hline SBT7 & 100.0 & 100.0 & 0.0 & 5.95 & 14.38 & 20.33 & 79.67 & $5.95 \%$ & $20.33 \%$ \\
\hline SBT8 & 100.0 & 100.0 & 0.0 & 5.78 & 14.98 & 20.76 & 79.24 & $5.78 \%$ & $20.76 \%$ \\
\hline
\end{tabular}

Sample \#2, remove supernate until $10 \%$ insoluble solids

\begin{tabular}{|c|c|c|c|c|c|c|c|c|c|}
\hline & $\begin{array}{c}\text { Initital } \\
\text { Mass, } \\
\text { g }\end{array}$ & $\begin{array}{l}\text { Final } \\
\text { Mass, } \\
\mathrm{g}\end{array}$ & $\begin{array}{l}\text { Removed } \\
\text { Supernate }\end{array}$ & $\begin{array}{l}\text { Insoluble } \\
\text { Solids } \\
\text { Mass, g }\end{array}$ & $\begin{array}{l}\text { Soluble } \\
\text { Solids } \\
\text { Mass, g }\end{array}$ & $\begin{array}{l}\text { Total } \\
\text { Solids, g }\end{array}$ & $\begin{array}{l}\text { Water } \\
\text { Mass, g }\end{array}$ & $\begin{array}{c}\text { Insoluble } \\
\text { Solids, } \\
\text { wt } \%\end{array}$ & $\begin{array}{c}\text { Total } \\
\text { Solids, } \\
\text { wt \% }\end{array}$ \\
\hline SBT1 & 100.0 & 65.9 & 34.1 & 6.59 & 9.24 & 15.83 & 50.07 & $10.0 \%$ & $24.0 \%$ \\
\hline SBT6 & 100.0 & 74.7 & 25.3 & 7.47 & 10.43 & 17.90 & 56.80 & $10.0 \%$ & $24.0 \%$ \\
\hline SBT7 & 100.0 & 59.5 & 40.5 & 5.95 & 8.19 & 14.14 & 45.36 & $10.0 \%$ & $23.8 \%$ \\
\hline SBT8 & 100.0 & 57.8 & 42.2 & 5.78 & 8.27 & 14.05 & 43.75 & $10.0 \%$ & $24.3 \%$ \\
\hline
\end{tabular}

Sample \#3, remove supernate until $12 \%$ insoluble solids

\begin{tabular}{|l|c|c|c|c|c|c|c|c|c|}
\hline & $\begin{array}{c}\text { Initital } \\
\text { Mass, } \\
\mathrm{g}\end{array}$ & $\begin{array}{c}\text { Final } \\
\text { Mass, } \\
\mathrm{g}\end{array}$ & $\begin{array}{c}\text { Removed } \\
\text { Supernate }\end{array}$ & $\begin{array}{c}\text { Insoluble } \\
\text { Solids } \\
\text { Mass, g }\end{array}$ & $\begin{array}{c}\text { Soluble } \\
\text { Solids } \\
\text { Mass, g }\end{array}$ & $\begin{array}{c}\text { Total } \\
\text { Solids, g }\end{array}$ & $\begin{array}{c}\text { Water } \\
\text { Mass, g }\end{array}$ & $\begin{array}{c}\text { Insoluble } \\
\text { Solids, } \\
\text { wt \% }\end{array}$ & $\begin{array}{c}\text { Total } \\
\text { Solids, } \\
\text { wt \% }\end{array}$ \\
\hline SBT1 & 100.0 & 54.92 & 45.08 & 6.59 & 7.53 & 14.12 & 40.80 & $12.0 \%$ & $25.7 \%$ \\
\hline SBT6 & 100.0 & 62.25 & 37.75 & 7.47 & 8.50 & 15.97 & 46.28 & $12.0 \%$ & $25.6 \%$ \\
\hline SBT7 & 100.0 & 49.58 & 50.42 & 5.95 & 6.67 & 12.62 & 36.96 & $12.0 \%$ & $25.5 \%$ \\
\hline SBT8 & 100.0 & 48.17 & 51.83 & 5.78 & 6.74 & 12.52 & 35.65 & $12.0 \%$ & $26.0 \%$ \\
\hline
\end{tabular}

Sample \#4, remove supernate to $15 \%$ insoluble solids

\begin{tabular}{|l|c|l|l|c|c|c|c|c|c|}
\hline & $\begin{array}{c}\text { Initital } \\
\text { Mass, } \\
\mathrm{g}\end{array}$ & $\begin{array}{l}\text { Final } \\
\text { Mass, } \\
\mathrm{g}\end{array}$ & $\begin{array}{l}\text { Removed } \\
\text { Supernate }\end{array}$ & $\begin{array}{l}\text { Insoluble } \\
\text { Solids } \\
\text { Mass, g }\end{array}$ & $\begin{array}{l}\text { Soluble } \\
\text { Solids } \\
\text { Mass, g }\end{array}$ & $\begin{array}{l}\text { Total } \\
\text { Solids, g }\end{array}$ & $\begin{array}{l}\text { Water } \\
\text { Mass, g }\end{array}$ & $\begin{array}{l}\text { Insoluble } \\
\text { Solids, } \\
\text { wt \% }\end{array}$ & $\begin{array}{c}\text { Total } \\
\text { Solids, } \\
\text { wt } \%\end{array}$ \\
\hline SBT1 & 100.0 & 43.93 & 56.07 & 6.59 & 5.82 & 12.41 & 31.53 & $15.0 \%$ & $28.2 \%$ \\
\hline SBT6 & 100.0 & 49.80 & 50.20 & 7.47 & 6.57 & 14.03 & 35.77 & $15.0 \%$ & $28.2 \%$ \\
\hline SBT7 & 100.0 & 39.67 & 60.33 & 5.95 & 5.16 & 11.11 & 28.56 & $15.0 \%$ & $28.0 \%$ \\
\hline SBT8 & 100.0 & 38.53 & 61.47 & 5.78 & 5.21 & 10.99 & 27.55 & $15.0 \%$ & $28.5 \%$ \\
\hline
\end{tabular}


WSRC-TR-2005-00294

Revision 0

This page intentionally left blank. 


\subsection{RESULTS AND DISCUSSION}

The data from the testing and any observations will be discussed in this section. This section has been divided into five subsections. Section 3.1 discusses the analyses of the starting sludges and the necessary inputs for the acid calculation. Section 3.2 discusses the general observations about processing and the $\mathrm{pH}$ profiles. Section 3.3 discusses the SRAT product characterization. Section 3.4 discusses the SRAT product rheology. Finally, section 3.5 discusses the SRAT product particle size.

\subsection{Starting Sludge Composition}

Eight sludge batches were produced in FY04 in an attempt to produce a simulant that more closely matched the rheological properties of the actual sludge. ${ }^{2}$ Note that these sludges were significantly lower in insoluble solids than the actual waste. This was the result of the slow settling of the insoluble solids using gravity settling. The actual waste was $14.8 \mathrm{wt} \%$ insoluble solids and the simulants were 6.9 to $8.0 \mathrm{wt} \%$.

The baseline sludge (Test 1) and the three best sludges (Test 6,7, and 8) were chosen for this testing (best sludges were chosen based on having similar rheology to actual SB3 sludge). Table 3-1 presents the analysis of the feeds used in this study. Noble metals are routinely added directly to the SRAT vessel rather than in the sludge makeup because they are present in small quantities. When they are added with the sludge, rinse water is also used to ensure that all chemicals and the sludge have been transferred. No samples of the sludge simulant after trimming (i.e., "receipt" samples) were taken in this study, since the only difference between the "sludge" and "receipt" sample was the addition of noble metals, mercury, and water, very little difference was expected in the analytical results and the changes could be calculated based on the known addition amounts. Rinse water would later be removed with the dewater amount during concentration. 
WSRC-TR-2005-00294

Revision 0

Table 3-1: Sludge Simulant Analyzed Compositions

\begin{tabular}{|c|c|c|c|c|}
\hline Sludge Feed ID & $\begin{array}{l}\text { ISPM-T1 } \\
\text { Baseline }\end{array}$ & ISPM-T6 & ISPM-T7 & ISPM-T8 \\
\hline \multicolumn{4}{|c|}{ Elemental (wt\% in calcined solids) } & \\
\hline Al & 7.89 & 7.77 & 6.24 & 6.63 \\
\hline $\mathbf{B a}$ & 0.050 & 0.050 & 0.044 & 0.045 \\
\hline $\mathbf{C a}$ & 2.31 & 2.21 & 2.24 & 2.08 \\
\hline $\mathbf{C r}$ & 0.194 & 0.112 & 0.1015 & 0.108 \\
\hline $\mathbf{C u}$ & 0.032 & 0.031 & 0.038 & 0.031 \\
\hline $\mathbf{F e}$ & 20.3 & 20.4 & 19.6 & 19.5 \\
\hline $\mathbf{K}$ & 0.266 & 0.264 & 0.316 & 0.220 \\
\hline Mg & 1.84 & 1.78 & 1.725 & 1.705 \\
\hline Mn & 4.37 & 4.31 & 4.07 & 4.17 \\
\hline $\mathbf{N a}$ & 23.4 & 23.4 & 24.3 & 24.0 \\
\hline $\mathbf{N i}$ & 1.12 & 1.10 & 1.06 & 1.04 \\
\hline $\mathbf{P}$ & 0.693 & 0.698 & 0.731 & 0.773 \\
\hline $\mathbf{P b}$ & $<0.010$ & 0.014 & 0.019 & 0.022 \\
\hline $\mathbf{S}$ & 0.452 & 0.454 & 0.445 & 0.256 \\
\hline Si & 0.478 & 0.443 & 0.411 & 0.415 \\
\hline $\mathbf{T i}$ & 0.022 & 0.021 & 0.015 & 0.013 \\
\hline Zn & 0.037 & 0.035 & 0.0315 & 0.0315 \\
\hline $\mathbf{Z r}$ & $<0.010$ & $<0.010$ & $<0.010$ & $<0.010$ \\
\hline \multicolumn{5}{|c|}{ Anions ( $\mathrm{mg} / \mathrm{kg}$ in slurry) } \\
\hline $\mathrm{NO}_{2}^{-}$ & 16400 & 16500 & 16500 & 16600 \\
\hline $\mathrm{NO}_{3}^{-}$ & 11450 & 11650 & 11500 & 12350 \\
\hline $\mathrm{Cl}^{-}$ & 205 & 207 & 208 & 206 \\
\hline $\mathrm{SO}_{4}{ }^{2-}$ & 1650 & 1670 & 1680 & 949 \\
\hline $\mathrm{C}_{2} \mathrm{O}_{4}{ }^{2-}$ & 970 & 985 & 990 & 992 \\
\hline \multicolumn{5}{|c|}{ Physical Properties } \\
\hline ACTL Total Solids (wt \%) & $15.37 \%$ & $15.11 \%$ & $15.23 \%$ & $15.13 \%$ \\
\hline ACTL Insoluble Solids (wt \%) & $7.99 \%$ & $7.56 \%$ & $7.32 \%$ & $6.85 \%$ \\
\hline ACTL Soluble Solids (wt \%) & $7.39 \%$ & $7.56 \%$ & $7.91 \%$ & $8.28 \%$ \\
\hline Calcined Solids (wt \%) & $11.02 \%$ & $10.81 \%$ & $9.85 \%$ & $9.86 \%$ \\
\hline ACTL Density (g/ml) & 1.12 & 1.12 & 1.12 & 1.12 \\
\hline pH & 12.09 & 11.96 & 11.83 & 12.1 \\
\hline ADS TIC (mg/kg) & 1640 & 2180 & 1770 & 2170 \\
\hline Base Equivalents at pH 7 (Eq/L) & 0.714 & 0.601 & 0.700 & 0.649 \\
\hline Calcine Factor & 0.733 & 0.723 & 0.697 & 0.695 \\
\hline
\end{tabular}


The acid calculation was performed using the "sludge" analysis data given in Table 3-2. The acid calculation used the average value of nitrite and nitrate for the four sludges. In addition, the Mn result was divided by the calcine factor in each of the acid equation spreadsheets. For example, the measured Mn for Run ISPMT1 was $4.370 \mathrm{wt} \% \mathrm{Mn}$ on a total solids basis (or $5.965 \mathrm{wt} \% \mathrm{Mn}$ on a calcined solids basis) but $5.965 \mathrm{wt} \%$ Mn on a total solids basis was used in the acid spreadsheet. This led to the addition of $161.3-162.0 \%$ acid, approximately $4 \%$ higher than the target.

Table 3-2: Pre-Run Measured Inputs and Assumptions for Acid Calculation

\begin{tabular}{|c|c|c|c|c|}
\hline Input Parameter & $\begin{array}{c}\text { ISPM-T1 } \\
\text { Baseline }\end{array}$ & ISPM-T6 & ISPM-T7 & ISPM-T8 \\
\hline Nitrite (mg/kg) & 16,500 & 16,500 & 16,500 & 16,500 \\
\hline Nitrate (mg/kg) & 11,738 & 11,738 & 11,738 & 11,738 \\
\hline Oxalate (mg/kg) & 970 & 985 & 990 & 992 \\
\hline TIC (mg/kg) & 1640 & 2180 & 1770 & 2170 \\
\hline Base Eqv. (M) & 0.714 & 0.601 & 0.684 & 0.647 \\
\hline Mn used in acid calc (wt\% in total solids) & 5.965 & 5.959 & 5.843 & 6.003 \\
\hline Actual Mn (wt\% in total solids) & 4.370 & 4.310 & 4.070 & 4.170 \\
\hline Total Solids (wt \%) & 15.37 & 15.11 & 15.23 & 15.12 \\
\hline Density (g/ml) & 1.122 & 1.120 & 1.121 & 1.122 \\
\hline Calcine Factor & 0.733 & 0.723 & 0.697 & 0.695 \\
\hline Hg (\% in Total Solids) & $0.00 \%$ & $0.00 \%$ & $0.00 \%$ & $0.00 \%$ \\
\hline Nitrite to Nitrate Conversion & 30.00 & 30.00 & 30.00 & 30.00 \\
\hline Formate Destruction & 13.00 & 13.00 & 13.00 & 13.00 \\
\hline Sludge Simulant Mass (g) & 785.40 & 785.40 & 785.40 & 785.40 \\
\hline Acid Stoichiometry & $155 \%$ & $155 \%$ & $155 \%$ & $155 \%$ \\
\hline Recalculated Acid Stoichiometry & $161.3 \%$ & $161.5 \%$ & $162.0 \%$ & $162.0 \%$ \\
\hline Redox Target & 0.200 & 0.200 & 0.200 & 0.200 \\
\hline Ratio of Formic to Nitric & 0.8564 & 0.8573 & 0.8570 & 0.8544 \\
\hline Mol Acid/Liter of Slurry & 2.2801 & 2.2543 & 2.2604 & 2.3253 \\
\hline
\end{tabular}

\subsection{SRAT Processing}

The SRAT runs were performed simultaneously in two different hoods at the ACTL in the 2-liter vessels. The SRAT cycles were initiated after the trim chemicals were added. Nitric acid was added first and then formic acid. After the completion of acid addition, the vessel was ramped to boiling. Once boiling was initiated, the SRAT was refluxed for 12 hours. Dewatering of the SRAT contents was completed after the 12 hour reflux was complete to bring the sludge to the target solids concentration. The dewater time was very short, as reflected in Table A - 2.

Overall mass balance closure was poor for the runs (within $200 \mathrm{~g}$ on a mass basis) compared with other runs at this scale. The bulk of the material balance deficit was probably contained in lost water vapor, solid 
deposits on the SRAT vessel and in the offgas non-condensable species $\left(\mathrm{O}_{2}, \mathrm{CO}_{2}, \mathrm{NO}, \mathrm{NO}_{2}, \mathrm{~N}_{2} \mathrm{O}\right.$, and $\left.\mathrm{H}_{2}\right)$. Larger mass losses tend to invalidate calculations on nitrite to nitrate conversion and formate loss.

Mixing and heating of the slurries during the SRAT cycles were not an issue. No problems with foaming or processing of the slurries were evident. No additional antifoam was added to cover the DWPF amount added between acid additions. No other problems were seen during the runs.

The $\mathrm{pH}$ was measured throughout the runs. Figure 3-1 is a plot of the measured pH during the SRAT cycle. There was excellent agreement between all four runs from $\mathrm{pH} 9$ to 4 . However, two of the SRAT runs had a temporary reversal in the $\mathrm{pH}$ trend between $\mathrm{pH} 11$ and $\mathrm{pH}$ 9. The only consistent difference between these tests was that the tests with the reversal (Test 1 and Test 6) had aluminum added as the oxide after washing while the tests without the reversal had the aluminum co-precipitated at the start of sludge preparation.

Figure 3-1: pH Plots for All Runs

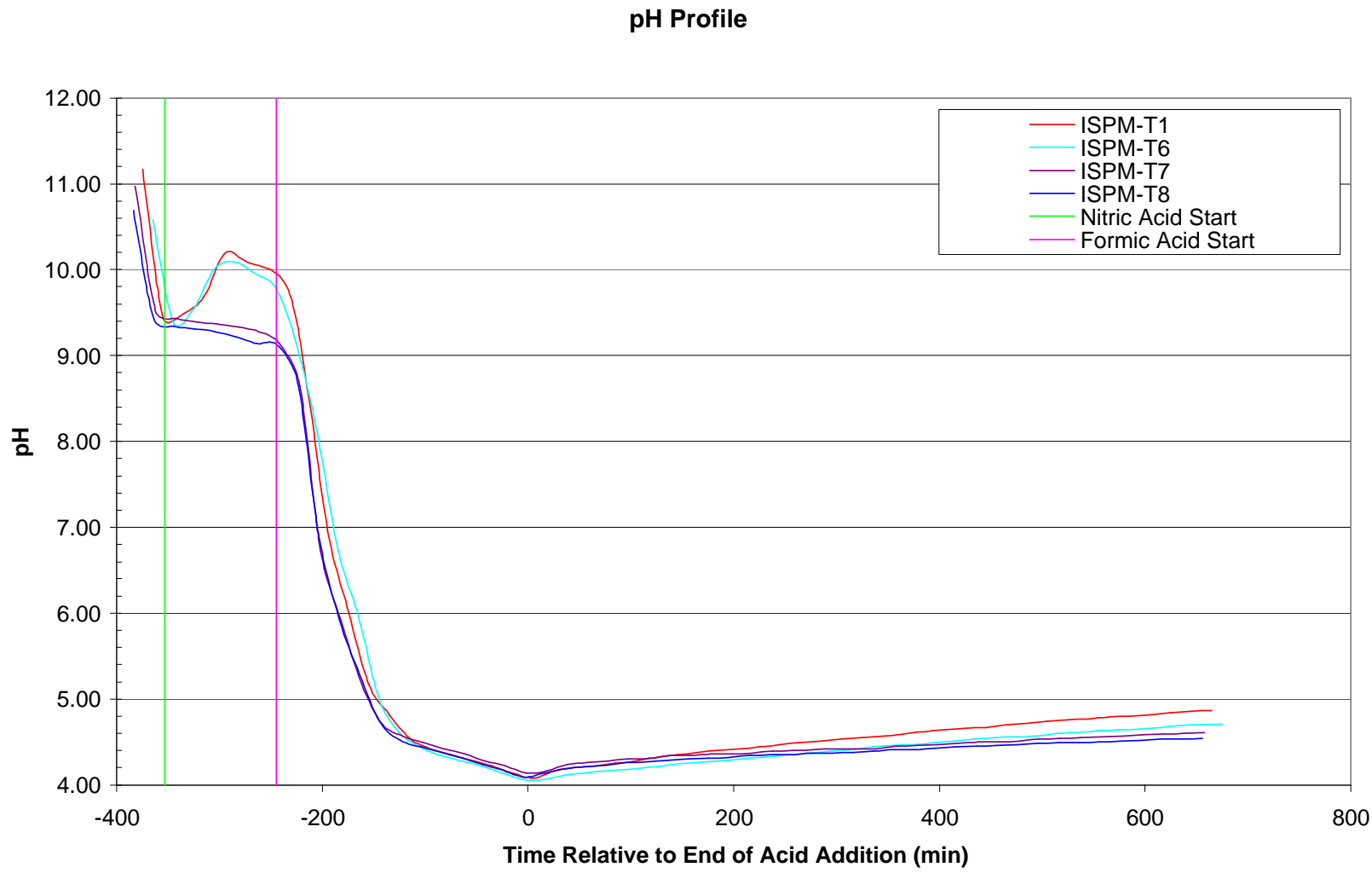

\subsection{SRAT Product Chemical Analyses}

The SRAT product from each run was characterized for the anion concentration, cation concentration, solids content, density, and $\mathrm{pH}$. The product anion concentration for each run is given in Table 3-3. 
Table 3-3: SRAT Product Anion Concentration (mg/kg)

\begin{tabular}{||c|c|c|c||}
\hline Anion & Nitrite & Nitrate & Formate \\
\hline ISPM-T1 & $<100$ & 37,100 & 72,950 \\
\hline ISPM-T6 & $<100$ & 40,950 & 69,550 \\
\hline ISPM-T7 & $<100$ & 36,850 & 78,450 \\
\hline ISPM-T8 & $<100$ & 38,900 & 77,700 \\
\hline
\end{tabular}

Note: Analyses performed on weighted dilution of samples.

Results represent an average of two measurements.

The percent conversion of nitrite to nitrate and percent destruction of formate during the SRAT process is given in Table 3-4. The conversions/destructions are calculated based on the amount of nitrite, nitrate, and formate in the simulant and added during processing versus the amount that is present in the SRAT product. The calculation of the formate destruction and especially the nitrate conversion is strongly impacted by the mass balance closure for each run. For example, if the mass balance indicates there is more final product than was added based on known additions, the nitrate conversion will be higher than is reasonable. As a result, the nitrite to nitrate conversion is much higher than the prediction for runs T6 and T8 and the formate conversion is lower than predicted for run T8. As a result, for runs T6 and T8 the nitrite to nitrate conversion is less than the predictions and the formate conversion may be more than the prediction. The concentrations of the actual nitrate, nitrite, and formate indicate that the formate destruction and nitrite to nitrate conversion is similar in all four runs.

Table 3-4: Formate Destruction, Nitrate Conversion - SRAT Receipt Relative to SRAT Product

\begin{tabular}{||l|l|l|l|c|c|c||}
\hline \multirow{2}{*}{ Run ID } & \multirow{2}{*}{$\%$ Acid } & \multirow{2}{*}{ Hg Present } & \multicolumn{2}{|c|}{$\begin{array}{c}\text { \% Formate } \\
\text { Destruction }\end{array}$} & \multicolumn{2}{c|}{$\begin{array}{c}\text { Nitrite to Nitrate } \\
\text { Conversion }\end{array}$} \\
\cline { 4 - 7 } & & & Predicted & Measured & Predicted & Measured \\
\hline ISPM-T1 & 161.3 & No & 13 & 12.0 & 30 & 32.0 \\
\hline ISPM-T6 & 161.5 & No & 13 & 11.1 & 30 & 59.2 \\
\hline ISPM-T7 & 162.0 & No & 13 & 13.3 & 30 & 15.7 \\
\cline { 3 - 7 } ISPM-T8 & 162.0 & No & 13 & 0.8 & 30 & 58.5 \\
\hline
\end{tabular}

As mentioned in Section 2.3, the SRAT products were calcined at $1100^{\circ} \mathrm{C}$ in order to prepare them for cation analyses. The elements detected in the calcined solids are given in Table 3-5. 
Table 3-5: SRAT Product Results (Calcined Solids Wt \%)

\begin{tabular}{||c|c|c|c|c||}
\hline Sludge Feed ID & $\begin{array}{c}\text { ISPM-T1 } \\
\text { Baseline }\end{array}$ & ISPM-T6 & ISPM-T7 & ISPM-T8 \\
\hline $\mathbf{A l}$ & 5.46 & 6.53 & 5.77 & 6.14 \\
\hline $\mathbf{B a}$ & 0.05 & 0.04 & 0.04 & 0.04 \\
\hline $\mathbf{C a}$ & 2.11 & 1.80 & 1.84 & 1.86 \\
\hline $\mathbf{C r}$ & 0.20 & 0.12 & 0.13 & 0.13 \\
\hline $\mathbf{C u}$ & 0.01 & 0.01 & 0.02 & 0.01 \\
\hline $\mathbf{F e}$ & 21.15 & 21.30 & 18.90 & 18.95 \\
\hline $\mathbf{G d}$ & 0.06 & 0.05 & 0.06 & 0.05 \\
\hline $\mathbf{K}$ & 0.50 & 0.46 & 0.55 & 0.46 \\
\hline $\mathbf{M g}$ & 1.82 & 1.62 & 1.58 & 1.52 \\
\hline $\mathbf{M n}$ & 4.65 & 4.70 & 4.02 & 3.95 \\
\hline $\mathbf{N a}$ & 23.70 & 22.80 & 24.90 & 24.80 \\
\hline $\mathbf{N i}$ & 1.15 & 1.22 & 1.00 & 0.94 \\
\hline $\mathbf{P}$ & 0.71 & 0.69 & 0.76 & 0.76 \\
\hline $\mathbf{P b}$ & 0.03 & 0.03 & 0.03 & 0.03 \\
\hline $\mathbf{S}$ & 0.48 & 0.47 & 0.52 & 0.27 \\
\hline $\mathbf{S i}$ & 0.56 & 0.49 & 0.42 & 0.45 \\
\hline $\mathbf{T i}$ & 0.05 & 0.04 & 0.04 & 0.04 \\
\hline $\mathbf{Z n}$ & 0.02 & 0.02 & 0.02 & 0.02 \\
\hline $\mathbf{Z r}$ & 0.04 & 0.05 & 0.04 & 0.04 \\
\hline
\end{tabular}

Note: Two aliquots are removed from the product sample. Each aliquot is then calcined, dissolved, and analyzed.

Results represent an average of the two measurements. The sum of oxides for these analyses was outside the 95$105 \%$ target expected. The reason for the low sum of oxides (89.3-92.8\% is likely due to incomplete calcination or digestion. Insufficient sample was available to repeat the sample preparation and measurement.

When the SRAT product compositions are compared with the simulant compositions given in Table 3-1, most of the oxides are very similar. Overall, the compositions represented a reasonable estimation of the SB3 simulant major components.

The total and dissolved solids were measured on the SRAT products, and the insoluble and soluble solids were then calculated. As mentioned above, the calcined solids were also measured. To complete the physical property analyses, the slurry density and $\mathrm{pH}$ were measured. The results are given in Table 3-6.

Table 3-6: Physical Property Data on SRAT Products

\begin{tabular}{||l|c|c|c|c||}
\hline \hline Analysis & ISPM-T1 & ISPM-T6 & ISPM-T7 & ISPM-T8 \\
\hline Slurry Total Solids, wt \% & 21.14 & 21.83 & 20.33 & 20.76 \\
\hline Insoluble Solids, wt \% & 6.59 & 7.47 & 5.95 & 5.78 \\
\hline Soluble Solids, wt \% & 14.55 & 14.35 & 14.38 & 14.98 \\
\hline Density, g/mL & 1.156 & 1.162 & 1.151 & 1.154 \\
\hline Filtrate Solids, wt \% & 15.58 & 15.51 & 15.29 & 15.90 \\
\hline pH & 4.94 & 4.81 & 4.71 & 4.62 \\
\hline
\end{tabular}

Note: Measured on two aliquots from the same sample. Data reported is an average. Total and dissolved solids were actually measured and insoluble and soluble solids were calculated. 


\subsection{SRAT Product Rheology}

SRAT product samples at four levels of insoluble solids (as received, 10\%, 12\% and 15\%) were produced by removing supernate from $100 \mathrm{~g}$ SRAT product samples. The as received SRAT products were rheologically thin, so no dilution of the samples was warranted. The target for each of the samples is discussed in section 2.4. The results of the preparation of these samples relative to the target are reported in section 3.4.1. The rheological results are reported in section 3.4.2 and Appendix A. Note that several of the targets could not be reached due to inadequate gravity settling of the samples.

\subsubsection{Rheology Sample Preparation}

The concentrated SRAT samples were prepared by removing supernate (soluble solids plus water) from the original slurry after concentrating through gravity settling. Two of the samples required additional concentration by centrifuging for three minutes (Test 1 and Test 8 SRAT Products targeting 15 wt \% insoluble solids) at $500 \mathrm{rpm}$ using an IEC Centra GP8 centrifuge. The resultant concentrated slurry had the same mass of insoluble solids as the original slurry, assuming no insoluble solids were removed. The concentrated samples were analyzed for total solids. The insoluble solids concentration was calculated from the previously analyzed supernate solids analysis. The calculated removal of supernate from the original SRAT products to produce the sixteen concentrated rheology samples is summarized in Table 3-7. Note that the measured total solids were within $5 \%$ of the target for all samples.

Table 3-7: Preparation of Concentrated SRAT Products

\begin{tabular}{|c|c|c|c|c|c||}
\hline $\begin{array}{c}\text { Rheology } \\
\text { Sample }\end{array}$ & $\begin{array}{c}\text { Predicted } \\
\text { Total } \\
\text { Solids, } \\
\text { wt\% }\end{array}$ & $\begin{array}{c}\text { Measured } \\
\text { Total } \\
\text { Solids, } \\
\text { wt\% }\end{array}$ & $\begin{array}{c}\text { Initial } \\
\text { Slurry, g }\end{array}$ & $\begin{array}{c}\text { Removed } \\
\text { Supernate, } \\
\text { g }\end{array}$ & Final Slurry, g \\
\hline ISPM-T1-as is* & $21.14 \%$ & $21.14 \%$ & 100.00 & 0.00 & 100.00 \\
\hline ISPM-T1-10\% & $24.02 \%$ & $24.49 \%$ & 100.00 & 34.10 & 65.90 \\
\hline ISPM-T1-12\% & $25.31 \%$ & $25.81 \%$ & 100.00 & 42.85 & 57.15 \\
\hline ISPM-T1-15\% & $26.96 \%$ & $28.28 \%$ & 100.00 & 51.15 & 48.86 \\
\hline ISPM-T6-as is & $21.82 \%$ & $21.82 \%$ & 100.00 & 0.00 & 100.00 \\
\hline ISPM-T6-10\% & $23.96 \%$ & $23.68 \%$ & 100.00 & 25.31 & 74.69 \\
\hline ISPM-T6-12\% & $25.65 \%$ & $25.41 \%$ & 100.00 & 37.75 & 62.25 \\
\hline ISPM-T6-15\% & $28.18 \%$ & $28.25 \%$ & 100.00 & 50.20 & 49.80 \\
\hline ISPM-T7-as is & $20.33 \%$ & $20.33 \%$ & 100.00 & 0.00 & 100.00 \\
\hline ISPM-T7-10\% & $23.76 \%$ & $24.06 \%$ & 100.00 & 40.50 & 59.50 \\
\hline ISPM-T7-12\% & $25.45 \%$ & $25.58 \%$ & 100.00 & 50.42 & 49.59 \\
\hline ISPM-T7-15\% & $27.89 \%$ & $28.38 \%$ & 100.01 & 59.99 & 40.01 \\
\hline ISPM-T8-as is & $20.76 \%$ & $20.76 \%$ & 100.00 & 0.00 & 100.00 \\
\hline ISPM-T8-10\% & $24.31 \%$ & $24.42 \%$ & 100.00 & 42.20 & 57.80 \\
\hline ISPM-T8-12\% & $25.99 \%$ & $26.31 \%$ & 100.00 & 51.82 & 48.18 \\
\hline ISPM-T8-15\% & $28.52 \%$ & $29.01 \%$ & 100.00 & 61.47 & 38.53 \\
\hline
\end{tabular}

"as is" is equivalent to as received

\subsubsection{Rheology Results}

Rheological analyses of all of the SRAT products were performed at a minimum in duplicate. Appendix B presents the flow curves and the individual and averaged Bingham Plastic yield stress and plastic viscosity determined using the Bingham Plastic rheological model. All of the products at low wt \% insoluble solids content were visually and rheologically thin, and only minor differences were observed for product and feed slurries. 
The flow curves for the low wt $\%$ insoluble solids products showed that the material was initially nearly Newtonian in fluid properties shifting to increasingly non-Newtonian as the solids loading increased. At a solids loading of $12 \mathrm{wt} \%$ and higher, the samples began to show thixotropic fluid properties (thinning with time under shear). Figure 3-2 shows an example of flow curves for nominally 10 and $12 \mathrm{wt} \%$ insoluble solids SRAT products produced from the Test 7 sludge. The up and down portion of the flow curve for the $10 \mathrm{wt} \%$ insoluble solids sample show a very small separation while the $12 \mathrm{wt} \%$ insoluble solids sample shows substantial shear thinning. All of the SRAT products at the highest insoluble solids loading showed an even greater thixotropic behavior.

\section{Figure 3-2: ISPM-T7 SRAT Product Flow Curves}

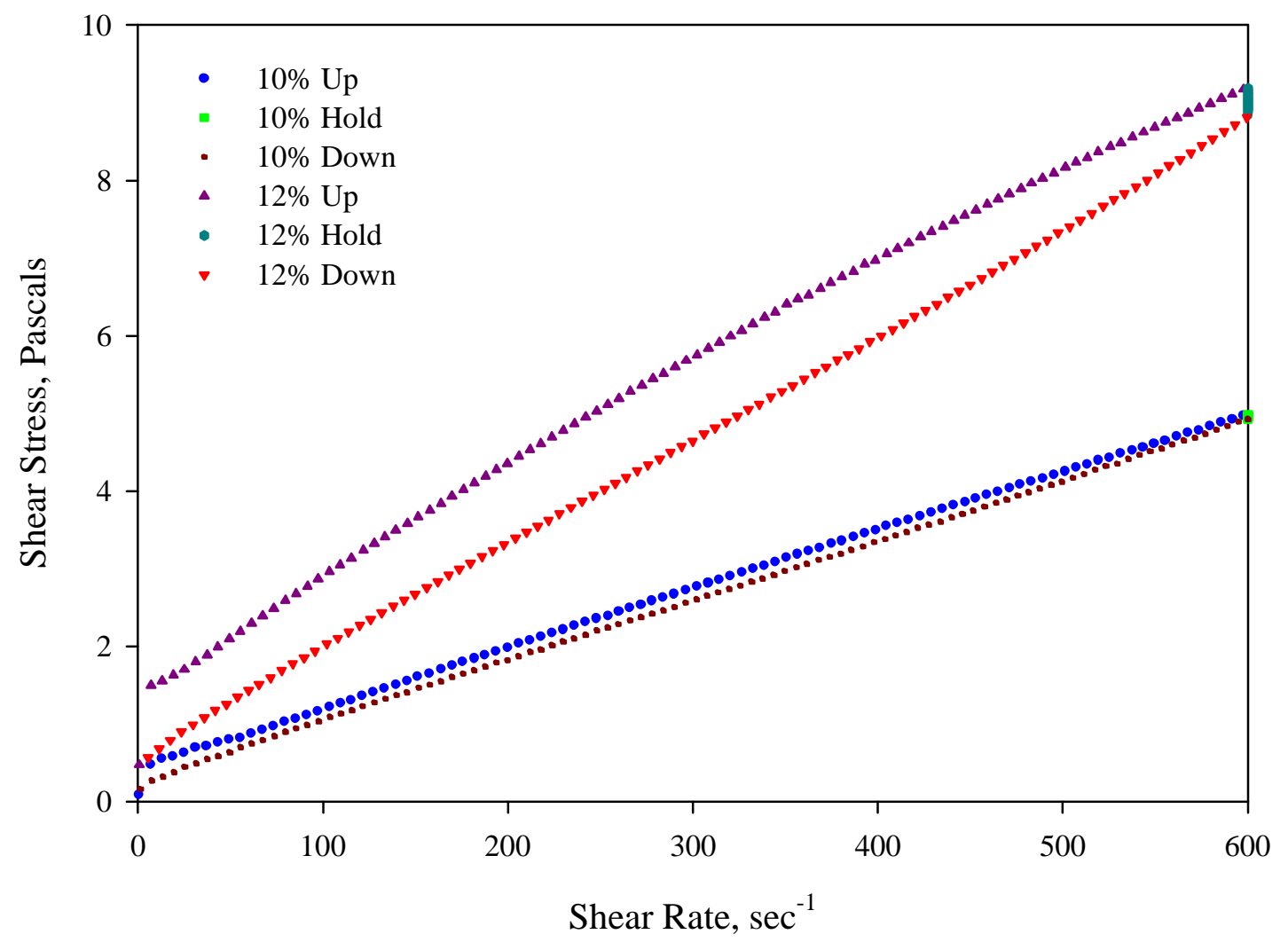

In order to properly represent the properties before and after shearing, the results for the linear regression of the Bingham equation on the up and down flow curves are reported separately in Appendix B. The down flow curve represents the sheared SRAT material and is the normal operating regime for the SRAT product (continuous agitation). The up flow curve represents the unsheared SRAT product and would be typical of an abnormal (such as restart after layup) condition for the SRAT process.

The as received and concentrated rheological analyses were performed by PSE technicians at ACTL. The rheology analyses are summarized in Table 3-9 and Table 3-10. The Bingham Plastic yield stress data (individual data points and average line) are graphed in Figure 3-3 and Figure 3-4. The plastic viscosity data (individual and average) are graphed in Figure 3-5 and Figure 3-6. The more concentrated samples had the highest yield stress values. The average yield stress at $15 \mathrm{wt} \%$ insoluble solids ranged from 2.96-6.64 Pa or 29.6-66.4 dynes $/ \mathrm{cm}^{2}$ for the sheared samples (down flow curves) and 9.11-21.45 Pa or 91.1-214.5 dynes $/ \mathrm{cm}^{2}$ for the unsheared samples (up flow curves). The highest yield stress for a sheared sample was for the $15 \mathrm{wt}$ 
\% SRAT product from Test 8. The plastic viscosity at $15 \mathrm{wt} \%$ insoluble solids ranged from 19.4-28.8 $\mathrm{cp}$. The highest plastic viscosity was for the $15 \mathrm{wt} \%$ SRAT product from Test 8 . Note that ISPM-T8 had a very sharp increase in yield stress from $12 \%$ to $15 \%$ for the sheared data, while that magnitude of increase was not seen in the other three experiments for the sheared data. All of the unsheared samples showed a sharp increase in yield stress at the highest solids loading.

Flow curve phenomena similar to those seen with Sludge Batch 2 simulant sludge slurry were seen in many of these SRAT products. The earlier behavior was examined in detail by Koopman ${ }^{10}$. These included a complex behavior (structural breakdown) during the initial ramp of shear rate from zero to the maximum shear rate. The down curve data was linearly regressed using the Bingham Plastic model, since the down curves were more nearly linear and would be the appropriate parameters for slurry in a fully-developed steady shear flow (normal SRAT operation).

Table 3-8: Physical Property Data on Sheared SRAT Products

\begin{tabular}{|c|c|cc|c|c|c|}
\hline Run & $\begin{array}{c}\text { Total } \\
\text { Mass, g }\end{array}$ & $\begin{array}{c}\text { Water } \\
\text { Mass, } \\
\mathrm{g}\end{array}$ & $\begin{array}{c}\text { Total } \\
\text { Solids, g }\end{array}$ & $\begin{array}{c}\text { Soluble } \\
\text { Solids, g }\end{array}$ & $\begin{array}{c}\text { Insoluble } \\
\text { Solids, g }\end{array}$ & $\begin{array}{c}\% \\
\text { Insoluble } \\
\text { Solids }\end{array}$ \\
\hline ISPM-T1-asis & 100.00 & 78.86 & 21.14 & 14.55 & 6.59 & $6.59 \%$ \\
\hline ISPM-T1-10\% & 65.90 & 49.76 & 16.14 & 9.18 & 6.96 & $10.56 \%$ \\
\hline ISPM-T1-12\% & 57.15 & 42.40 & 14.75 & 7.82 & 6.93 & $12.12 \%$ \\
\hline ISPM-T1-15\% & 48.86 & 35.04 & 13.82 & 6.47 & 7.35 & $15.05 \%$ \\
\hline ISPM-T6-asis & 100.00 & 78.18 & 21.82 & 14.35 & 7.47 & $7.47 \%$ \\
\hline ISPM-T6-10\% & 74.69 & 57.01 & 17.69 & 10.46 & 7.22 & $9.67 \%$ \\
\hline ISPM-T6-12\% & 62.25 & 46.43 & 15.82 & 8.52 & 7.29 & $11.72 \%$ \\
\hline ISPM-T6-15\% & 49.80 & 35.73 & 14.07 & 6.56 & 7.51 & $15.08 \%$ \\
\hline ISPM-T7-asis & 100.00 & 79.67 & 20.33 & 14.38 & 5.95 & $5.95 \%$ \\
\hline ISPM-T7-10\% & 59.50 & 45.19 & 14.32 & 8.16 & 6.16 & $10.35 \%$ \\
\hline ISPM-T7-12\% & 49.59 & 36.90 & 12.68 & 6.66 & 6.02 & $12.15 \%$ \\
\hline ISPM-T7-15\% & 40.01 & 28.66 & 11.36 & 5.17 & 6.18 & $15.45 \%$ \\
\hline ISPM-T8-asis & 100.00 & 79.24 & 20.76 & 14.98 & 5.78 & $5.78 \%$ \\
\hline ISPM-T8-10\% & 57.80 & 43.68 & 14.11 & 8.26 & 5.86 & $10.13 \%$ \\
\hline ISPM-T8-12\% & 48.18 & 35.50 & 12.68 & 6.71 & 5.96 & $12.38 \%$ \\
\hline ISPM-T8-15\% & 38.53 & 27.35 & 11.18 & 5.17 & 6.01 & $15.53 \%$ \\
\hline
\end{tabular}

"as is" is equivalent to as received 
WSRC-TR-2005-00294

Revision 0

Table 3-9: Rheology Data on Sheared SRAT Products

\begin{tabular}{|c|c|c|c|c|c|c|}
\hline Sample & $\begin{array}{c}\text { Average } \\
\text { Plastic } \\
\text { Viscosity } \\
\text { (cP) }\end{array}$ & $\begin{array}{c}\text { Average } \\
\text { Yield } \\
\text { Stress } \\
\text { (Pa) }\end{array}$ & $\begin{array}{c}\text { Predicted } \\
\text { Insoluble } \\
\text { Solids, wt\% }\end{array}$ & $\begin{array}{c}\text { Measured } \\
\text { Insoluble } \\
\text { Solids, } \\
\mathbf{w t \%}\end{array}$ & $\begin{array}{c}\text { Predicted } \\
\text { Total Solids, } \\
\mathbf{w t \%}\end{array}$ & $\begin{array}{c}\text { Measured } \\
\text { Total Solids, } \\
\text { wt\% }\end{array}$ \\
\hline ISPM-T1-asis & 4.3 & 0.56 & $6.59 \%$ & $6.59 \%$ & $21.14 \%$ & $21.14 \%$ \\
\hline ISPM-T1-10\% & 10.6 & 2.47 & $10.00 \%$ & $10.56 \%$ & $24.47 \%$ & $24.49 \%$ \\
\hline ISPM-T1-12\% & 14.3 & 3.55 & $11.53 \%$ & $12.12 \%$ & $25.97 \%$ & $25.81 \%$ \\
\hline ISPM-T1-15\% & 21.5 & 4.58 & $13.49 \%$ & $15.05 \%$ & $27.88 \%$ & $28.28 \%$ \\
\hline ISPM-T6-asis & 4.1 & 0.29 & $7.47 \%$ & $7.47 \%$ & $21.82 \%$ & $21.82 \%$ \\
\hline ISPM-T6-10\% & 6.4 & 0.78 & $10.00 \%$ & $9.67 \%$ & $24.03 \%$ & $23.68 \%$ \\
\hline ISPM-T6-12\% & 10.3 & 1.53 & $12.00 \%$ & $11.72 \%$ & $25.77 \%$ & $25.41 \%$ \\
\hline ISPM-T6-15\% & 19.4 & 2.97 & $15.00 \%$ & $15.08 \%$ & $28.39 \%$ & $28.25 \%$ \\
\hline ISPM-T7-asis & 3.2 & 0.02 & $5.95 \%$ & $5.95 \%$ & $20.33 \%$ & $20.33 \%$ \\
\hline ISPM-T7-10\% & 7.6 & 0.29 & $10.00 \%$ & $10.35 \%$ & $23.76 \%$ & $24.06 \%$ \\
\hline ISPM-T7-12\% & 13.6 & 0.60 & $12.00 \%$ & $12.15 \%$ & $25.45 \%$ & $25.58 \%$ \\
\hline ISPM-T7-15\% & 25.7 & 3.32 & $14.87 \%$ & $15.45 \%$ & $27.89 \%$ & $28.38 \%$ \\
\hline ISPM-T8-asis & 3.4 & 0.04 & $5.78 \%$ & $5.78 \%$ & $20.76 \%$ & 20.76 \\
\hline ISPM-T8-10\% & 9.0 & 0.47 & $10.00 \%$ & $10.13 \%$ & $24.31 \%$ & $24.42 \%$ \\
\hline ISPM-T8-12\% & 14.9 & 1.33 & $12.00 \%$ & $12.38 \%$ & $25.99 \%$ & $26.31 \%$ \\
\hline ISPM-T8-15\% & 28.8 & 6.64 & $15.00 \%$ & $15.53 \%$ & $28.52 \%$ & $28.96 \%$ \\
\hline
\end{tabular}

"as is" is equivalent to as initially produced

Rheological data were obtained on the SB2/3 blend SRAT cycle product made in the Shielded Cells in 2004 (C. J. Bannochie, J. M. Pareizs, and D. C. Koopman, Sludge Batch 2/3 Blend SRAT Cycle in the SRNL Shielded Cells, WSRC-TR-2004-00097, May 2004, etc.). The starting sludge for this test was very close in composition to that which formed the basis for the simulants in this study. The SRAT product was at 11.8 wt. $\%$ insoluble solids and 27.3 wt. $\%$ total solids, i.e. fairly similar to the $-12 \%$ simulant compositions above. The stoichiometric acid factor for the Shielded Cells run has been recomputed to correct for an error in one of the base equivalents titration results and for an improved value of the formic acid molarity. The revised value is $150.5 \%$, which is fairly close to the $155 \%$ target in the simulant runs.

Two flow curves were made on this sample using the RV30 rheometer in the Shielded Cells. The MV1 concentric cylinder geometry was used, which is generally similar to the Z41 geometry used in the RS600 simulant measurements. These produced a yield stress of $1.17 \mathrm{~Pa}$ and a plastic viscosity of $4.9 \mathrm{cP}$. The yield stress is essentially the same as the average of the ISPM-T6, ISPM-T7, and ISPM-T8 results. The plastic viscosity is about half as large as the ISPM-T6, ISPM-T7, and ISPM-T8 results. This is still fairly good agreement between simulant and radioactive sample. The Shielded Cells sample, however, was not thixotropic, therefore, the distinction between sheared and unsheared results for the Shielded Cells sample did not exist. 
WSRC-TR-2005-00294

Revision 0

Table 3-10: Rheology Results for Unsheared SRAT Samples

\begin{tabular}{|c|cc|c|c|}
\hline Run & $\begin{array}{c}\% \\
\text { Total } \\
\text { Solids }\end{array}$ & $\begin{array}{c}\% \\
\text { Insoluble } \\
\text { Solids }\end{array}$ & $\begin{array}{c}\text { Average } \\
\text { Plastic } \\
\text { Viscosity } \\
(\mathrm{cP})\end{array}$ & $\begin{array}{c}\text { Average } \\
\text { Yield } \\
\text { Stress } \\
(\mathrm{Pa})\end{array}$ \\
\hline ISPM-T1-asis & $21.14 \%$ & $6.59 \%$ & 4.3 & 0.60 \\
\hline ISPM-T1-10\% & $24.49 \%$ & $10.56 \%$ & 9.2 & 4.75 \\
\hline ISPM-T1-12\% & $25.81 \%$ & $12.12 \%$ & 8.0 & 8.64 \\
\hline ISPM-T1-15\% & $28.28 \%$ & $15.05 \%$ & NA* & 21.47 \\
\hline ISPM-T6-asis & $21.82 \%$ & $7.47 \%$ & 4.0 & 0.37 \\
\hline ISPM-T6-10\% & $23.68 \%$ & $9.67 \%$ & 6.3 & 0.91 \\
\hline ISPM-T6-12\% & $25.41 \%$ & $11.72 \%$ & 9.5 & 2.54 \\
\hline ISPM-T6-15\% & $28.25 \%$ & $15.08 \%$ & 10.1 & 10.64 \\
\hline ISPM-T7-asis & $20.33 \%$ & $5.95 \%$ & 2.5 & 0.39 \\
\hline ISPM-T7-10\% & $24.06 \%$ & $10.35 \%$ & 7.6 & 0.46 \\
\hline ISPM-T7-12\% & $25.58 \%$ & $12.15 \%$ & 13.0 & 1.76 \\
\hline ISPM-T7-15\% & $28.38 \%$ & $15.45 \%$ & 20.7 & 9.13 \\
\hline ISPM-T8-asis & $20.76 \%$ & $5.78 \%$ & 3.4 & 0.06 \\
\hline ISPM-T8-10\% & $24.42 \%$ & $10.13 \%$ & 8.8 & 0.79 \\
\hline ISPM-T8-12\% & $26.31 \%$ & $12.38 \%$ & 13.8 & 3.07 \\
\hline ISPM-T8-15\% & $28.96 \%$ & $15.53 \%$ & 15.9 & 18.34 \\
\hline
\end{tabular}

*Yield Stress was taken as the maximum in the curve between 0 and $100 \mathrm{sec}^{-1}$ since the curve did not properly reflect a Bingham material before shearing (i.e. the shear stress declined with increasing shear rate). Plastic viscosity could not be determined for the same reason.

"as is" is equivalent to as initially produced. 
WSRC-TR-2005-00294

Revision 0

Figure 3-3: Yield Stress as a Function of Insoluble Solids for Sheared SRAT Product

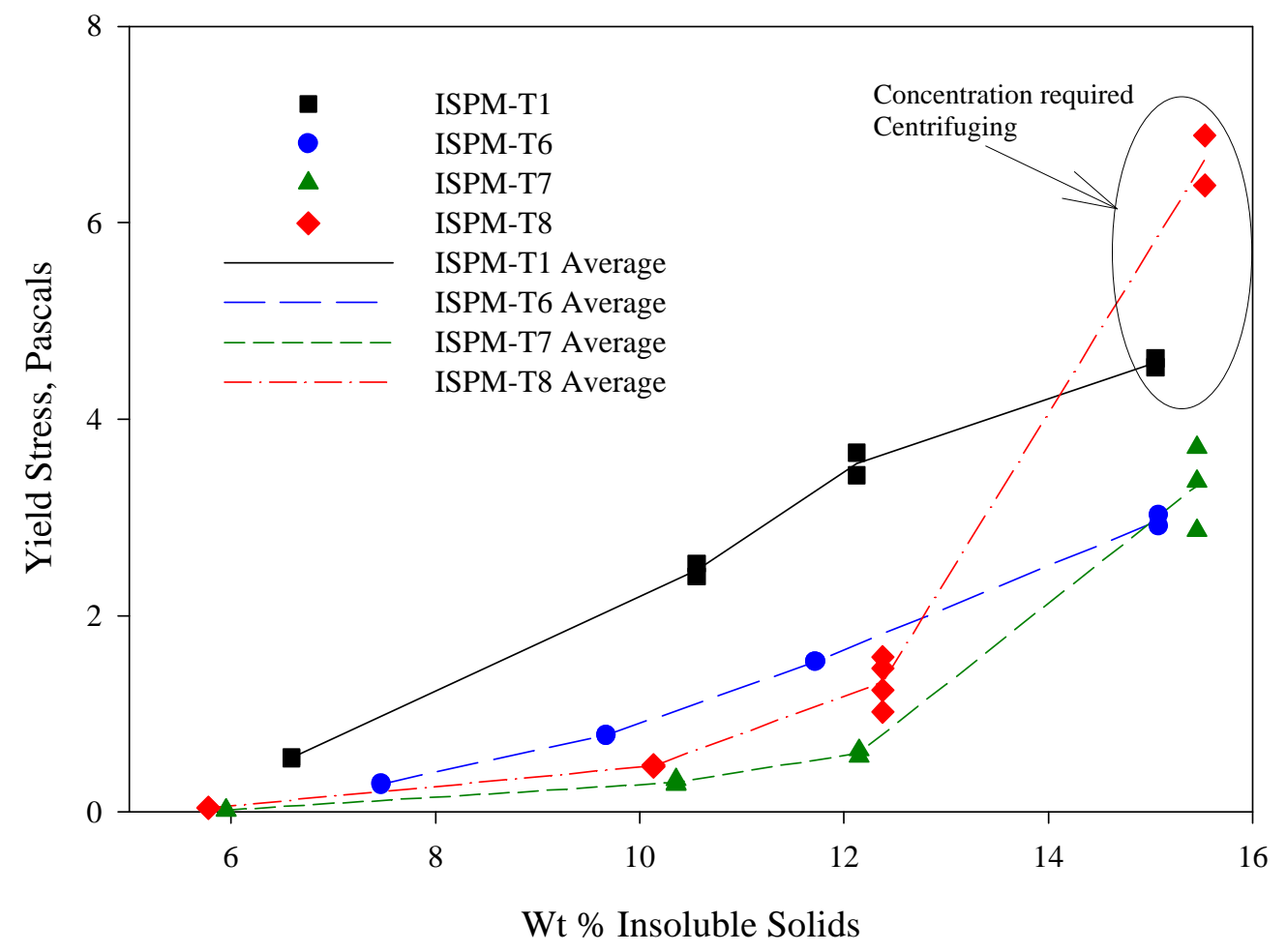

Figure 3-4: Yield Stress as a Function of Insoluble Solids for Unsheared SRAT Slurries

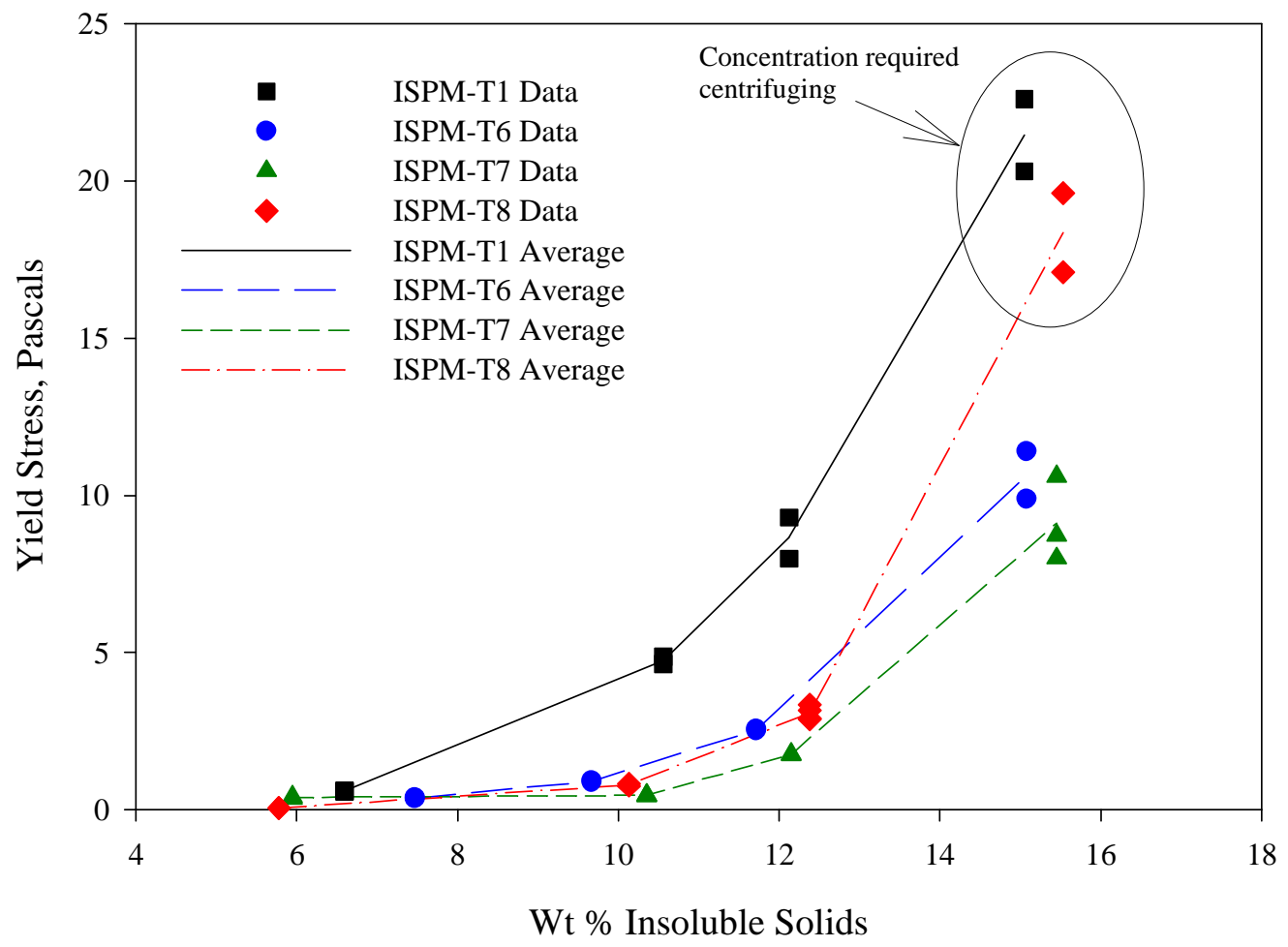


WSRC-TR-2005-00294

Revision 0

Figure 3-5: Plastic Viscosity of Sheared SRAT Product Slurries

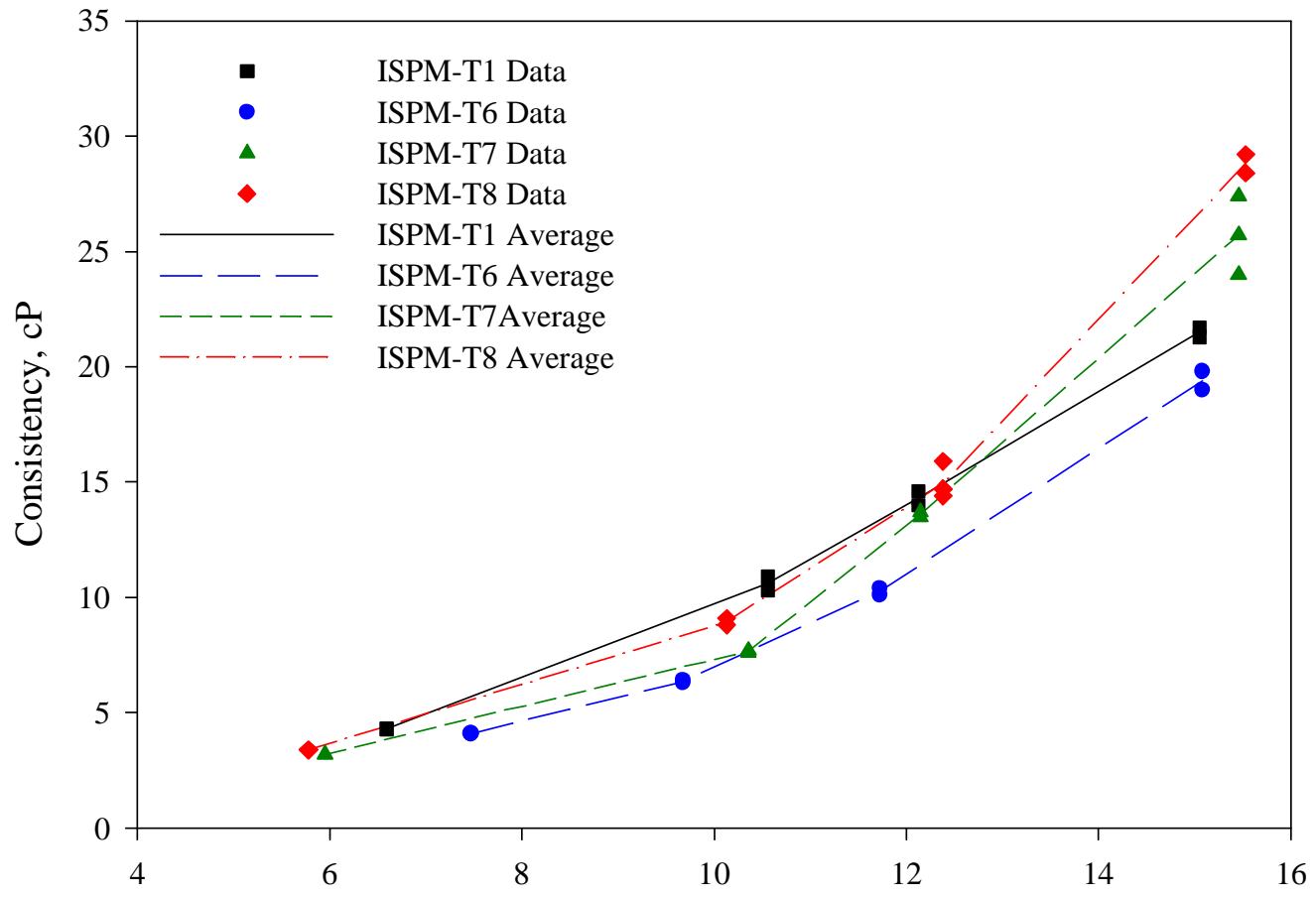

Wt \% Insoluble Solids

Figure 3-6: Plastic Viscosity for Unsheared SRAT Slurries

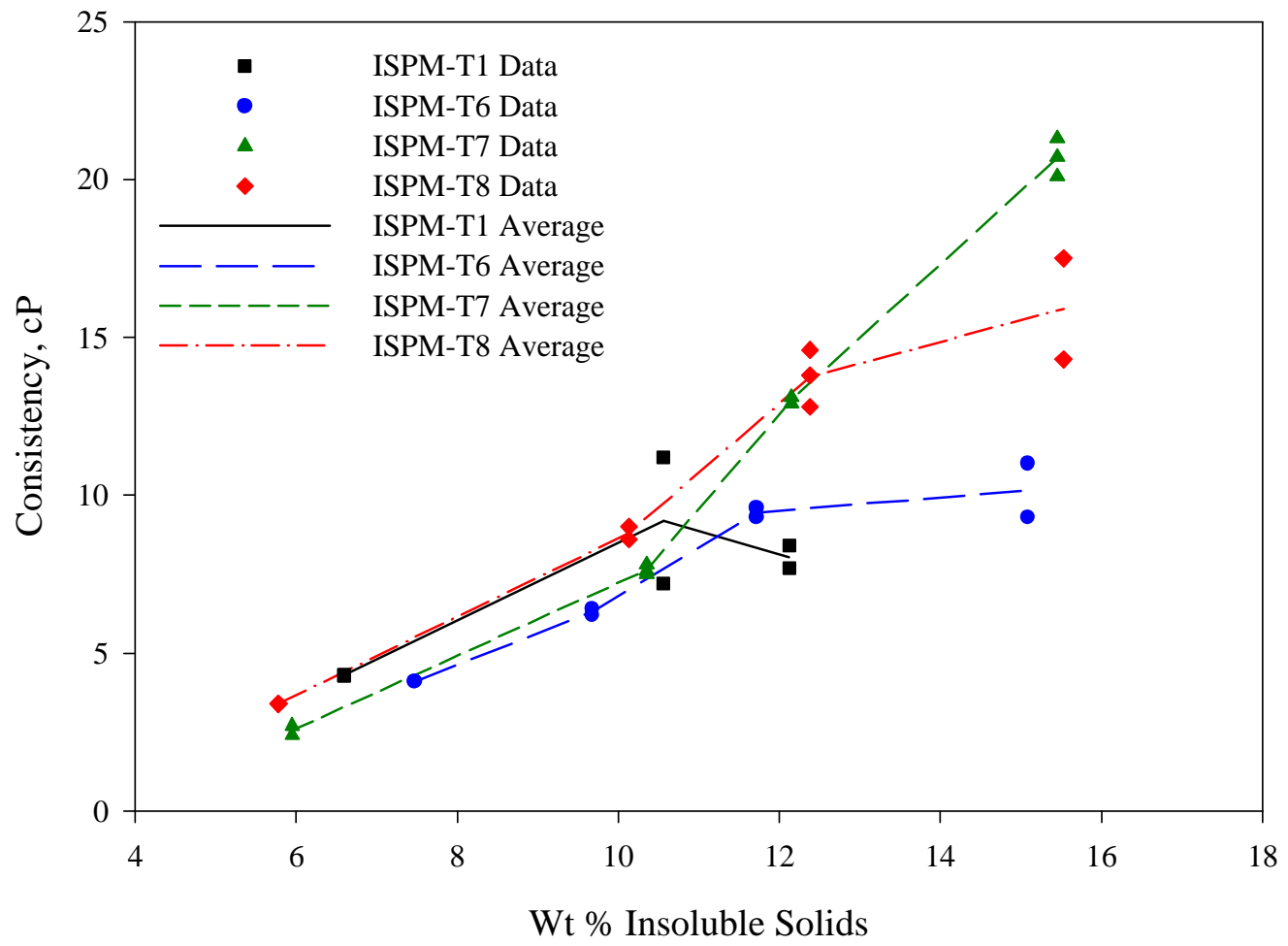


The rapid increase in yield stress observed in the SRAT product samples is typical of the rheological response of slurries to the increase of solids within those slurries. ${ }^{11}$ This rapid rise can be expressed as an exponential function of the form: ${ }^{12},{ }^{13}$

$$
Y=\frac{e^{A X}}{(1-X / B)}
$$

where $\mathrm{A}$ and $\mathrm{B}$ are independent parameters, $\mathrm{Y}$ is the viscosity and $\mathrm{X}$ is the volume fraction of the solids in the slurry. Parameter B represents the limiting amount of solids that yields a solid material instead of a fluid. Equation (6) has been extended successfully to yield stress and consistency in previous rheology studies of DPWF simulants. ${ }^{14},{ }^{15}$ Instead of the solids volume fraction, $X$ would be the weight $\%$ insoluble solids. Note that the yield stress and consistency could also be fitted to similar equations expressed in terms of weight $\%$ total solids. Application of this equation does not adequately describe the very low solids concentration region since at no solids the aqueous liquid would be expected to not have a yield stress. Therefore, the model equation was modified (eguation 7) by adding a third parameter, $\mathrm{C}$ (units in Pascals), which allows a closer match to the expected low solids rheology regime.

$$
Y=\frac{e^{A X}}{(1-X / B)}-C
$$

An alternative approach was considered that replaced the variable $\mathrm{C}$ with a constant whose value would be one Pascal. This is analogous to forcing a fit through the origin for a linear function. Using either form produced similar results so all of the data was modeled using equation (7). The curve fitted equation is only applicable in the range in which the data was obtained. Using the nonlinear equation (7) as the model, the data in Table 3-9 and Table 3-10 (along with the assumption that at zero wt \% insoluble solids the yield stress would be zero Pa) was fit to the model using TableCurve ${ }^{\circledR} 2 \mathrm{D}$ software. The resulting curves are shown in Figure 3-7 and Figure 3-8. The parameters for equation 7 and the quality of the fit are listed in Table 3-11 and Table 3-12. An examination of the B parameter for the ISPM-T6, ISPM-T7, and ISPM-T8 sludges reveals that all three are very similar, suggesting that the maximum insoluble solids parameter is about $17 \mathrm{wt} \%$. There does seem to be a difference based upon the yield stress results for the ISPM-T1 SRAT product. In general, the different methods of sludge production did not necessarily lead to different SRAT products based upon their rheological properties. 
WSRC-TR-2005-00294

Revision 0

Figure 3-7: Rheology Model Equations for the Sheared Yield Stress Results

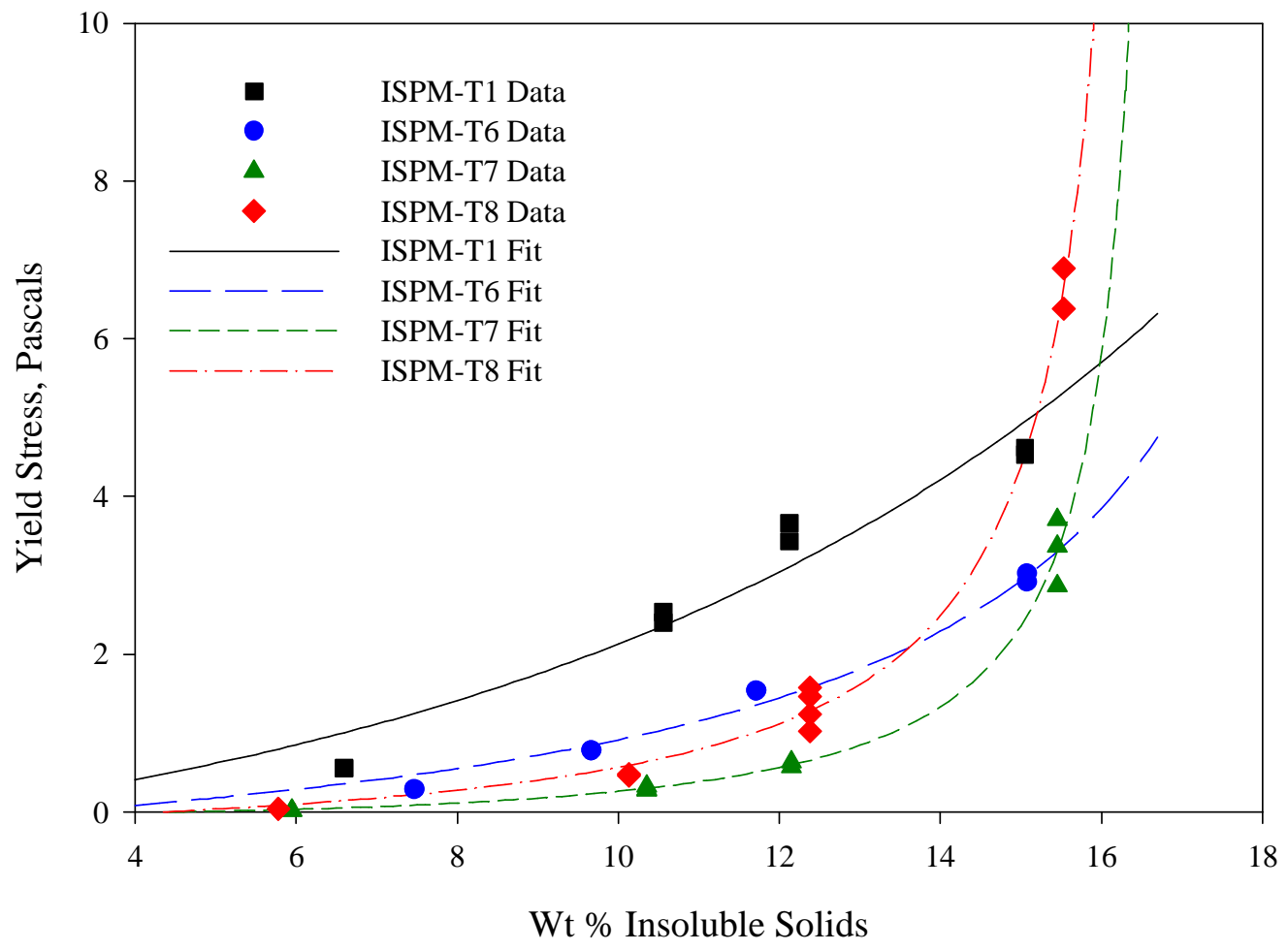

Table 3-11: Rheology Model Parameters for Sheared SRAT Products

\begin{tabular}{|c|c|c|c|c|}
\hline $\begin{array}{c}\text { SRAT } \\
\text { Product }\end{array}$ & $\begin{array}{c}\text { Factor } \\
\text { A }\end{array}$ & $\begin{array}{c}\text { Factor } \\
\text { B }\end{array}$ & $\begin{array}{c}\text { Factor } \\
\text { C, Pa }\end{array}$ & Fit $\left(\mathbf{R}^{2}\right)$ \\
\hline ISPM-T1 & 0.11 & 99.99 & 1.21 & 0.95 \\
\hline ISPM-T6 & 0.0093 & 20.78 & 1.2 & 0.98 \\
\hline ISPM-T7 & -0.066 & 16.87 & 1.01 & 0.98 \\
\hline ISPM-T8 & -0.037 & 16.74 & 1.15 & 0.99 \\
\hline
\end{tabular}


Figure 3-8: Rheology Model Equations for the Unsheared Yield Stress Results

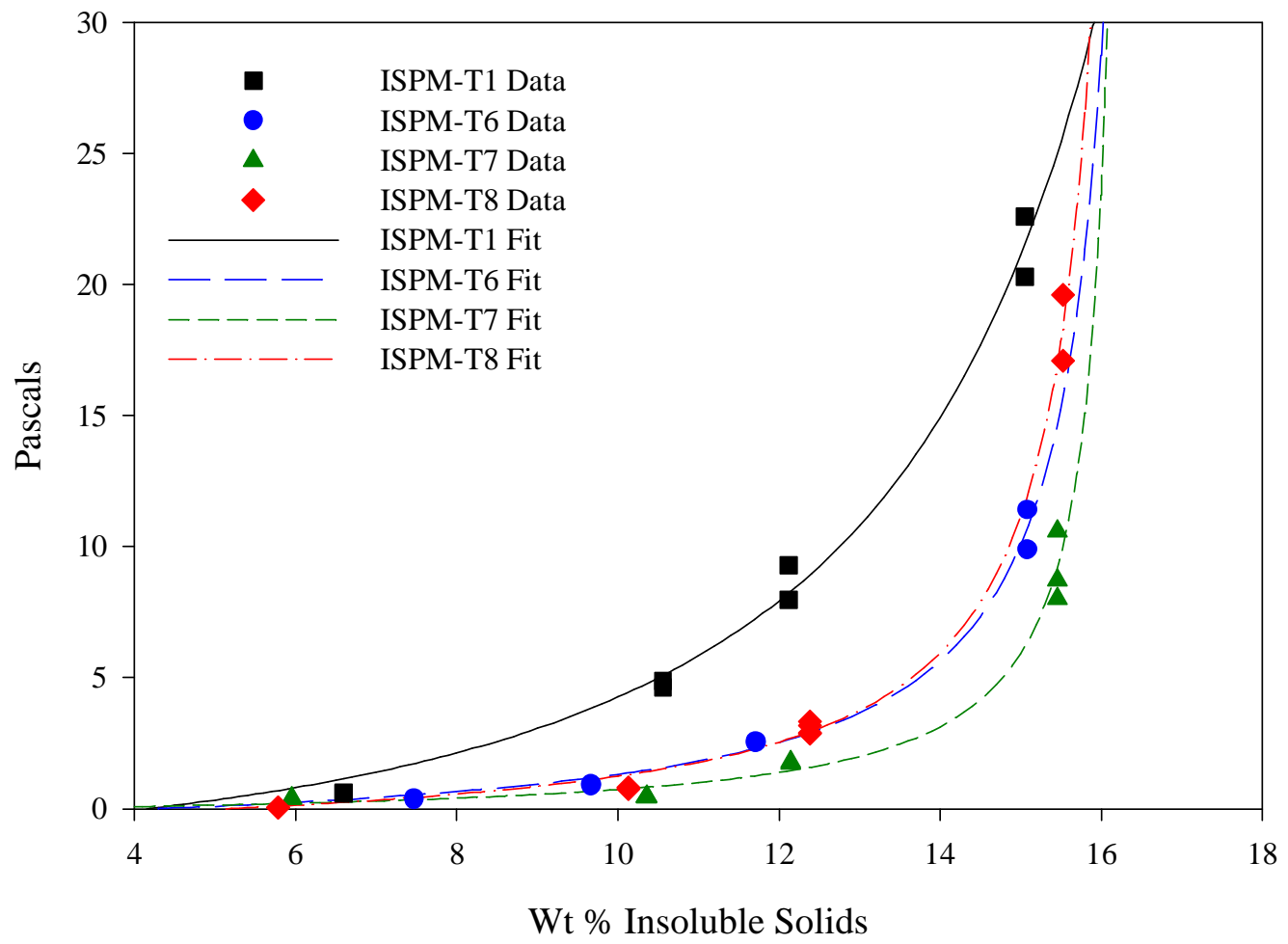

Table 3-12: Rheology Model Parameters for Unsheared SRAT Products

\begin{tabular}{|c|c|c|c|c|}
\hline $\begin{array}{c}\text { SRAT } \\
\text { Product }\end{array}$ & $\begin{array}{c}\text { Factor } \\
\text { A }\end{array}$ & $\begin{array}{c}\text { Factor } \\
\text { B }\end{array}$ & $\begin{array}{c}\text { Factor } \\
\mathbf{C}, \text { Pa }\end{array}$ & Fit $\left(\mathbf{R}^{\mathbf{2}}\right)$ \\
\hline ISPM-T1 & 0.112 & 19.54 & 2.02 & 0.99 \\
\hline ISPM-T6 & 0.0073 & 16.62 & 1.39 & 0.99 \\
\hline ISPM-T7 & -0.035 & 16.38 & 1.07 & 0.97 \\
\hline ISPM-T8 & 0.0077 & 16.46 & 1.51 & 0.99 \\
\hline
\end{tabular}

Before testing began, it was hypothesized that the SRAT process would eliminate the physical property disparities on the differently prepared test sludges due to the chemistry of the SRAT process. If this had occurred, all of the products would have similar rheological properties. The rheology of the sheared sludge feeds to the SRAT runs as a function of insoluble solids is shown in Figure 3-9. ${ }^{2}$ Before the SRAT run, the Test 6 and the Test 1 sludge were thicker than the Test 7 and 8 sludges, which were similar. A comparison of Figure 3-9 and Figure 3-7 reveals that while all of the sludges became more fluid for a given wt \% insoluble solids, not all of the feeds were modified to produce a similar product based on rheology. The ISPM-T6 sludge was altered the most while the ISPM-1 sludge remained thicker. Therefore, the conclusion from this study is that the SRAT does not eliminate physical property differences between sludges prepared by different methods. 
WSRC-TR-2005-00294

Revision 0

Figure 3-9: Yield Stress Curves for the Starting SRAT Feed

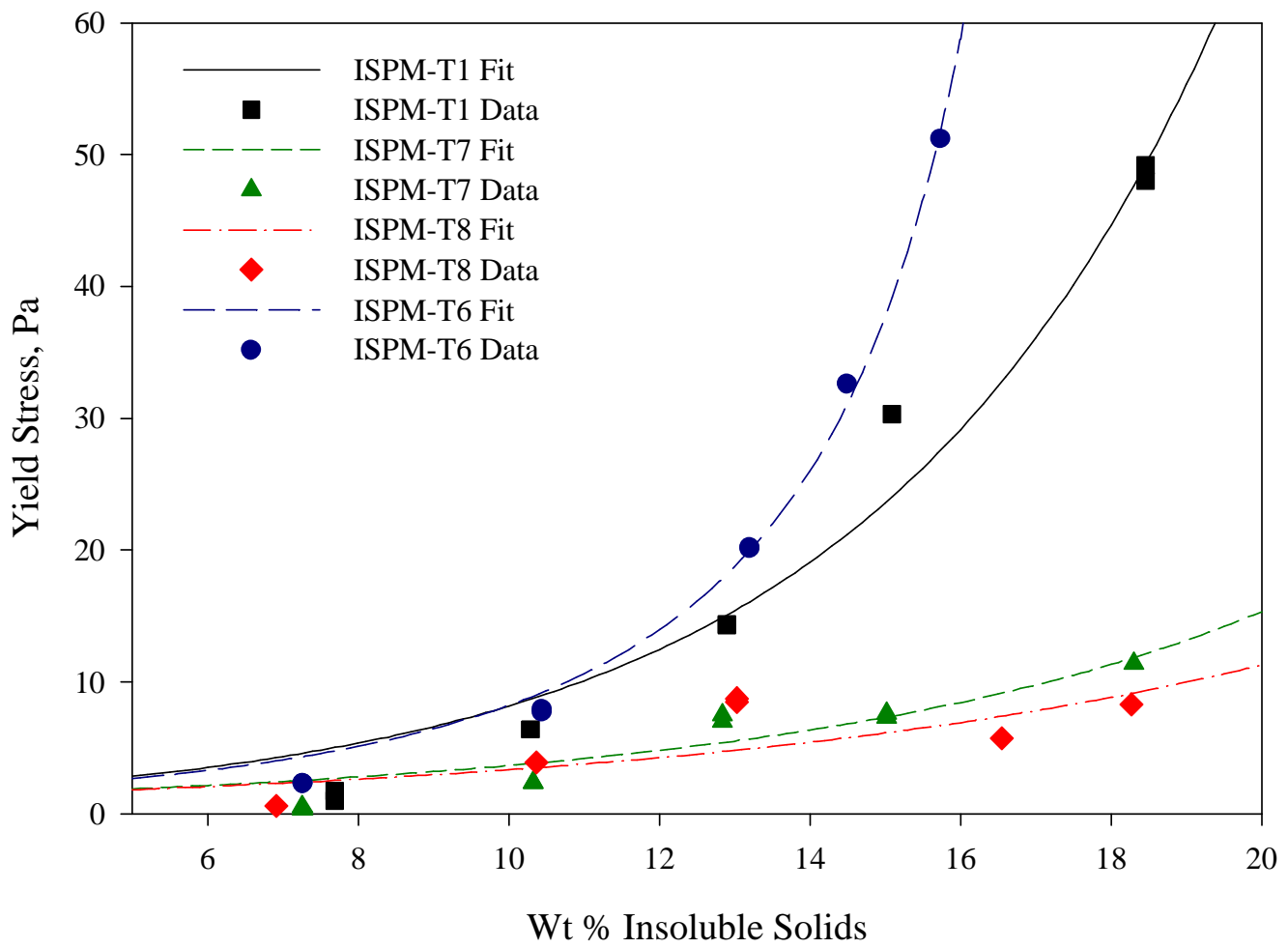

Note that similar model equations can be produced using equation 7 by applying the total solids values instead of insoluble solids. The plastic viscosity (consistency) results did not fit as well to equation 7 , since the data was more nearly linear with respect to insoluble or total solids loading. The results of the consistency fits will not be given in this report.

\subsection{SRAT Product Particle Size}

SRAT product samples were analyzed for particle size after dilution with water. Table 3-13 and Figure 3-10 summarize the data from this analysis. The particle size distribution of ISPM-T6, ISPM-T7 and ISPM-T8 SRAT Products were very similar with a major peak at approximately $25 \bullet \mathrm{m}$ and a smaller peak at $8 \bullet \mathrm{m}$. The ISPM-T1 SRAT Product has a single peak at approximately $10 \bullet \mathrm{m}$. ISPM-T1 also appeared to be the most viscous. ISPM-T1 SRAT product had the smallest average particle size by volume while ISPM-T6 SRAT product had the largest particle size by volume. ISPM-T1 SRAT product had the smallest average particle size by number while ISPM-T8 SRAT product had the largest particle size by number.

SRAT processing had minimal impact on the ISPM-T8 Sludge particle size and particle distribution as can be seen in Figure 3-11. The ISPM-T8 Sludge had two peaks both before and after processing. The heat treatment and coprecipitation produced insoluble solids that were stable throughout the SRAT process. In contrast, ISPM-T1 sludge had a significant change in particle size as the result of the SRAT processing with the large particles becoming significantly smaller and the smallest particles becoming larger. The SRAT product had a single broad peak at approximately $10 \bullet \mathrm{m}$ while the starting sludge had two peaks. Also, the distribution of the two peaks was very different from the two peaks seen in ISPM-T6, ISPM-T7 and ISPMT8. 
This data should be compared with actual sludge particle size distribution when available. In addition, testing of the particle size should be repeated using supernate, not water to dilute the sample as the large change in ionic strength due to the dilution by water may have dissolved some samples or broken up weak agglomerates into smaller particles.

Table 3-13: Particle Size of Sludge and SRAT Products

\begin{tabular}{|c|c|c|c|c|}
\hline Analysis & ISPM-T1 & ISPM-T6 & ISPM-T7 & ISPM-T8 \\
\hline Sludge Mean Particle Size, Volume Basis, $\bullet \mathbf{m}$ & 33.8 & 22.4 & 19.7 & 20.1 \\
\hline SRAT Product Mean Particle Size, Volume Basis, $\bullet \mathbf{m}$ & 15.78 & 29.12 & 19.18 & 18.81 \\
\hline Sludge Mean Particle Size, Number Basis, $\bullet$ m & 0.75 & 1.7 & 2 & 2.1 \\
\hline SRAT Product Mean Particle Size, Number Basis, $\bullet \mathbf{m}$ & 1.191 & 1.294 & 1.52 & 3.052 \\
\hline Sludge Mean Particle Size, Area Basis, $\bullet$ m & 10.4 & 9 & 9.1 & 8.8 \\
\hline SRAT Product Mean Particle Size, Area Basis, $\bullet$ m & 6.484 & 10.75 & 9.382 & 10.47 \\
\hline
\end{tabular}

Note: Measured on a single sample diluted with water.

Figure 3-10: Particle Size, volume basis, for All Runs

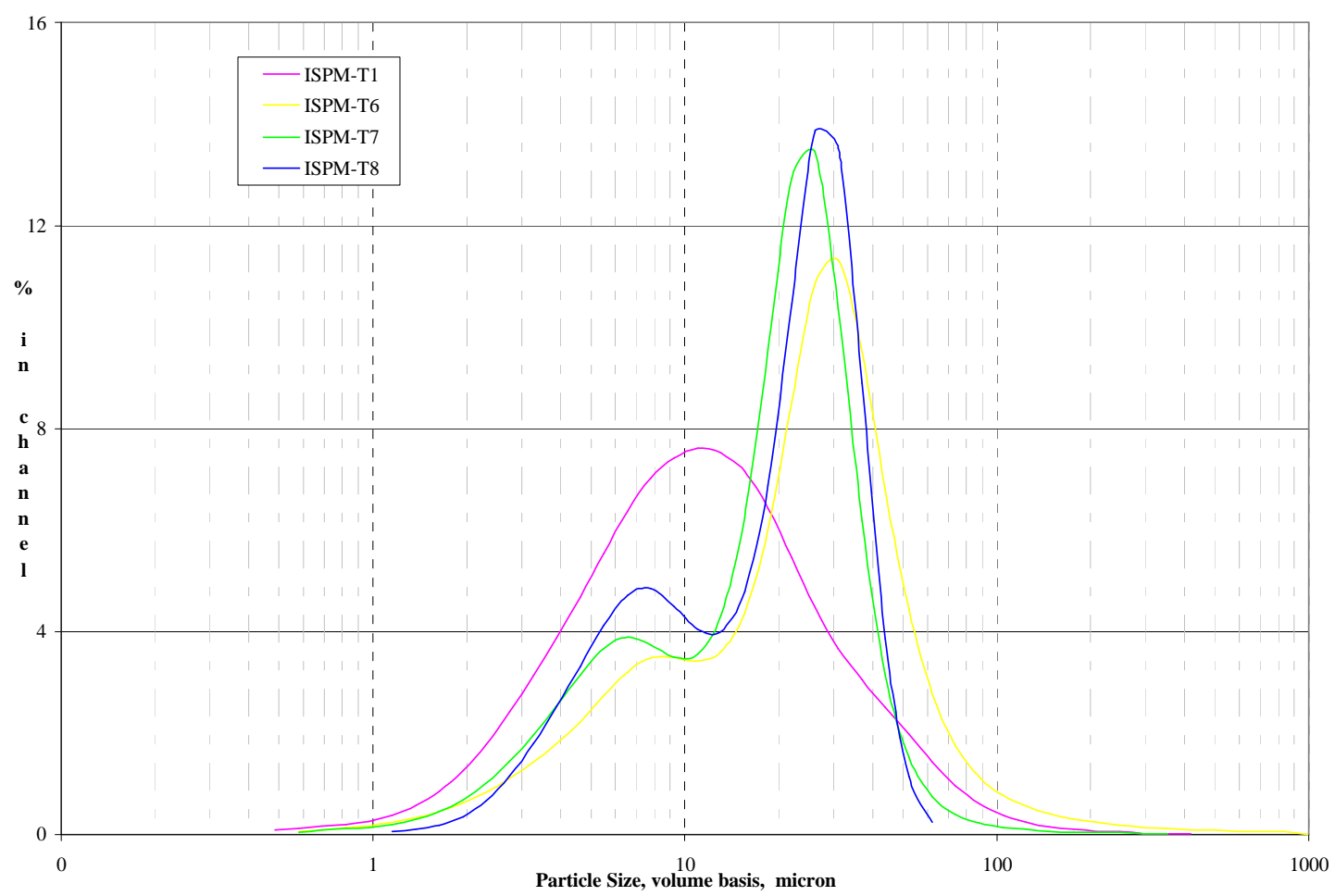


WSRC-TR-2005-00294

Revision 0

Figure 3-11: Particle Size, volume basis, for ISPM-T1 and ISPM-T8

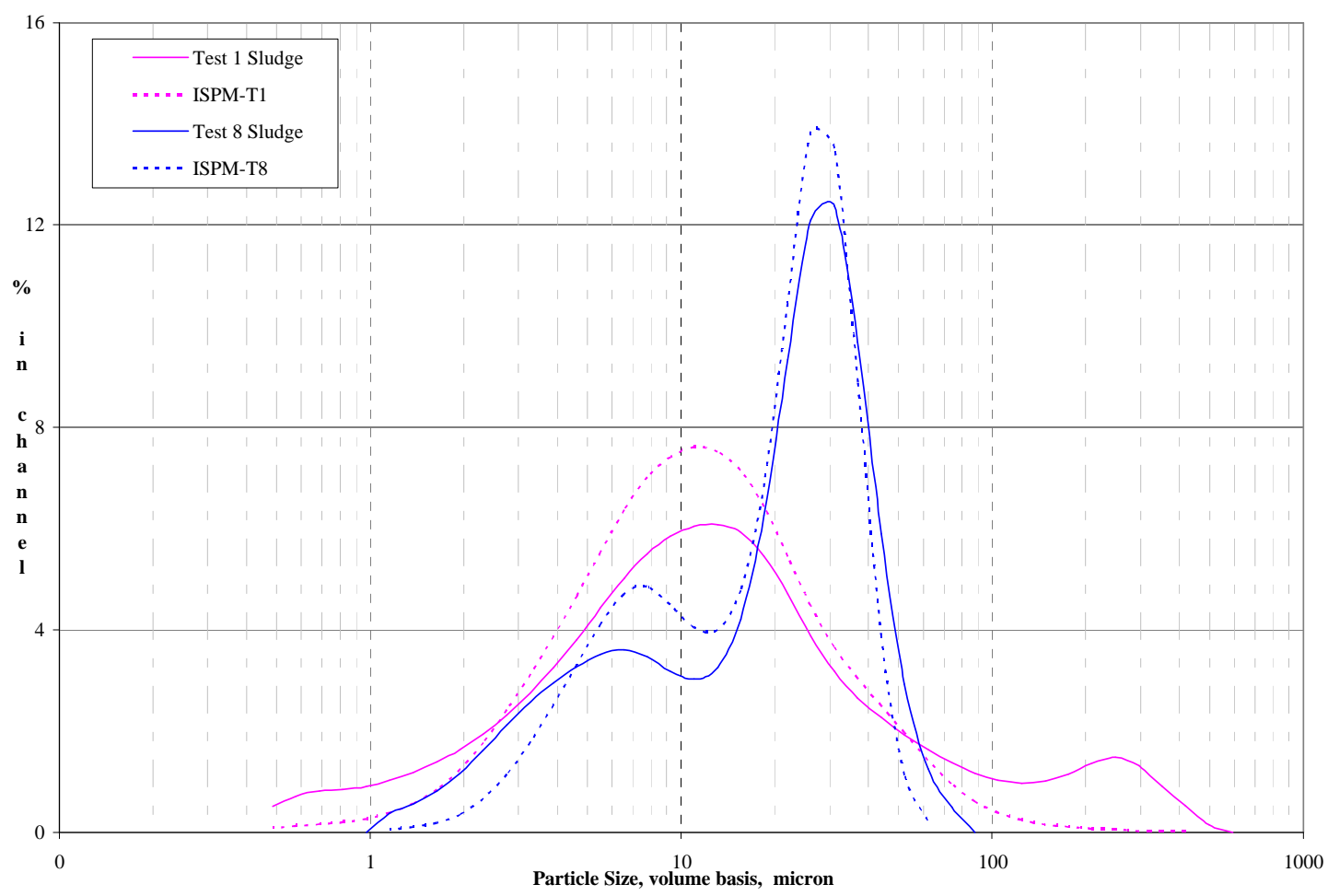


WSRC-TR-2005-00294

Revision 0

This page intentionally left blank. 


\subsection{CONCLUSIONS}

Four SRAT cycles were completed to determine the impact of the sludge preparation method on SRAT processing, SRAT product chemistry, rheology and particle size. The four sludge batches were processed through SRAT cycles, and the resulting SRAT product was analyzed to determine the impact of SRAT processing on chemical and physical properties. The following conclusions result from this study:

- The chemistry of the SRAT process does not mitigate the differences in rheology and particle size distribution between differently prepared sludges of the same nominal composition. Before testing began, it was hypothesized that the impact of the SRAT process on the differently prepared test sludges would be the elimination of physical property differences due to the chemistry of the SRAT process. If this had occurred, all of the products would have similar rheological properties. Instead, the conclusion from this study is that the SRAT does not eliminate physical property differences between sludges prepared by different methods.

- The chemical composition of the four starting sludge simulants and the four resulting SRAT products were very similar as desired and/or expected.

- The rheological and particle size distribution properties of the SRAT products from Tests 6, 7, and 8 starting sludges were very similar, but clearly different from those of the baseline simulant used in Test 1 .

- The $\mathrm{pH}$ profile and resulting final $\mathrm{pH}$ were very similar. As expected, the minimum SRAT $\mathrm{pH}$ occurred at end of acid addition. The measured minimum $\mathrm{pH}$ ranged from 4.04-4.14. All runs had a SRAT product $\mathrm{pH}$ in the range of $\mathrm{pH} 4.62-4.94$.

- The formate destruction was similar, the destruction efficiency varied from $11 \%$ to $22 \%$.

- The more concentrated samples had the highest yield stress values. The average yield stress for the sheared SRAT product at $15 \mathrm{wt} \%$ insoluble solids ranged from 2.96-6.64 Pa or 29.6-66.4 dynes $/ \mathrm{cm}^{2}$. The highest yield stress was for the $15 \mathrm{wt} \%$ SRAT product prepared from Test 8 sludge.

- The plastic viscosity for the sheared SRAT product at $15 \mathrm{wt} \%$ insoluble solids ranged from 19.4$28.8 \mathrm{cp}$. The highest plastic viscosity was for the $15 \mathrm{wt} \%$ SRAT product prepared from Test 8 sludge.

- The yield stress of each of the four SRAT products was within the operating window for DWPF rheology. The sharp increase in yield stress of the $15 \mathrm{wt} \%$ insoluble solids ISPM-T8 SRAT product suggests that simulant processing above $15 \mathrm{wt} \%$ insoluble solids should be avoided.

- The particle size distributions of the sludges and SRAT products from the three new sludge preparation methods were very similar before and after the SRAT cycles. The particle size distribution of the baseline sludge changed considerably during processing with fewer small and large particles in the SRAT product.

- ISPM-T1 SRAT product had the smallest average particle size by volume and number. ISPMT6, ISPM-T7, and ISPM-T8 are nearly identical in volume mean particle size.

- $\quad$ SRAT processing had minimal impact on the ISPM-T8 Sludge particle size and particle distribution. The ISPM-T8 Sludge had two peaks both before and after processing. The heat treatment and coprecipitation produced insoluble solids that were stable throughout the SRAT process. In contrast, Test 1 sludge had a significant change in particle size as the result of the SRAT processing with the large particles becoming significantly smaller and the smallest particles becoming larger. The SRAT product had a single broad peak at approximately $10 \bullet \mathrm{m}$ while the starting sludge had two peaks. Also, the distribution of the two peaks was very different from the two peaks seen in ISPM-T6, ISPM-T7, and ISPM-T8.

- The chemistry of the SRAT process does not mitigate the differences between differently prepared sludges of the same nominal composition. 
WSRC-TR-2005-00294

Revision 0

This page intentionally left blank. 


\subsection{RECOMMENDATIONS}

- The particle size data should be compared with actual sludge particle size distribution when available.

- Testing of the particle size should be repeated using supernate, not water to dilute the sample as the large change in ionic strength due to the dilution by water may have dissolved some samples or broken up weak agglomerates into smaller particles.

- Research on the processes that control the physical properties of simulants should continue and include those that are impacted by the scale of the production method and by the chemical composition of the sludge.

- When new simulants or new methods of producing simulants are developed, these simulants should be tested for their impact on the physical properties of the SRAT product. 
WSRC-TR-2005-00294

Revision 0

This page intentionally left blank. 


\subsection{REFERENCES}

1 Fowler, J. R., Carter, J. T., Landon, L.F., Marek, J. C., and C. L. Pearson. Development of Feed Simulant Specifications for Integrated Cold Runs in the Defense Waste Processing Facility (U). WSRC-RP-89-238, Savannah River Site, Aiken SC 29808 (July 1989).

2 Eibling, R. E., Impact of Simulant Production Methods on the Physical Properties of DWPF Sludge Batch 3 Simulant, WSRC-TR-2004-00578, Savannah River Site, Aiken, SC 29808 (2005).

3 Pareizs, J. M., Fellinger, T. L. and Click, D. R, Characterization of the March 2004 Tank 40 (Sludge Batch 3) Dip Samples, WSRC-TR-2004-00208, Savannah River Site, Aiken, SC 29808 (2004).

4 Stone, M.E., SB3 Test 1 Run Plan (Impact of Simulant Production Methods on SRAT Product) with No Hg. SRT-ITS-2005-00080, Savannah River Site, Aiken, SC 29808 (2005).

5 Stone, M.E., SB3 Test 6 Run Plan (Impact of Simulant Production Methods on SRAT Product) with No Hg. SRT-ITS-2005-00089, Savannah River Site, Aiken, SC 29808 (2005).

6 Stone, M.E., SB3 Test 7 Run Plan (Impact of Simulant Production Methods on SRAT Product) with No Hg. SRT-ITS-2005-00090, Savannah River Site, Aiken, SC 29808 (2005).

7 Stone, M.E., SB3 Test 8 Run Plan (Impact of Simulant Production Methods on SRAT Product) with No Hg. SRT-ITS-2005-00087, Savannah River Site, Aiken, SC 29808 (2005).

8 Jantzen, C.M., J.R. Zamecnik, D.C. Koopman, C.C. Herman, and J.B. Pickett, Electron Equivalents Model for Controlling Reduction-Oxidation (Redox) Equilibrium during High Level Waste (HLW) Vitrification. WSRC-TR-2003-00126, Savannah River Site, Aiken, SC 29808 (2003).

9 Baich, M.A., Analytical Study Plan for "Sludge Batch 4 with ARP and MCU Flowsheet Studies using Simulants. SRNL-GPD-2005-00001, Savannah River Site, Aiken, SC 29808 (2005).

10 Koopman, D. C., Rheological Characterization of Unusual DWPF Slurry samples (U). WSRC-TR-200400519. Savannah River Site, Aiken, SC 29808 (2005).

11 The Transportation of Solids In Steel Pipelines. Colorado School of Mines Research Foundation, Inc. Golden, CO (1963).

12 Shook, C. A and M. C. Roco. Slurry Flow Principles and Practice. p.62, Butterworth-Heinemann, Boston, MA (1991).

13 Krieger, I. M., "Rheology of Monodisperse Lattices". Advances Colloid Interface Science 3, (1972).

14 Marek, J. C., Preliminary Melter Feed Rheology Study (U). WSRC-RP-92-1240, Savannah River Site, Aiken SC 29808 (October 21, 1992).

15 Marek, J. C., Rheology of SME Product from Alternative Sludge-Only Flowsheet with Batch One Sludge Simulant (U). WSRC-TR-96-0179, Savannah River Site, Aiken SC 29808 (June 26, 1996). 
WSRC-TR-2005-00294

Revision 0

This page intentionally left blank. 


\subsection{ACKNOWLEDGMENTS}

The authors would like to acknowledge the following personnel and groups for their assistance in performing the studies and analyzing the required samples:

- T.O. Burckhalter, J.W. Duvall, S.O. King, I.A. Reamer, V.J. Williams, and R.J. Workman, for fabricating the sludge simulants, performing the SRAT runs and assisting with sample analysis.

- D. R. Best, P.A. Toole, J. Jansen, and J.G. Wheeler for providing assistance with the analyses.

- J.E. Young, L.C. Johnson, and ADS for providing analytical support.

- M. F. Williams for coordinating the testing and technicians to ensure the runs were completed as planned. 
WSRC-TR-2005-00294

Revision 0

This page intentionally left blank. 
WSRC-TR-2005-00294

Revision 0

\section{APPENDIX A. SRAT RUN PARAMETERS}


Table A - 1: Sludge Batch 3 Compositional Basis ${ }^{3}$

\begin{tabular}{|c|c|c|c|c|}
\hline Basis & Measured Solids & Measured Slurry & Slurry & Concentration \\
\hline Analyte & microgram/gram & microgram/gram & $\begin{array}{c}\text { g/L } \\
\text { slurry }\end{array}$ & moles/Liter \\
\hline $\mathrm{Ag}$ & 300 & & 0.0714 & $6.62 \mathrm{E}-04$ \\
\hline $\mathrm{Al}$ & 60400 & & 14.3752 & 5.33E-01 \\
\hline B & 100 & & 0.0238 & $2.20 \mathrm{E}-03$ \\
\hline $\mathrm{Ba}$ & 500 & & 0.1190 & $8.67 E-04$ \\
\hline $\mathrm{C}_{2} \mathrm{O}_{4}{ }^{-2}$ & & 1033 & 1.2293 & $1.40 \mathrm{E}-02$ \\
\hline $\mathrm{Ca}$ & 16600 & & 3.9508 & $9.86 \mathrm{E}-02$ \\
\hline $\mathrm{Cd}$ & 1900 & & 0.4522 & $4.02 \mathrm{E}-03$ \\
\hline $\mathrm{Ce}$ & 1100 & & 0.2618 & $1.87 \mathrm{E}-03$ \\
\hline $\mathrm{Cl}$ & & 200 & 0.2380 & $6.71 \mathrm{E}-03$ \\
\hline Cr(TOTAL) & 2500 & & 0.5950 & $1.14 \mathrm{E}-02$ \\
\hline $\mathrm{Cu}$ & 300 & & 0.0714 & $1.12 \mathrm{E}-03$ \\
\hline $\mathrm{F}$ & 235 & 235 & 0.2797 & $1.47 \mathrm{E}-02$ \\
\hline $\mathrm{Fe}$ & 194400 & & 46.2672 & $8.28 \mathrm{E}-01$ \\
\hline $\mathrm{Gd}$ & 500 & & 0.1190 & $7.57 \mathrm{E}-04$ \\
\hline $\mathrm{K}$ & 3300 & & 0.7854 & $2.01 E-02$ \\
\hline $\mathrm{La}$ & 400 & & 0.0952 & $6.85 \mathrm{E}-04$ \\
\hline $\mathrm{Li}$ & 400 & & 0.0952 & $1.37 \mathrm{E}-02$ \\
\hline $\mathrm{Mg}$ & 16700 & & 3.9746 & $1.64 \mathrm{E}-01$ \\
\hline $\mathrm{Mn}$ & 39500 & & 9.4010 & $1.71 \mathrm{E}-01$ \\
\hline Mo & 500 & & 0.1190 & $1.24 \mathrm{E}-03$ \\
\hline $\mathrm{Na}$ & 120600 & & 28.7028 & $1.25 \mathrm{E}+00$ \\
\hline $\mathrm{Ni}$ & 10900 & & 2.5942 & $4.42 \mathrm{E}-02$ \\
\hline $\mathrm{NO}_{2}^{-}$ & & 15462 & 18.3998 & $4.00 \mathrm{E}-01$ \\
\hline $\mathrm{NO}_{3}^{-}$ & & 10536 & 12.5378 & $2.02 \mathrm{E}-01$ \\
\hline $\mathrm{OH}^{-}$ & & & 7.3132 & 4.30E-01 \\
\hline $\begin{array}{l}\text { P (by ICP- } \\
\text { ES) }\end{array}$ & 4300 & & 1.0234 & $3.30 \mathrm{E}-02$ \\
\hline $\mathrm{Pb}$ & 600 & & 0.1428 & $6.89 \mathrm{E}-04$ \\
\hline $\mathrm{PO}_{4}^{-3}$ (by IC) & & 940 & 1.1186 & $1.18 \mathrm{E}-02$ \\
\hline $\mathrm{S}$ & 2900 & & 0.6902 & $2.15 \mathrm{E}-02$ \\
\hline $\mathrm{Sb}$ & 600 & & 0.1428 & $1.17 \mathrm{E}-03$ \\
\hline $\mathrm{Si}$ & 4000 & & 0.9520 & 3.39E-02 \\
\hline $\mathrm{Sn}$ & 500 & & 0.1190 & $1.00 \mathrm{E}-03$ \\
\hline $\mathrm{SO}_{4}^{-2}$ & & 1689 & 2.0099 & $2.09 \mathrm{E}-02$ \\
\hline $\mathrm{Sr}$ & 4200 & & 0.9996 & $1.14 \mathrm{E}-02$ \\
\hline $\mathrm{Ti}$ & 200 & & 0.0476 & $9.94 \mathrm{E}-04$ \\
\hline $\mathrm{U}$ & 69900 & & 16.6362 & 6.99E-02 \\
\hline $\mathrm{V}$ & 100 & & 0.0238 & $4.67 \mathrm{E}-04$ \\
\hline $\mathrm{Zn}$ & 300 & & 0.0714 & $1.09 \mathrm{E}-03$ \\
\hline $\mathrm{Zr}$ & 100 & & 0.0238 & 2.61E-04 \\
\hline
\end{tabular}


WSRC-TR-2005-00294

Revision 0

Table A - 2: SRAT Run Parameters

\begin{tabular}{|c|c|c|c|c|}
\hline Parameter & ISPM-T1 & ISPM-T6 & ISPM-T7 & ISPM-T8 \\
\hline Initial Sludge Mass (g) & 785.4 & 785.4 & 785.4 & 785.4 \\
\hline Hg Target (wt\% in total solids) & 0 & 0 & 0 & 0 \\
\hline HgO Added (g) & 0 & 0 & 0 & 0 \\
\hline $\mathrm{AgNO}_{3}$ Added (g) & 0 & 0 & 0 & 0 \\
\hline $\mathrm{Pd}\left(\mathrm{NO}_{3}\right)_{2} * \mathrm{H}_{2} \mathrm{O}$ Added $(\mathrm{g})-15.27 \%$ Solution & 0.0109 & 0.0113 & 0.0117 & 0.0111 \\
\hline $\mathrm{Rh}\left(\mathrm{NO}_{3}\right)_{3} * 2 \mathrm{H}_{2} \mathrm{O}$ Added $(\mathrm{g})-4.93 \%$ Solution & 0.1863 & 0.1865 & 0.1877 & 0.1865 \\
\hline $\mathrm{RuCl}_{3}$ Added (d) & 0.1043 & 0.1042 & 0.1059 & 0.1045 \\
\hline Rinse Water for Trim Chemicals (g) & 40 & 40 & 44.99 & 40 \\
\hline DWPF SRAT Scale Factor (6,000 gallon basis) & $1: 32,400$ & $1: 32,400$ & $1: 32,400$ & $1: 32,400$ \\
\hline Acid Stoichiometry & $155 \%$ & $155 \%$ & $155 \%$ & $155 \%$ \\
\hline Nitric Acid Amount Added (ml) & 22.894 & 22.526 & 22.618 & 22.618 \\
\hline Nitric Acid Addition Rate (ml/min) & 0.241 & 0.240 & 0.241 & 0.228 \\
\hline Nitric Acid Moles & 0.241 & 0.237 & 0.238 & 0.238 \\
\hline Formic Acid Amount Added (ml) & 60.901 & 60.360 & 60.461 & 61.297 \\
\hline Formic Acid Addition Rate (ml/min) & 0.249 & 0.248 & 0.240 & 0.248 \\
\hline Formic Acid Moles & 1.442 & 1.420 & 1.424 & 1.456 \\
\hline Total SRAT Dewater Amount (g) & 175.500 & 188.580 & 182.300 & 183.690 \\
\hline Dewater Amount after Reflux (g) & 55.35 & 73.80 & 61.50 & 54.90 \\
\hline Concentration/Dewater Time after Boiling (hrs) & 0.75 & 1.00 & 0.83 & 0.75 \\
\hline SRAT Target Boil-up Rate (g/min) & 1.23 & 1.23 & 1.23 & 1.22 \\
\hline SRAT Air Purge on System (sccm) & 211.3 & 211.3 & 211.3 & 211.3 \\
\hline SRAT Helium Purge on System (sccm) & 0 & 0 & 0 & 0 \\
\hline Initial Sludge pH with Trim Chemicals & 12.09 & 11.96 & 11.83 & 12.10 \\
\hline Minimum pH during SRAT & 4.08 & 4.04 & 4.14 & 4.09 \\
\hline pH at End of SRAT (at boiling) & 4.94 & 4.81 & 4.71 & 4.62 \\
\hline Antifoam Addition (g) & 5.81 & 5.81 & 5.81 & 5.81 \\
\hline Run Plan Document Number & $\begin{array}{l}\text { SRNL-ITS- } \\
2005-00080\end{array}$ & $\begin{array}{l}\text { SRNL-ITS- } \\
2005-00089\end{array}$ & $\begin{array}{l}\text { SRNL-ITS- } \\
2005-00090\end{array}$ & $\begin{array}{l}\text { SRNL-ITS- } \\
2005-00087 \\
\end{array}$ \\
\hline
\end{tabular}


WSRC-TR-2005-00294

Revision 0

This page intentionally left blank 
WSRC-TR-2005-00294

Revision 0

APPENDIX B. RHEOLOGY DATA

All of the rheogram measurements in Appendix B were made using the $60 \mathrm{~mm} / 2$ degree Ti cone and plate. 
Figure B - 1: Rheology of ISPM-T1-asis SRAT Product
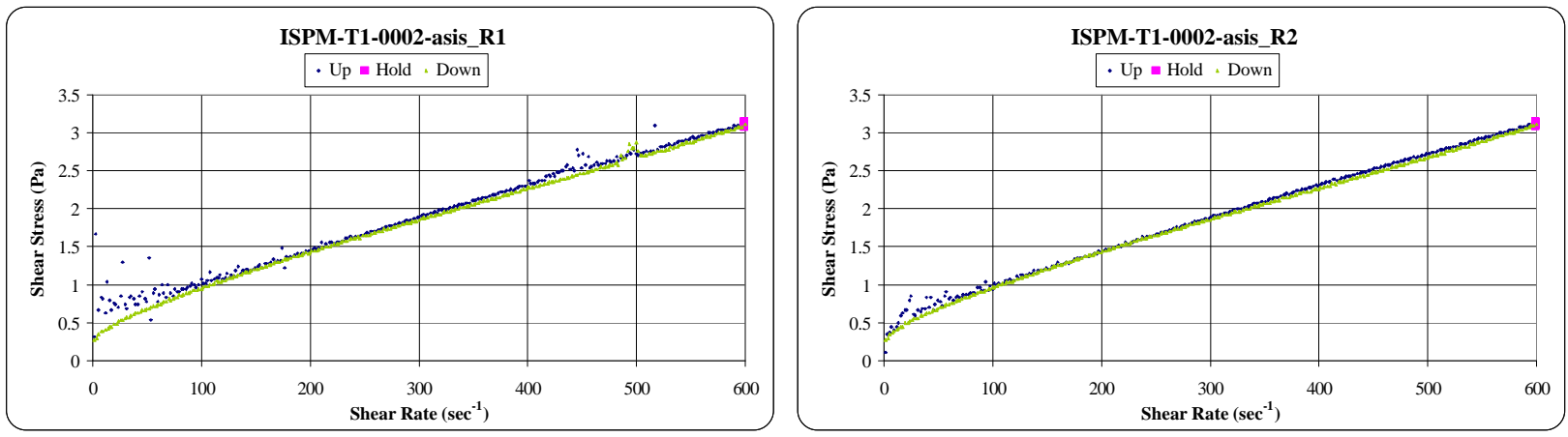

Unsheared Results (Up Flow Curve)

\begin{tabular}{|c|c|c|c|cc|}
\multicolumn{1}{c|}{} & $\begin{array}{c}\text { Plastic } \\
\text { Viscosity }(\mathrm{cP})\end{array}$ & $\begin{array}{c}\text { Yield } \\
\text { Stress } \\
(\mathrm{Pa})\end{array}$ & $\mathrm{R}^{2}$ & Date & $\begin{array}{c}\text { Range, } \\
\text { sec }^{-1}\end{array}$ \\
\hline $\begin{array}{c}\text { ISPM-T1-0002- } \\
\text { asis_R1 }\end{array}$ & 4.25 & 0.61 & 0.9932 & $4 / 27 / 2005$ & $50-600$ \\
\hline $\begin{array}{c}\text { ISPM-T1-0002- } \\
\text { asis_R2 }\end{array}$ & 4.30 & 0.58 & 0.9990 & $4 / 27 / 2005$ & $50-600$ \\
\hline Average & 4.28 & 0.60 & & & \\
\hline Stdev & 0.04 & 0.02 & & & \\
\hline \%Stdev & $0.8 \%$ & $3.6 \%$ & & &
\end{tabular}

Sheared Flow Curve Results (Down Flow Curve)

\begin{tabular}{|c|c|c|c|c|c|}
\hline \multirow[b]{2}{*}{ Sample I.D. } & \multirow[b]{2}{*}{$\begin{array}{c}\text { Plastic } \\
\text { Viscosity (cP) }\end{array}$} & \multirow[b]{2}{*}{$\begin{array}{c}\text { Yield } \\
\text { Stress } \\
(\mathrm{Pa})\end{array}$} & & & \multirow[b]{2}{*}{$\begin{array}{c}\text { Range, } \\
\mathrm{sec}^{-1}\end{array}$} \\
\hline & & & $\mathrm{R}^{2}$ & Date & \\
\hline $\begin{array}{l}\text { ISPM-T1-0002- } \\
\text { asis_R1 }\end{array}$ & 4.28 & 0.55 & 0.9980 & $4 / 27 / 2005$ & $50-600$ \\
\hline $\begin{array}{l}\text { ISPM-T1-0002- } \\
\text { asis_R2 }\end{array}$ & 4.26 & 0.56 & 0.9988 & $4 / 27 / 2005$ & $50-600$ \\
\hline Average & 4.27 & 0.56 & & & \\
\hline Stdev & 0.01 & 0.01 & & & \\
\hline$\%$ Stdev & $0.3 \%$ & $1.3 \%$ & & & \\
\hline
\end{tabular}


Figure B - 2: Rheology of ISPM-T1-10\% SRAT Product
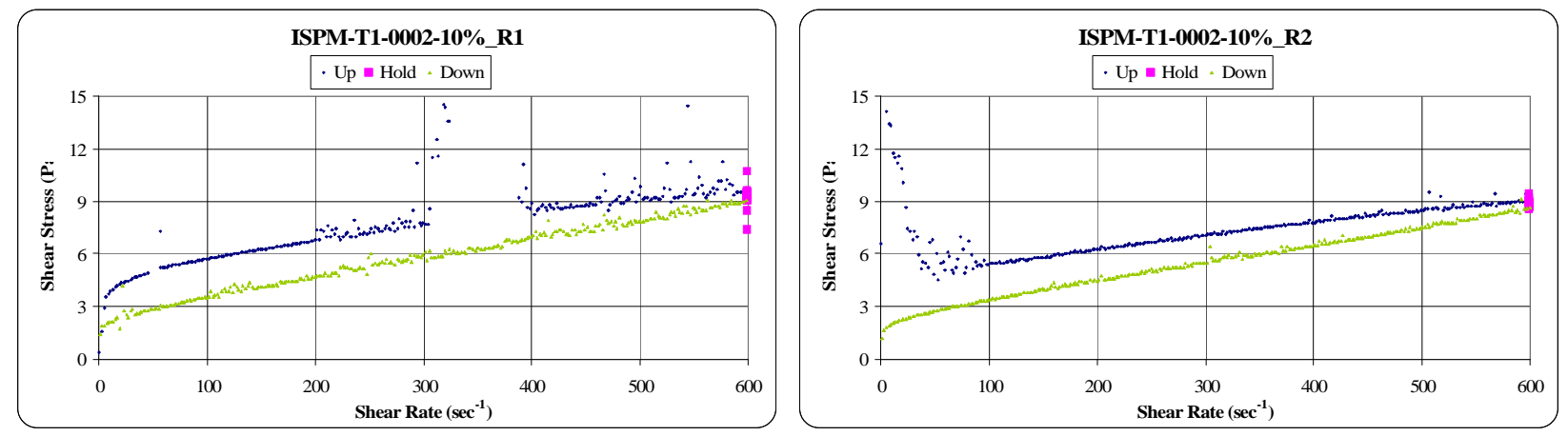

Unsheared Results (Up Flow Curve)

\begin{tabular}{|c|c|c|c|c|c|}
\hline \multirow[b]{2}{*}{ Sample I.D. } & \multirow{2}{*}{$\begin{array}{c}\text { Plastic } \\
\text { Viscosity } \\
(\mathrm{cP})\end{array}$} & \multirow{2}{*}{$\begin{array}{c}\text { Yield } \\
\text { Stress } \\
(\mathrm{Pa}) \\
\end{array}$} & & & \multirow{2}{*}{$\begin{array}{c}\text { Range, } \\
\sec ^{-1}\end{array}$} \\
\hline & & & $\mathrm{R}^{2}$ & Date & \\
\hline $\begin{array}{c}\text { ISPM-T1-0002- } \\
10 \% \_R 1\end{array}$ & 11.19 & 4.63 & 0.8057 & $4 / 28 / 2005$ & $50-300$ \\
\hline $\begin{array}{c}\text { ISPM-T1-0002- } \\
10 \% \_R 2\end{array}$ & 7.25 & 4.87 & 0.9675 & $4 / 28 / 2005$ & $50-600$ \\
\hline Average & 9.22 & 4.75 & & & \\
\hline Stdev & 2.8 & 0.17 & & & \\
\hline$\%$ Stdev & $30.2 \%$ & $3.6 \%$ & & & \\
\hline
\end{tabular}

Sheared Results (Down Flow Curve)

\begin{tabular}{|c|c|c|c|c|c|}
\hline \multirow[b]{2}{*}{ Sample I.D. } & \multirow{2}{*}{$\begin{array}{c}\text { Plastic } \\
\text { Viscosity } \\
\text { (cP) }\end{array}$} & \multirow{2}{*}{$\begin{array}{c}\text { Yield } \\
\text { Stress } \\
(\mathrm{Pa}) \\
\end{array}$} & & & \multirow{2}{*}{$\begin{array}{l}\text { Range, } \\
\sec ^{-1}\end{array}$} \\
\hline & & & $\mathrm{R}^{2}$ & Date & \\
\hline $\begin{array}{c}\text { ISPM-T1-0002- } \\
10 \% \_R 1\end{array}$ & 10.91 & 2.53 & 0.9912 & $4 / 28 / 2005$ & $50-600$ \\
\hline $\begin{array}{c}\text { ISPM-T1-0002- } \\
10 \% \_R 2\end{array}$ & 10.34 & 2.40 & 0.9962 & $4 / 28 / 2005$ & $50-600$ \\
\hline Average & 10.63 & 2.47 & & & \\
\hline Stdev & 0.4 & 0.09 & & & \\
\hline$\%$ Stdev & $3.8 \%$ & $3.7 \%$ & & & \\
\hline
\end{tabular}


Figure B - 3: Rheology of ISPM-T1-12\% SRAT Product
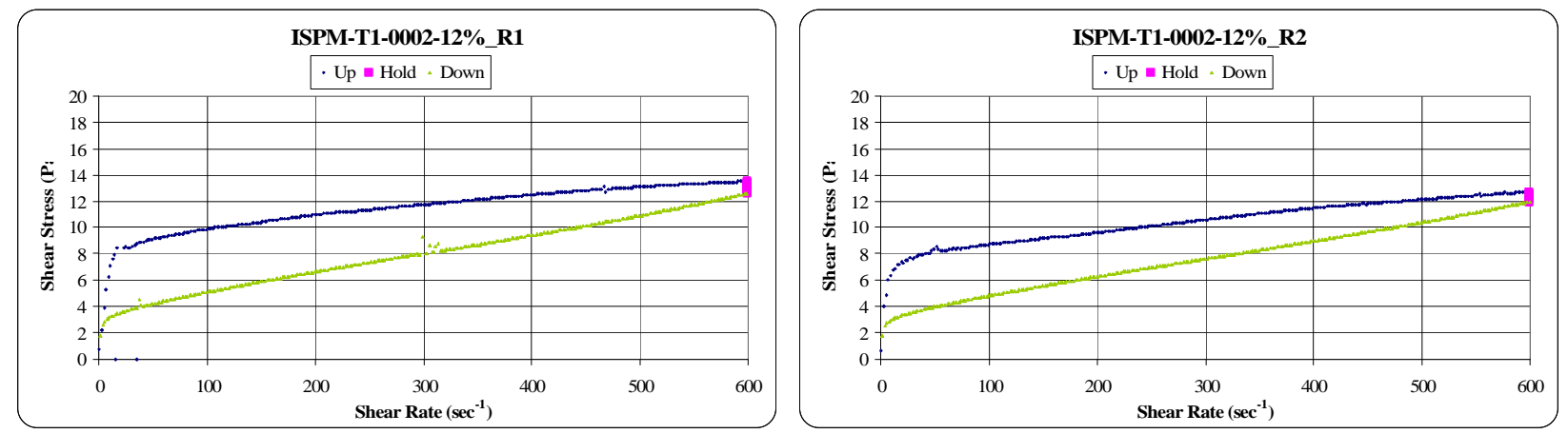

Unsheared Results (Up Flow Curve)

\begin{tabular}{|c|c|c|c|c|c|}
\hline & & & \multirow[b]{3}{*}{$\mathrm{R}^{2}$} & \multirow[b]{3}{*}{ Date } & \multirow{3}{*}{$\begin{array}{c}\text { Range, } \\
\sec ^{-1}\end{array}$} \\
\hline \multirow[b]{2}{*}{ Sample I.D. } & \multirow{2}{*}{$\begin{array}{c}\text { Plastic } \\
\text { Viscosity } \\
\text { (cP) }\end{array}$} & \multirow{2}{*}{$\begin{array}{c}\text { Yield } \\
\text { Stress } \\
(\mathrm{Pa})\end{array}$} & & & \\
\hline & & & & & \\
\hline $\begin{array}{c}\text { ISPM-T1-0002- } \\
12 \% \text { R } 1\end{array}$ & 7.67 & 9.30 & 0.9799 & $5 / 3 / 2005$ & $50-600$ \\
\hline $\begin{array}{c}\text { ISPM-T1-0002- } \\
12 \% \text { R2 }\end{array}$ & 8.39 & 7.98 & 0.9916 & $5 / 3 / 2005$ & $50-600$ \\
\hline Average & 8.03 & 8.64 & & & \\
\hline Stdev & 0.51 & 0.93 & & & \\
\hline$\%$ Stdev & $6.3 \%$ & $10.8 \%$ & & & \\
\hline
\end{tabular}

Sheared Results (Down Flow Curve)

\begin{tabular}{|c|c|c|c|c|c|}
\multicolumn{1}{c|}{$\begin{array}{c}\text { Plastic } \\
\text { Viscosity } \\
(\mathrm{cP})\end{array}$} & $\begin{array}{c}\text { Yield } \\
\text { Stress } \\
(\mathrm{Pa})\end{array}$ & $\mathrm{R}^{2}$ & Date & $\begin{array}{c}\text { Range, } \\
\text { sec }^{-1}\end{array}$ \\
\hline $\begin{array}{c}\text { ISPM-T1-0002- } \\
\text { 12\%_R1 }\end{array}$ & 14.62 & 3.66 & 0.9976 & $5 / 3 / 2005$ & $50-600$ \\
\hline $\begin{array}{c}\text { ISPM-T1-0002- } \\
\text { 12\%_R2 }\end{array}$ & 14.01 & 3.43 & 0.9996 & $5 / 3 / 2005$ & $50-600$ \\
\hline Average & 14.32 & 3.55 & & & \\
\hline Stdev & 0.43 & 0.16 & & & \\
\hline \%Stdev & $3.0 \%$ & $4.6 \%$ & \multicolumn{1}{|c}{} \\
\hline
\end{tabular}


Figure B - 4: Rheology of ISPM-T1-15\% SRAT Product
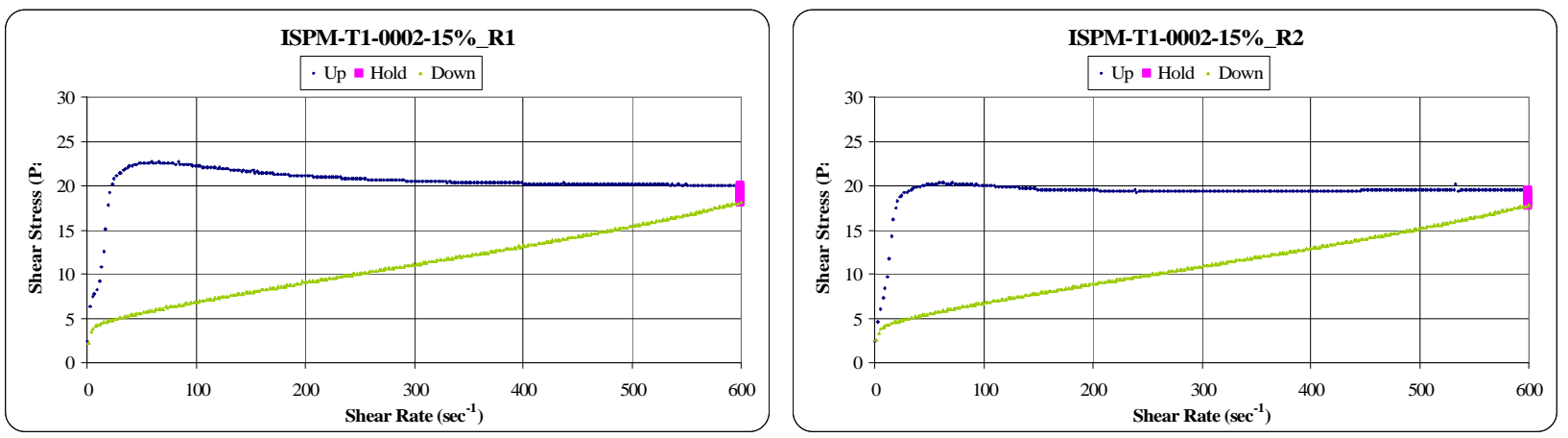

Unsheared Results (Up Flow Curve)

\begin{tabular}{|c|c|c|c|c|c|}
\hline & & \multirow[b]{2}{*}{$\begin{array}{c}\text { Yield } \\
\text { Stress } \\
(\mathrm{Pa})\end{array}$} & & & \multirow[b]{2}{*}{$\begin{array}{l}\text { Range, } \\
\sec ^{-1}\end{array}$} \\
\hline Sample I.D. & $\begin{array}{c}\text { Plastic } \\
\text { Viscosity } \\
(\mathrm{cP})\end{array}$ & & $\mathrm{R}^{2}$ & Date & \\
\hline $\begin{array}{c}\text { ISPM-T1-0002- } \\
15 \% \_R 1\end{array}$ & NA & $22.64 *$ & NA & $5 / 4 / 2005$ & NA \\
\hline $\begin{array}{c}\text { ISPM-T1-0002- } \\
15 \% \_R 2\end{array}$ & NA & $20.29 *$ & NA & $5 / 4 / 2005$ & NA \\
\hline Average & NA & 21.47 & & & \\
\hline Stdev & NA & 1.66 & & & \\
\hline$\%$ Stdev & NA & $7.7 \%$ & & & \\
\hline
\end{tabular}

*Yield Stress was taken as the maximum in the curve between 0 and $100 \mathrm{sec}^{-1}$ since the curve did not properly reflect a Bingham material before shearing. Plastic viscosity could not be determined for the same reason.

Sheared Results (Down Flow Curve)

\begin{tabular}{|c|c|c|c|c|c|}
\hline & \multirow{2}{*}{$\begin{array}{c}\text { Plastic } \\
\text { Viscosity } \\
(\mathrm{cP})\end{array}$} & \multirow{2}{*}{$\begin{array}{c}\text { Yield } \\
\text { Stress } \\
(\mathrm{Pa}) \\
\end{array}$} & & & \multirow{2}{*}{$\begin{array}{l}\text { Range, } \\
\sec ^{-1}\end{array}$} \\
\hline Sample I.D. & & & $\mathrm{R}^{2}$ & Date & \\
\hline $\begin{array}{c}\text { ISPM-T1-0002- } \\
\text { 15\%_R1 }\end{array}$ & 21.70 & 4.62 & 0.9986 & $5 / 4 / 2005$ & $50-600$ \\
\hline $\begin{array}{c}\text { ISPM-T1-0002- } \\
15 \% \text { R2 }\end{array}$ & 21.34 & 4.53 & 0.9986 & $5 / 4 / 2005$ & $50-600$ \\
\hline Average & 21.52 & 4.58 & & & \\
\hline Stdev & 0.25 & 0.06 & & & \\
\hline$\%$ Stdev & $1.2 \%$ & $1.4 \%$ & & & \\
\hline
\end{tabular}


Figure B - 5: Rheology of ISPM-T6-asis SRAT Product
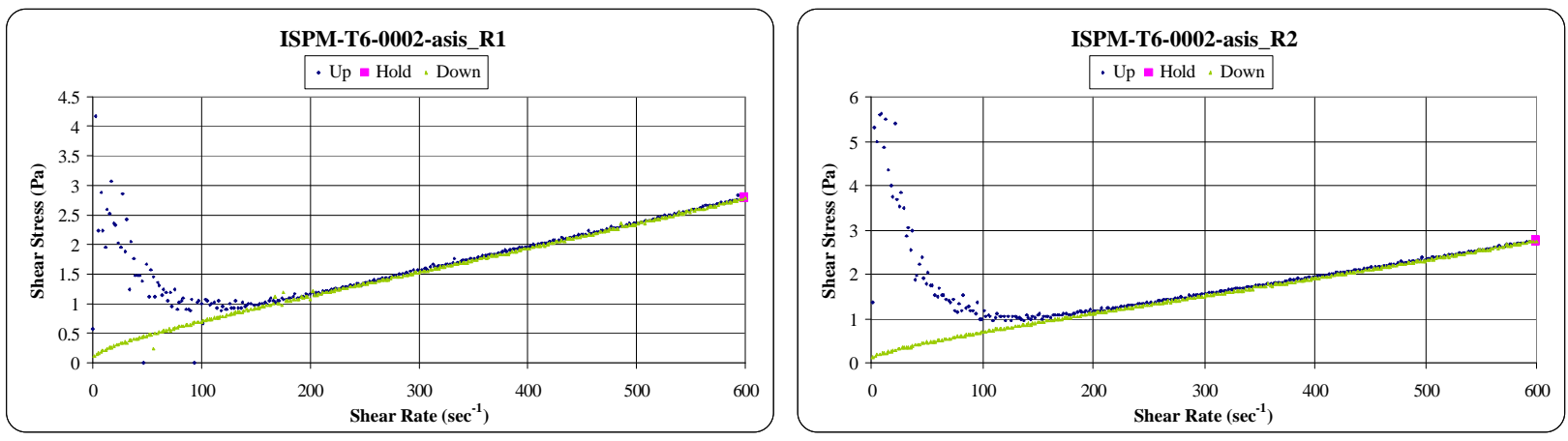

Unsheared Results (Up Flow Curve)

\begin{tabular}{|c|c|c|c|c|c|}
\hline Sample I.D. & $\begin{array}{c}\text { Plastic } \\
\text { Viscosity } \\
(\mathrm{cP})\end{array}$ & $\begin{array}{c}\text { Yield } \\
\text { Stress (Pa) }\end{array}$ & R2 & Date & $\begin{array}{c}\text { Range, } \\
\text { sec }^{-1}\end{array}$ \\
\cline { 1 - 3 } $\begin{array}{c}\text { ISPM-T6-0002- } \\
\text { asis_R1 }\end{array}$ & 4.05 & 0.35 & 0.9990 & $4 / 27 / 2005$ & $150-600$ \\
\cline { 1 - 3 } $\begin{array}{c}\text { ISPM-T6-0002- } \\
\text { asis_R2 }\end{array}$ & 3.90 & 0.39 & 0.9988 & $4 / 27 / 2005$ & $150-600$ \\
\cline { 1 - 3 } Average & 3.98 & 0.37 & & & \\
\cline { 1 - 3 } \%tdev & 0.11 & 0.03 & & \multicolumn{2}{|c}{} \\
\cline { 1 - 3 } \%Stdev & $2.7 \%$ & $7.6 \%$ & &
\end{tabular}

Sheared Results (Down Flow Curve)

\begin{tabular}{|c|c|c|c|c|c|}
\hline Sample I.D. & $\begin{array}{c}\text { Plastic } \\
\text { Viscosity } \\
(\mathrm{cP})\end{array}$ & $\begin{array}{c}\text { Yield } \\
\text { Stress (Pa) }\end{array}$ & R2 & Date & $\begin{array}{c}\text { Range, } \\
\text { sec }^{-1}\end{array}$ \\
\cline { 1 - 3 } $\begin{array}{c}\text { ISPM-T6-0002- } \\
\text { asis_R1 }\end{array}$ & 4.13 & 0.29 & 0.9984 & $4 / 27 / 2005$ & $50-600$ \\
\cline { 1 - 3 } $\begin{array}{c}\text { ISPM-T6-0002- } \\
\text { asis_R2 }\end{array}$ & 4.06 & 0.28 & 0.9996 & $4 / 27 / 2005$ & $50-600$ \\
\cline { 1 - 3 } Average & 4.10 & 0.29 & & & \\
\cline { 1 - 3 } Stdev & 0.05 & 0.01 & & & \\
\cline { 1 - 3 } \% & $1.2 \%$ & $2.5 \%$ & & &
\end{tabular}


Figure B - 6: Rheology of ISPM-T6-10\% SRAT Product
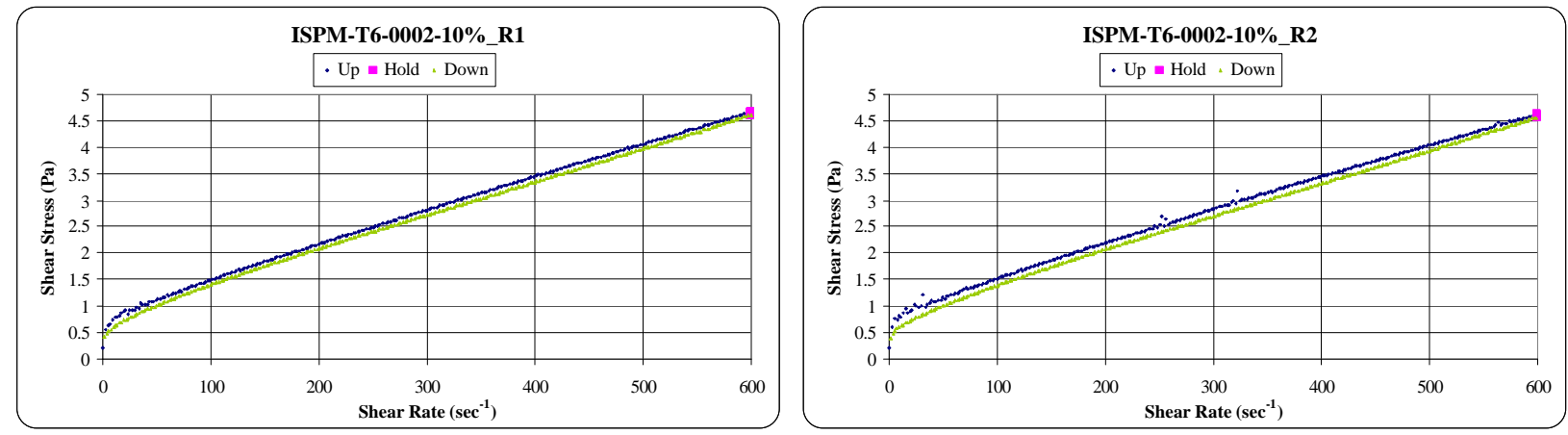

Unsheared Results (Up Flow Curve)

\begin{tabular}{|c|c|c|c|c|c|}
\hline Sample I.D. & $\begin{array}{c}\text { Plastic } \\
\text { Viscosity } \\
(\mathrm{cP})\end{array}$ & $\begin{array}{c}\text { Yield } \\
\text { Stress } \\
(\mathrm{Pa})\end{array}$ & $\mathrm{R}^{2}$ & Date & $\begin{array}{c}\text { Range, } \\
\text { sec }^{-1}\end{array}$ \\
\cline { 1 - 3 } $\begin{array}{c}\text { ISPM-T6-0002- } \\
\text { 10\%_R1 }\end{array}$ & 6.37 & 0.88 & 0.9994 & $4 / 27 / 2005$ & $50-600$ \\
\cline { 1 - 3 } $\begin{array}{c}\text { ISPM-T6-0002- } \\
\text { 10\%_R2 }\end{array}$ & 6.24 & 0.93 & 0.9988 & $4 / 27 / 2005$ & $50-600$ \\
\cline { 1 - 3 } Average & 6.31 & 0.91 & & & \\
\cline { 1 - 3 } Stdev & 0.09 & 0.04 & & & \\
\cline { 1 - 3 } \%Stdev & $1.5 \%$ & $3.9 \%$ & & &
\end{tabular}

Sheared Results (Down Flow Curve)

\begin{tabular}{|c|c|c|c|c|c|}
\hline Sample I.D. & $\begin{array}{c}\text { Plastic } \\
\text { Viscosity } \\
\text { (cP) }\end{array}$ & $\begin{array}{c}\text { Yield } \\
\text { Stress } \\
(\mathrm{Pa}) \\
\end{array}$ & $\mathrm{R}^{2}$ & Date & $\begin{array}{l}\text { Range, } \\
\sec ^{-1}\end{array}$ \\
\hline $\begin{array}{c}\text { ISPM-T6-0002- } \\
10 \% \text { R1 }\end{array}$ & 6.40 & 0.78 & 0.9996 & $4 / 27 / 2005$ & $50-600$ \\
\hline $\begin{array}{c}\text { ISPM-T6-0002- } \\
10 \% \text { R2 }\end{array}$ & 6.33 & 0.78 & 0.9994 & $4 / 27 / 2005$ & $50-600$ \\
\hline Average & 6.37 & 0.78 & & & \\
\hline Stdev & 0.05 & 0.00 & & & \\
\hline$\%$ Stdev & $0.8 \%$ & $0.0 \%$ & & & \\
\hline
\end{tabular}


Figure B - 7: Rheology of ISPM-T6-12\% SRAT Product
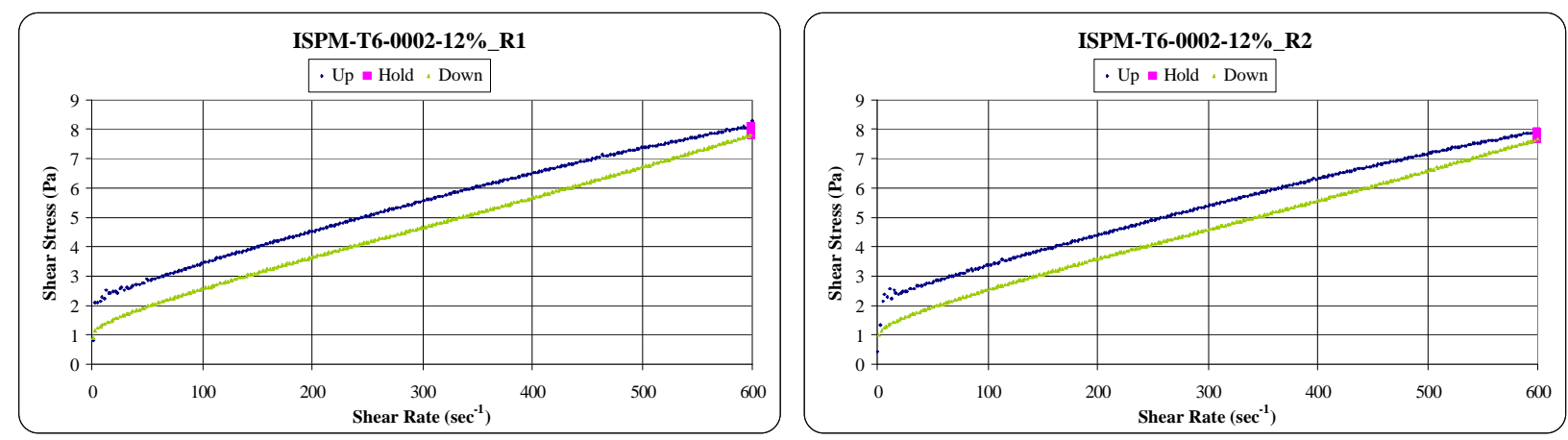

Unsheared Results (Up Flow Curve)

\begin{tabular}{|c|c|c|c|c|c|}
\hline Sample I.D. & $\begin{array}{c}\text { Plastic } \\
\text { Viscosity } \\
\text { (cP) }\end{array}$ & $\begin{array}{c}\text { Yield } \\
\text { Stress } \\
(\mathrm{Pa})\end{array}$ & $\mathrm{R}^{2}$ & Date & $\begin{array}{l}\text { Range, } \\
\mathrm{sec}^{-1}\end{array}$ \\
\hline $\begin{array}{c}\text { ISPM-T6-0002- } \\
\text { 12\%_R1 }\end{array}$ & 9.61 & 2.57 & 0.9960 & $4 / 27 / 2005$ & $50-600$ \\
\hline $\begin{array}{c}\text { ISPM-T6-0002- } \\
12 \% \text { R2 }\end{array}$ & 9.34 & 2.51 & 0.9972 & $4 / 27 / 2005$ & $50-600$ \\
\hline Average & 9.48 & 2.54 & & & \\
\hline Stdev & 0.19 & 0.04 & & & \\
\hline$\%$ Stdev & $2.0 \%$ & $1.7 \%$ & & & \\
\hline
\end{tabular}

Sheared Results (Down Flow Curve)

\begin{tabular}{|c|c|c|c|c|c|}
\hline Sample I.D. & $\begin{array}{c}\text { Plastic } \\
\text { Viscosity } \\
(\mathrm{cP})\end{array}$ & $\begin{array}{c}\text { Yield } \\
\text { Stress } \\
(\mathrm{Pa})\end{array}$ & $\mathrm{R}^{2}$ & Date & $\begin{array}{c}\text { Range, } \\
\mathrm{sec}^{-1}\end{array}$ \\
\hline $\begin{array}{c}\text { ISPM-T6-0002- } \\
\text { 12\%_R1 }\end{array}$ & 10.39 & 1.53 & 0.9998 & $4 / 27 / 2005$ & $50-600$ \\
\cline { 1 - 3 } $\begin{array}{c}\text { ISPM-T6-0002- } \\
\text { 12\%_R2 }\end{array}$ & 10.14 & 1.53 & 0.9998 & $4 / 27 / 2005$ & $50-600$ \\
\hline Average & 10.27 & 1.53 & & & \\
\cline { 1 - 3 } Stdev & 0.18 & 0.00 & & & \\
\cline { 1 - 3 } \% & $1.7 \%$ & $0.0 \%$ & & &
\end{tabular}


Figure B - 8: Rheology of ISPM-T6-15\% SRAT Product
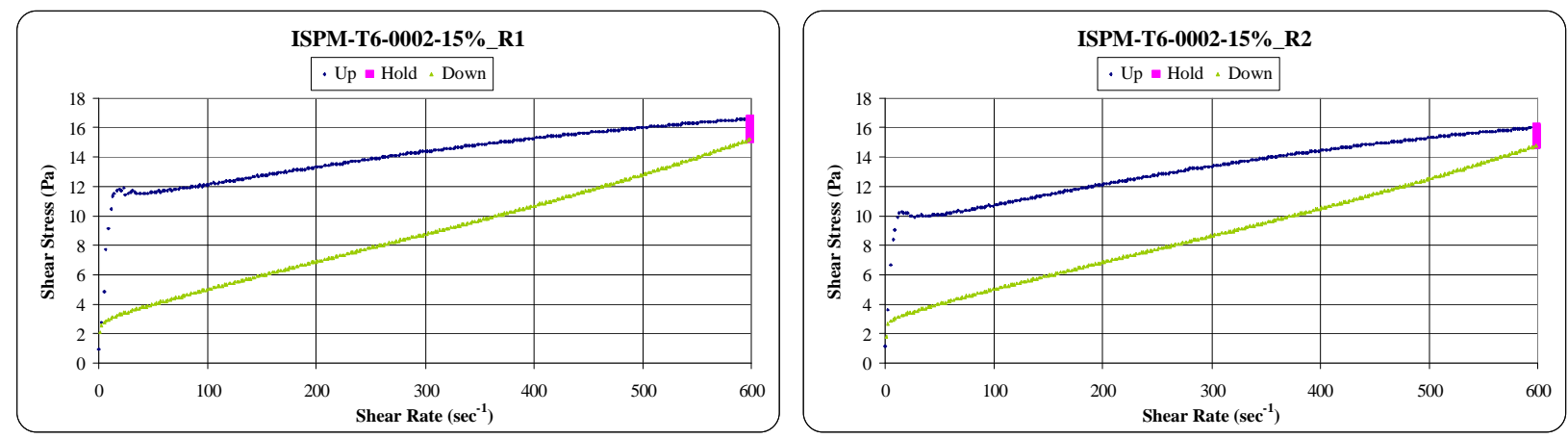

Unsheared Results (Up Flow Curve)

\begin{tabular}{|c|c|c|c|c|c|}
\hline Sample I.D. & $\begin{array}{c}\text { Plastic } \\
\text { Viscosity } \\
(\mathrm{cP})\end{array}$ & $\begin{array}{c}\text { Yield } \\
\text { Stress } \\
(\mathrm{Pa})\end{array}$ & $\mathrm{R}^{2}$ & Date & $\begin{array}{l}\text { Range, } \\
\sec ^{-1}\end{array}$ \\
\hline $\begin{array}{c}\text { ISPM-T6-0002- } \\
15 \% \text { R1 }\end{array}$ & 9.28 & 11.40 & 0.9874 & $5 / 3 / 2005$ & $50-600$ \\
\hline $\begin{array}{c}\text { ISPM-T6-0002- } \\
15 \% \text { R2 }\end{array}$ & 10.95 & 9.88 & 0.9878 & $5 / 3 / 2005$ & $50-600$ \\
\hline Average & 10.12 & 10.64 & & & \\
\hline Stdev & 1.18 & 1.07 & & & \\
\hline$\%$ Stdev & $11.7 \%$ & $10.1 \%$ & & & \\
\hline
\end{tabular}

Sheared Results (Down Flow Curve)

\begin{tabular}{|c|c|c|c|c|c|}
\hline Sample I.D. & $\begin{array}{c}\text { Plastic } \\
\text { Viscosity } \\
(\mathrm{cP})\end{array}$ & $\begin{array}{c}\text { Yield } \\
\text { Stress } \\
(\mathrm{Pa})\end{array}$ & $\mathrm{R}^{2}$ & Date & $\begin{array}{c}\text { Range, } \\
\text { sec }^{-1}\end{array}$ \\
\cline { 1 - 3 } $\begin{array}{c}\text { ISPM-T6-0002- } \\
\text { 15\%_R1 }\end{array}$ & 19.83 & 2.91 & 0.9982 & $5 / 3 / 2005$ & $50-600$ \\
\cline { 1 - 3 } $\begin{array}{c}\text { ISPM-T6-0002- } \\
\text { 15\%_R2 }\end{array}$ & 19.04 & 3.02 & 0.9988 & $5 / 3 / 2005$ & $50-600$ \\
\hline Average & 19.44 & 2.97 & & & \\
\cline { 1 - 3 } Stdev & 0.56 & 0.08 & & & \\
\cline { 1 - 3 } \%Stdev & $2.9 \%$ & $2.6 \%$ & & &
\end{tabular}


Figure B - 9: Rheology of ISPM-T7-asis SRAT Product
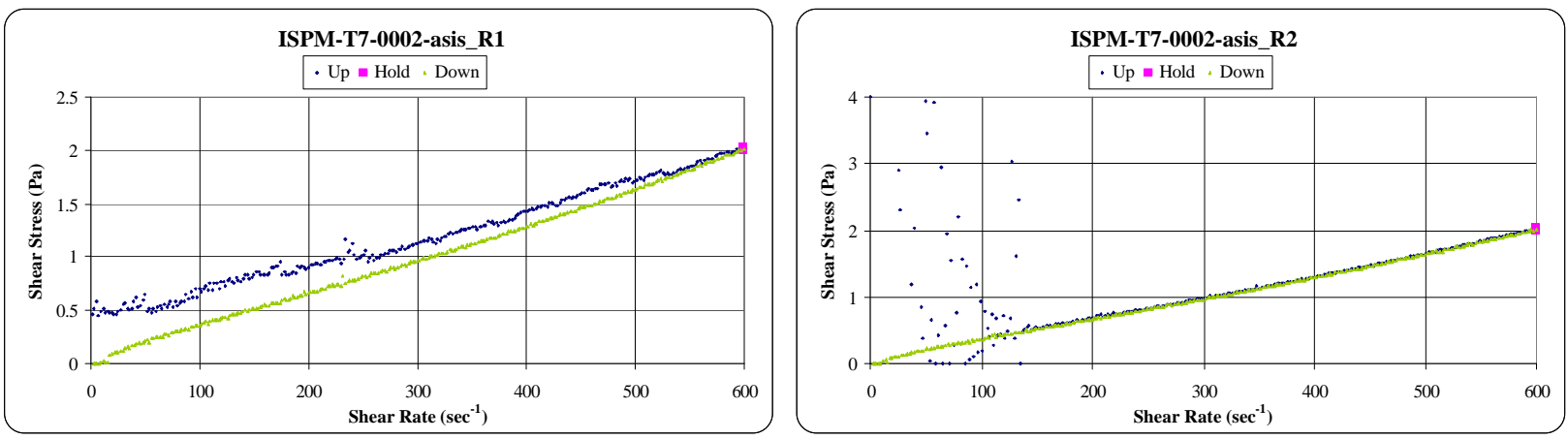

Unsheared Results (Up Flow Curve)

\begin{tabular}{|c|c|c|c|c|c|}
\hline Sample I.D. & $\begin{array}{c}\text { Plastic } \\
\text { Viscosity } \\
(\mathrm{cP})\end{array}$ & $\begin{array}{c}\text { Yield } \\
\text { Stress } \\
(\mathrm{Pa})\end{array}$ & $\mathrm{R}^{2}$ & Date & $\begin{array}{l}\text { Range, } \\
\sec ^{-1}\end{array}$ \\
\hline $\begin{array}{c}\text { ISPM-T7-0002- } \\
\text { asis_R1 }\end{array}$ & 2.67 & 0.37 & 0.9900 & $4 / 27 / 2005$ & $50-600$ \\
\hline $\begin{array}{c}\text { ISPM-T7-0002- } \\
\text { asis_R2 }\end{array}$ & 2.36 & 0.41 & 0.4306 & $4 / 27 / 2005$ & $50-600$ \\
\hline Average & 2.52 & 0.39 & & & \\
\hline Stdev & 0.22 & 0.03 & & & \\
\hline$\%$ Stdev & $8.7 \%$ & $7.3 \%$ & & & \\
\hline
\end{tabular}

Sheared Results (Down Flow Curve)

\begin{tabular}{|c|c|c|c|c|c|}
\hline Sample I.D. & $\begin{array}{c}\text { Plastic } \\
\text { Viscosity } \\
\text { (cP) }\end{array}$ & $\begin{array}{c}\text { Yield } \\
\text { Stress } \\
(\mathrm{Pa})\end{array}$ & $\mathrm{R}^{2}$ & Date & $\begin{array}{l}\text { Range, } \\
\mathrm{sec}^{-1}\end{array}$ \\
\hline $\begin{array}{c}\text { ISPM-T7-0002- } \\
\text { asis_R1 }\end{array}$ & 3.22 & 0.02 & 0.9978 & $4 / 27 / 2005$ & $\begin{array}{l}50- \\
600\end{array}$ \\
\hline $\begin{array}{l}\text { ISPM-T7-0002- } \\
\text { asis_R2 }\end{array}$ & 3.22 & 0.02 & 0.9980 & $4 / 27 / 2005$ & $\begin{array}{l}50- \\
600\end{array}$ \\
\hline Average & 3.22 & 0.02 & & & \\
\hline Stdev & 0.00 & 0.00 & & & \\
\hline$\%$ Stdev & $0.0 \%$ & $0.0 \%$ & & & \\
\hline
\end{tabular}


Figure B - 10: Rheology of ISPM-T7-10\% SRAT Product
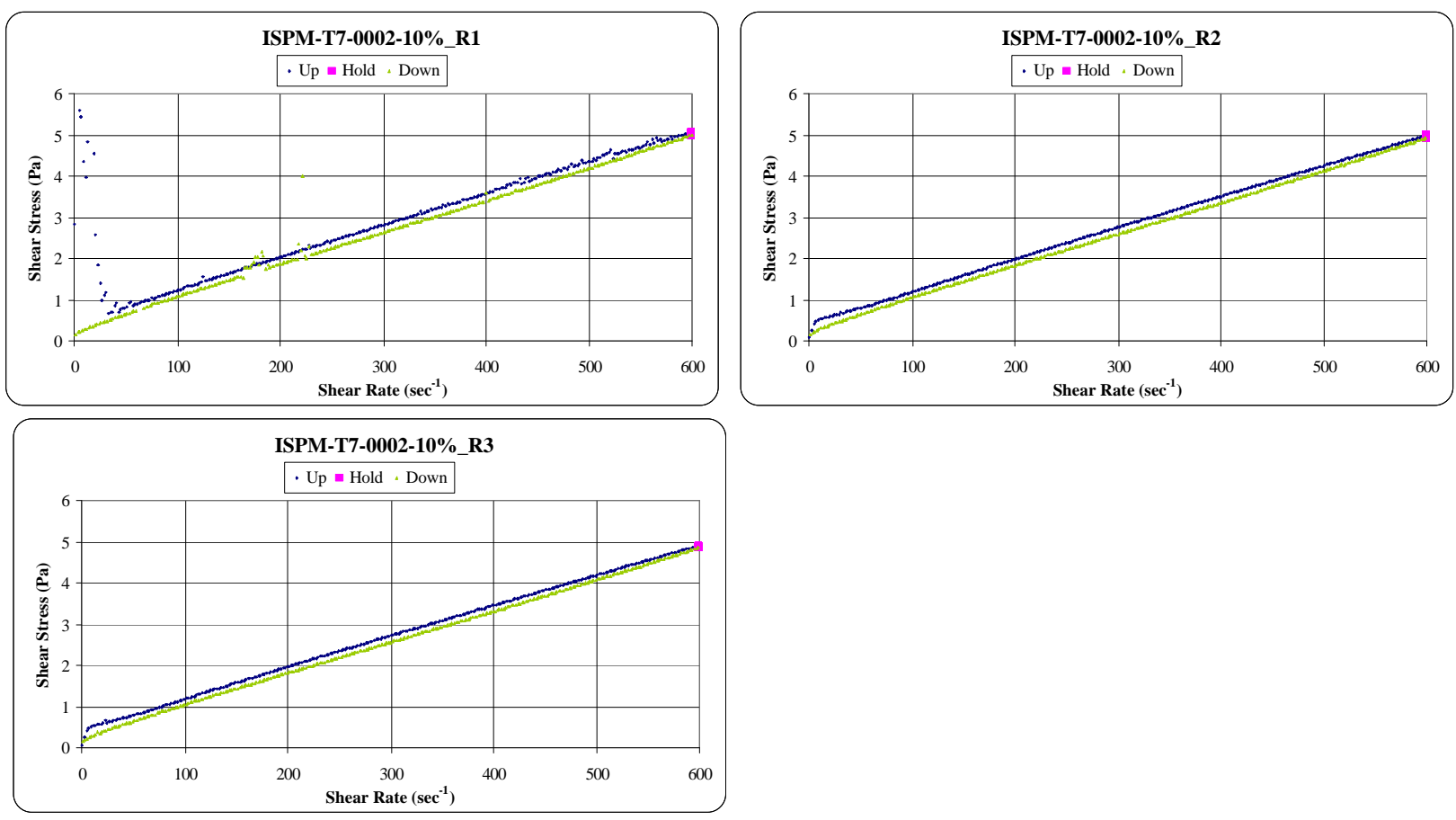

Unsheared Results (Up Flow Curve)

\begin{tabular}{|c|c|c|c|c|c|}
\hline Sample I.D. & $\begin{array}{c}\text { Plastic } \\
\text { Viscosity } \\
(\mathrm{cP})\end{array}$ & $\begin{array}{c}\text { Yield } \\
\text { Stress } \\
(\mathrm{Pa})\end{array}$ & $\mathrm{R}^{2}$ & Date & $\begin{array}{c}\text { Range, } \\
\text { sec }^{-1}\end{array}$ \\
\hline ISPM-T7-0002-10\%_R1 & 7.75 & 0.47 & 0.9994 & $4 / 27 / 2005$ & $50-600$ \\
\hline ISPM-T7-0002-10\%_R2 & 7.61 & 0.45 & 0.9998 & $4 / 27 / 2005$ & $50-600$ \\
\hline ISPM-T7-0002-10\%_R3 & 7.47 & 0.46 & 0.9998 & $4 / 27 / 2005$ & $50-600$ \\
\cline { 1 - 3 } Average & 7.61 & 0.46 & \multicolumn{3}{|c}{} \\
\cline { 1 - 3 } \%tdev & 0.14 & 0.01 & & & \\
\cline { 1 - 3 } \%Stdev & $1.8 \%$ & $2.2 \%$ & & &
\end{tabular}

Sheared Results (Down Flow Curve)

\begin{tabular}{|c|c|c|c|c|c|}
\hline Sample I.D. & $\begin{array}{c}\text { Plastic } \\
\text { Viscosity } \\
(\mathrm{cP})\end{array}$ & $\begin{array}{c}\text { Yield } \\
\text { Stress } \\
(\mathrm{Pa})\end{array}$ & $\mathrm{R}^{2}$ & Date & $\begin{array}{c}\text { Range, } \\
\text { sec }^{-1}\end{array}$ \\
\hline ISPM-T7-0002-10\%_R1 & 7.72 & 0.33 & 0.9883 & $4 / 27 / 2005$ & $50-600$ \\
\hline ISPM-T7-0002-10\%_R2 & 7.70 & 0.28 & 0.9999 & $4 / 27 / 2005$ & $50-600$ \\
\hline ISPM-T7-0002-10\%_R3 & 7.57 & 0.29 & 0.9999 & $4 / 27 / 2005$ & $50-600$ \\
\cline { 1 - 3 } Average & 7.64 & 0.29 & \multicolumn{3}{|l}{} \\
\cline { 1 - 3 } \%tdev & 0.09 & 0.01 & & & \\
\cline { 1 - 3 } \%Stdev & $1.2 \%$ & $2.5 \%$ & & &
\end{tabular}


Figure B - 11: Rheology of ISPM-T7-12\% SRAT Product
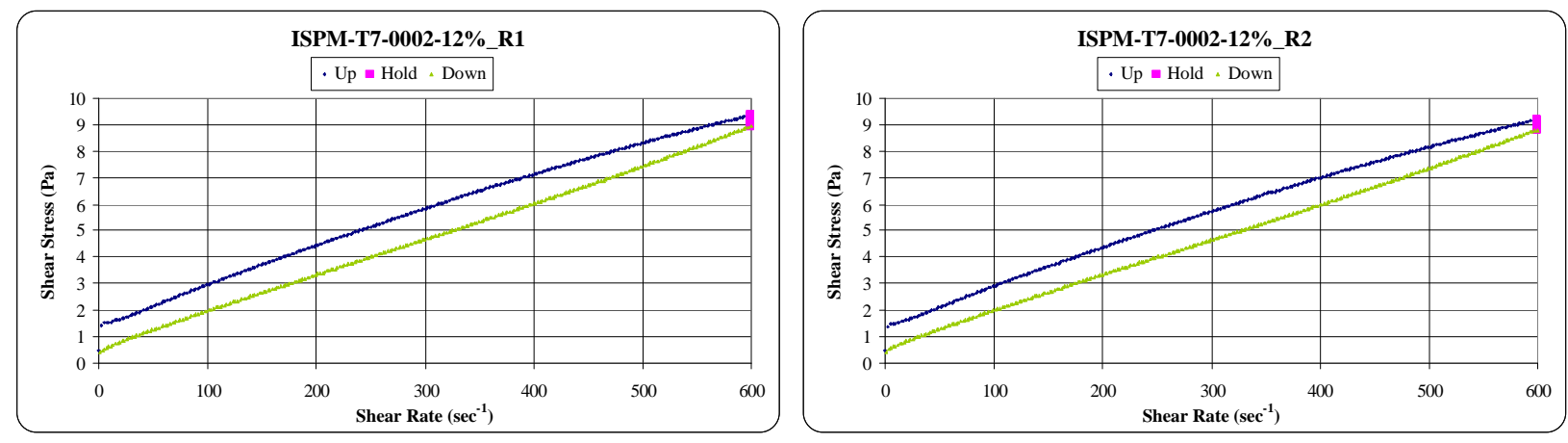

Unsheared Results (Up Flow Curve)

\begin{tabular}{|c|c|c|c|c|c|}
\hline Sample I.D. & $\begin{array}{c}\text { Plastic } \\
\text { Viscosity } \\
\text { (cP) }\end{array}$ & $\begin{array}{c}\text { Yield } \\
\text { Stress } \\
(\mathrm{Pa})\end{array}$ & $\mathrm{R}^{2}$ & Date & $\begin{array}{l}\text { Range, } \\
\mathrm{sec}^{-1}\end{array}$ \\
\hline $\begin{array}{c}\text { ISPM-T7-0002- } \\
12 \% \text { R1 }\end{array}$ & 13.10 & 1.78 & 0.9966 & $4 / 28 / 2005$ & $50-600$ \\
\hline $\begin{array}{c}\text { ISPM-T7-0002- } \\
12 \% \text { R2 }\end{array}$ & 12.86 & 1.74 & 0.9966 & $4 / 28 / 2005$ & $50-600$ \\
\hline Average & 12.98 & 1.76 & & & \\
\hline Stdev & 0.17 & 0.03 & & & \\
\hline$\%$ Stdev & $1.3 \%$ & $1.6 \%$ & & & \\
\hline
\end{tabular}

Sheared Results (Down Flow Curve)

\begin{tabular}{|c|c|c|c|c|c|}
\hline Sample I.D. & $\begin{array}{c}\text { Plastic } \\
\text { Viscosity } \\
(\mathrm{cP})\end{array}$ & $\begin{array}{c}\text { Yield } \\
\text { Stress } \\
(\mathrm{Pa})\end{array}$ & $\mathrm{R}^{2}$ & Date & $\begin{array}{c}\text { Range, } \\
\mathrm{sec}^{-1}\end{array}$ \\
\hline $\begin{array}{c}\text { ISPM-T7-0002- } \\
\text { 12\%_R1 }\end{array}$ & 13.74 & 0.57 & 0.9996 & $5 / 03 / 2005$ & $50-600$ \\
\cline { 1 - 3 } $\begin{array}{c}\text { ISPM-T7-0002- } \\
\text { 12\%_R2 }\end{array}$ & 13.47 & 0.63 & 0.9998 & $5 / 03 / 2005$ & $50-600$ \\
\hline Average & 13.61 & 0.60 & & & \\
\cline { 1 - 3 } Stdev & 0.19 & 0.04 & & & \\
\cline { 1 - 3 } \% & $1.4 \%$ & $7.1 \%$ & & &
\end{tabular}


Figure B - 12: Rheology of ISPM-T7-15\% SRAT Product
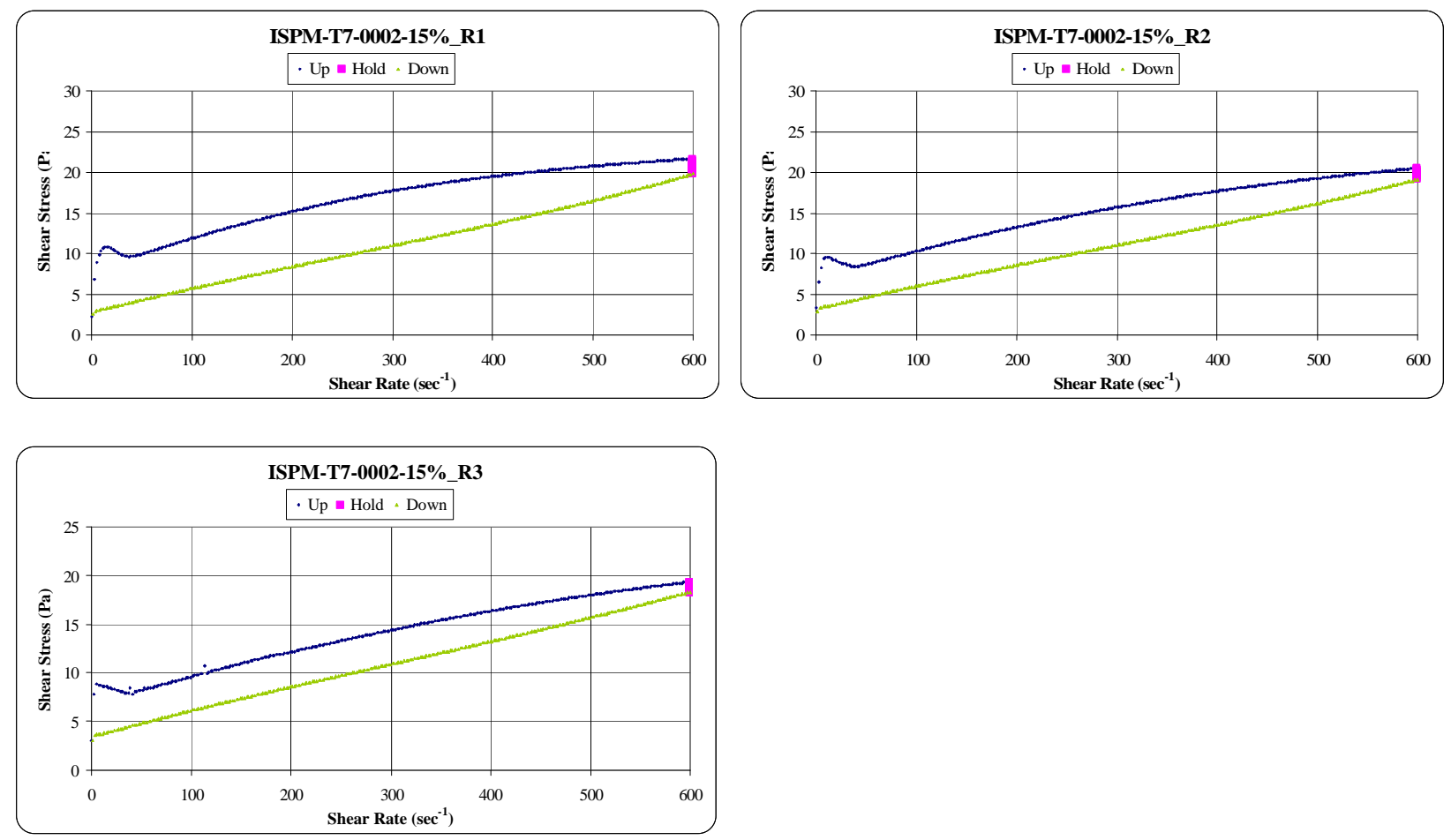

Unsheared Results (Up Flow Curve)

\begin{tabular}{|c|c|c|c|c|c|}
\hline Sample I.D. & $\begin{array}{c}\text { Plastic } \\
\text { Viscosity } \\
\text { (cP) }\end{array}$ & $\begin{array}{c}\text { Yield } \\
\text { Stress (Pa) }\end{array}$ & $\mathrm{R}^{2}$ & Date & $\begin{array}{l}\text { Range, } \\
\sec ^{-1}\end{array}$ \\
\hline ISPM-T7-0002-15\%_R1 & 20.67 & 10.65 & 0.9528 & $5 / 3 / 2005$ & $50-600$ \\
\hline ISPM-T7-0002-15\%_R2 & 21.30 & 8.73 & 0.9787 & $5 / 3 / 2005$ & $50-600$ \\
\hline ISPM-T7-0002-15\%_R3 & 20.11 & 8.00 & 0.9886 & $5 / 3 / 2005$ & $50-600$ \\
\hline Average & 20.69 & 9.13 & & & \\
\hline Stdev & 0.60 & 1.37 & & & \\
\hline$\%$ Stdev & $2.9 \%$ & $15.0 \%$ & & & \\
\hline
\end{tabular}

Sheared Results (Down Flow Curve)

\begin{tabular}{|c|c|c|c|c|c|}
\hline Sample I.D. & $\begin{array}{c}\text { Plastic } \\
\text { Viscosity } \\
\text { (cP) }\end{array}$ & $\begin{array}{c}\text { Yield } \\
\text { Stress }(\mathrm{Pa})\end{array}$ & $\mathrm{R}^{2}$ & Date & $\begin{array}{l}\text { Range, } \\
\sec ^{-1}\end{array}$ \\
\hline ISPM-T7-0002-15\%_R1 & 27.35 & 2.87 & 0.9988 & $5 / 3 / 2005$ & $50-600$ \\
\hline ISPM-T7-0002-15\%_R2 & 25.68 & 3.37 & 0.9994 & $5 / 3 / 2005$ & $50-600$ \\
\hline ISPM-T7-0002-15\%_R3 & 23.99 & 3.71 & 0.9998 & $5 / 3 / 2005$ & $50-600$ \\
\hline Average & 25.67 & 3.32 & & & \\
\hline Stdev & 1.68 & 0.42 & & & \\
\hline$\%$ Stdev & $6.5 \%$ & $12.7 \%$ & & & \\
\hline
\end{tabular}


Figure B - 13: Rheology of ISPM-T8-asis SRAT Product
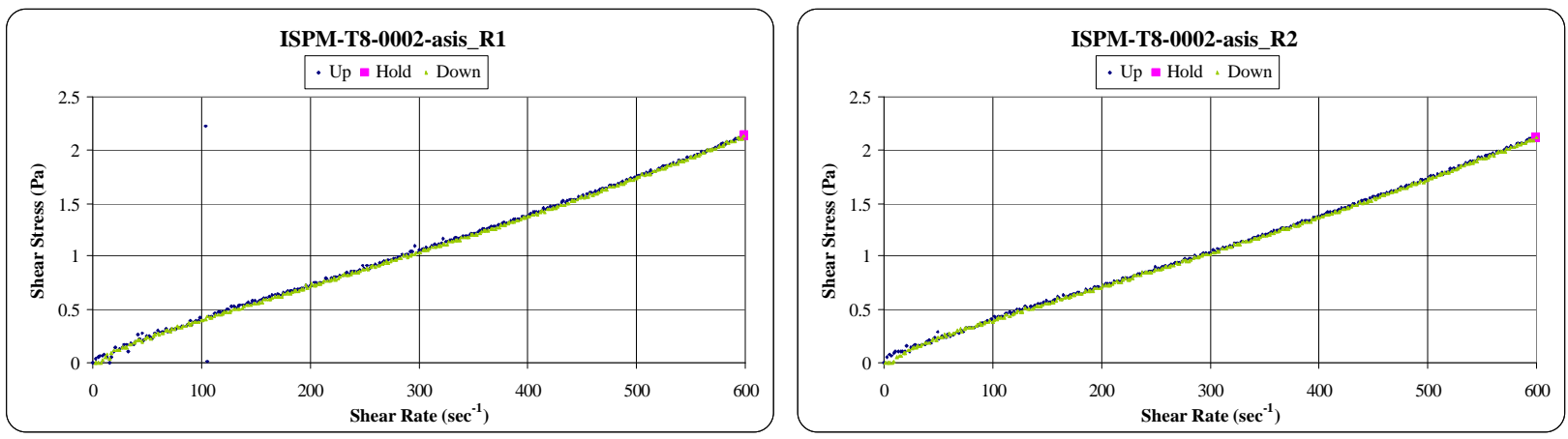

Unsheared Results (Up Flow Curve)

\begin{tabular}{|c|c|c|c|c|c|}
\hline Sample I.D. & $\begin{array}{c}\text { Plastic } \\
\text { Viscosity } \\
\text { (cP) }\end{array}$ & $\begin{array}{c}\text { Yield } \\
\text { Stress } \\
(\mathrm{Pa})\end{array}$ & $\mathrm{R}^{2}$ & Date & $\begin{array}{l}\text { Range, } \\
\mathrm{sec}^{-1}\end{array}$ \\
\hline $\begin{array}{c}\text { ISPM-T8-0002- } \\
\text { asis_R1 }\end{array}$ & 3.38 & 0.06 & 0.9994 & $4 / 27 / 2005$ & $\begin{array}{l}50- \\
600\end{array}$ \\
\hline $\begin{array}{l}\text { ISPM-T8-0002- } \\
\text { asis_R2 } \\
\end{array}$ & 3.37 & 0.05 & 0.9992 & $4 / 27 / 2005$ & $\begin{array}{l}50- \\
600 \\
\end{array}$ \\
\hline Average & 3.38 & 0.06 & & & \\
\hline Stdev & 0.01 & 0.01 & & & \\
\hline$\%$ Stdev & $0.2 \%$ & $12.9 \%$ & & & \\
\hline
\end{tabular}

Sheared Results (Down Flow Curve)

\begin{tabular}{|c|c|c|c|c|c|}
\hline Sample I.D. & $\begin{array}{c}\text { Plastic } \\
\text { Viscosity } \\
(\mathrm{cP})\end{array}$ & $\begin{array}{c}\text { Yield } \\
\text { Stress } \\
(\mathrm{Pa}) \\
\end{array}$ & $\mathrm{R}^{2}$ & Date & $\begin{array}{l}\text { Range, } \\
\sec ^{-1}\end{array}$ \\
\hline $\begin{array}{l}\text { ISPM-T8-0002- } \\
\text { asis_R1 }\end{array}$ & 3.38 & 0.04 & 0.9984 & $4 / 27 / 2005$ & $\begin{array}{l}50- \\
600 \\
\end{array}$ \\
\hline $\begin{array}{c}\text { ISPM-T8-0002- } \\
\text { asis_R2 }\end{array}$ & 3.36 & 0.04 & 0.9984 & $4 / 27 / 2005$ & $\begin{array}{l}50- \\
600 \\
\end{array}$ \\
\hline Average & 3.37 & 0.04 & & & \\
\hline Stdev & 0.01 & 0.0 & & & \\
\hline$\%$ Stdev & $0.4 \%$ & $0.0 \%$ & & & \\
\hline
\end{tabular}


Figure B - 14: Rheology of ISPM-T8-10\% SRAT Product
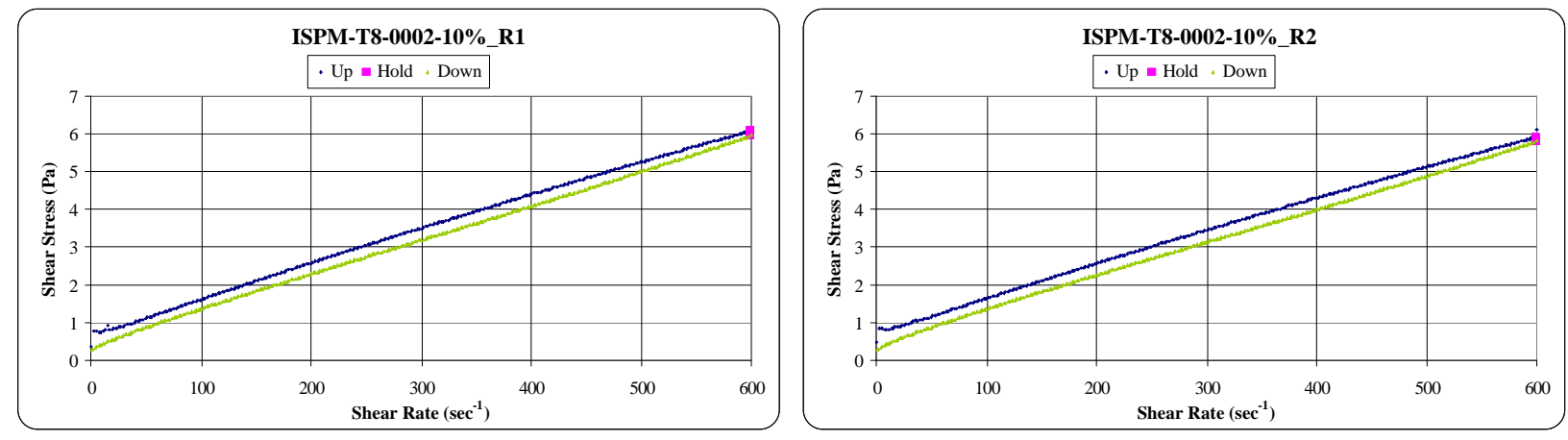

Unsheared Results (Up Flow Curve)

\begin{tabular}{|c|c|c|c|c|c|}
\hline Sample I.D. & $\begin{array}{c}\text { Plastic } \\
\text { Viscosity } \\
(\mathrm{cP})\end{array}$ & $\begin{array}{c}\text { Yield } \\
\text { Stress } \\
(\mathrm{Pa})\end{array}$ & $\mathrm{R}^{2}$ & Date & $\begin{array}{c}\text { Range, } \\
\text { sec }^{-1}\end{array}$ \\
\hline $\begin{array}{c}\text { ISPM-T8-0002- } \\
\text { 10\%_R1 }\end{array}$ & 9.00 & 0.76 & 0.9992 & $4 / 28 / 2005$ & $50-600$ \\
\hline $\begin{array}{c}\text { ISPM-T8-0002- } \\
\text { 10\%_R2 }\end{array}$ & 8.63 & 0.82 & 0.9992 & $4 / 28 / 2005$ & $50-600$ \\
\hline Average & 8.82 & 0.79 & & & \\
\cline { 1 - 3 } Stdev & 0.26 & 0.04 & & & \\
\cline { 1 - 3 } \%Stdev & $3.0 \%$ & $5.4 \%$ & & &
\end{tabular}

Sheared Results (Down Flow Curve)

\begin{tabular}{|c|c|c|c|c|c|}
\hline Sample I.D. & $\begin{array}{c}\text { Plastic } \\
\text { Viscosity } \\
(\mathrm{cP})\end{array}$ & $\begin{array}{c}\text { Yield } \\
\text { Stress } \\
(\mathrm{Pa}) \\
\end{array}$ & $\mathrm{R}^{2}$ & Date & $\begin{array}{l}\text { Range, } \\
\sec ^{-1}\end{array}$ \\
\hline $\begin{array}{c}\text { ISPM-T8-0002- } \\
10 \% \text { R1 }\end{array}$ & 9.10 & 0.46 & 1.0000 & $4 / 28 / 2005$ & $50-600$ \\
\hline $\begin{array}{c}\text { ISPM-T8-0002- } \\
10 \% \text { R2 }\end{array}$ & 8.81 & 0.48 & 1.0000 & $4 / 28 / 2005$ & $50-600$ \\
\hline Average & 8.96 & 0.47 & & & \\
\hline Stdev & 0.21 & 0.01 & & & \\
\hline$\%$ Stdev & $2.3 \%$ & $3.0 \%$ & & & \\
\hline
\end{tabular}


Figure B - 15: Rheology of ISPM-T8-12\% SRAT Product
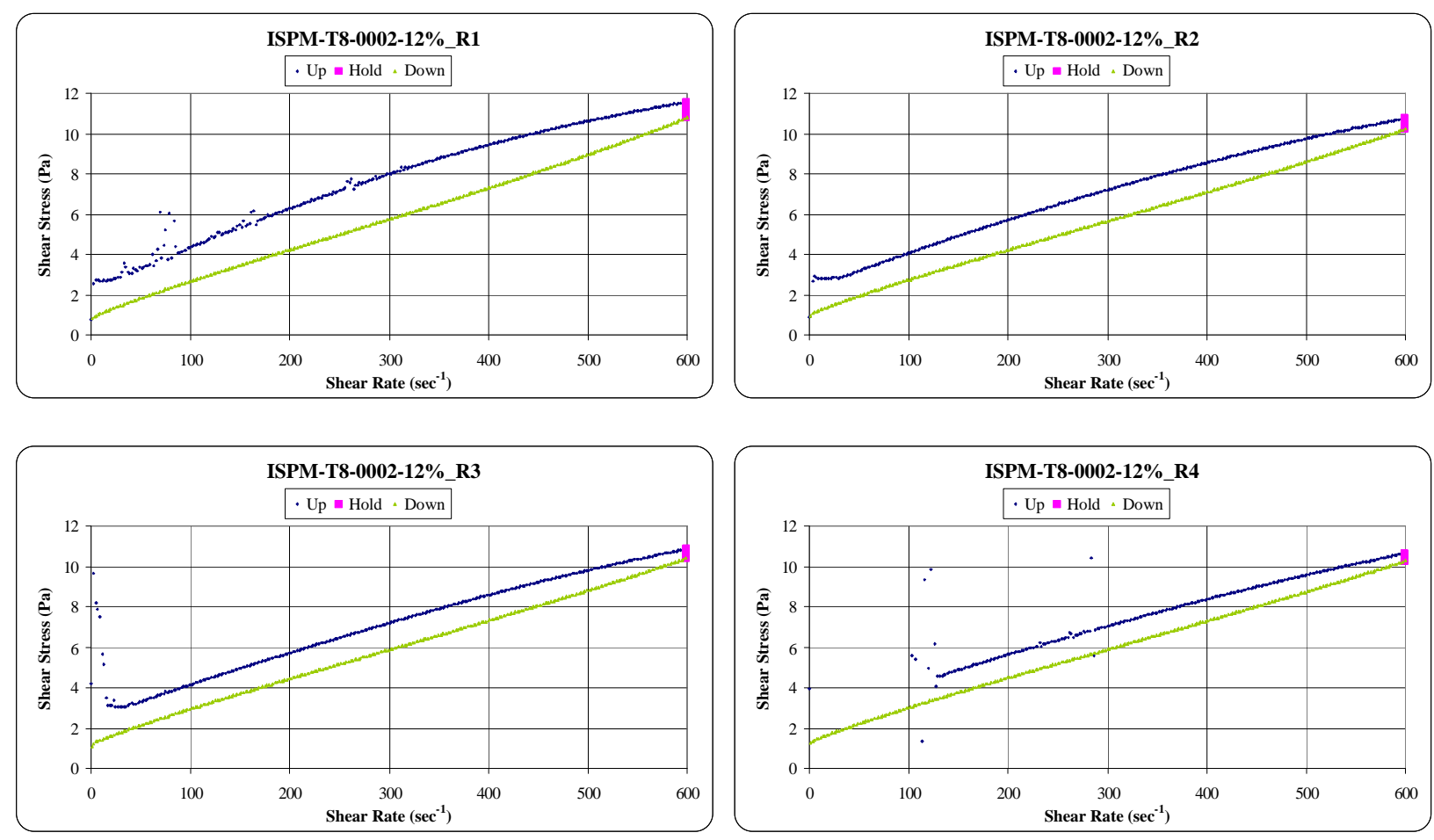

Unsheared Results (Up Flow Curve)

\begin{tabular}{|c|c|c|c|c|c|}
\hline Sample I.D. & $\begin{array}{c}\text { Plastic } \\
\text { Viscosity } \\
(\mathrm{cP})\end{array}$ & $\begin{array}{c}\text { Yield } \\
\text { Stress } \\
(\mathrm{Pa}) \\
\end{array}$ & $\mathrm{R}^{2}$ & Date & $\begin{array}{c}\text { Range }, \\
\sec ^{-1}\end{array}$ \\
\hline ISPM-T8-0002-12\%_R1 & 14.63 & 3.33 & 0.9803 & $4 / 28 / 2005$ & $50-600$ \\
\hline ISPM-T8-0002-12\%_R2 & 13.78 & 2.88 & 0.9934 & $4 / 28 / 2005$ & $50-600$ \\
\hline ISPM-T8-0002-12\%_R3 & 13.82 & 2.90 & 0.9960 & $5 / 09 / 2005$ & $50-600$ \\
\hline ISPM-T8-0002-12\%_R4 & 12.77 & 3.17 & 0.9742 & $5 / 09 / 2005$ & $150-600$ \\
\hline Average & 13.75 & 3.07 & & & \\
\hline Stdev & 0.76 & 0.22 & & & \\
\hline$\%$ Stdev & $5.5 \%$ & $7.1 \%$ & & & \\
\hline
\end{tabular}

Sheared Results (Down Flow Curve)

\begin{tabular}{|c|c|c|c|c|c|}
\hline Sample I.D. & $\begin{array}{c}\text { Plastic } \\
\text { Viscosity } \\
\text { (cP) }\end{array}$ & $\begin{array}{c}\text { Yield } \\
\text { Stress } \\
(\mathrm{Pa})\end{array}$ & $\mathrm{R}^{2}$ & Date & $\begin{array}{l}\text { Range, } \\
\sec ^{-1}\end{array}$ \\
\hline ISPM-T8-0002-12\%_R1 & 15.90 & 1.02 & 0.9994 & $4 / 28 / 2005$ & $50-600$ \\
\hline ISPM-T8-0002-12\%_R2 & 14.74 & 1.24 & 0.9998 & $4 / 28 / 2005$ & $50-600$ \\
\hline ISPM-T8-0002-12\%_R3 & 14.72 & 1.46 & 0.9998 & $5 / 09 / 2005$ & $50-600$ \\
\hline ISPM-T8-0002-12\%_R4 & 14.35 & 1.58 & 0.9998 & $5 / 09 / 2005$ & $50-600$ \\
\hline Average & 14.93 & 1.33 & & & \\
\hline Stdev & 0.67 & 0.25 & & & \\
\hline$\%$ Stdev & $4.5 \%$ & $18.7 \%$ & & & \\
\hline
\end{tabular}


Figure B - 16: Rheology of ISPM-T8-15\% SRAT Product
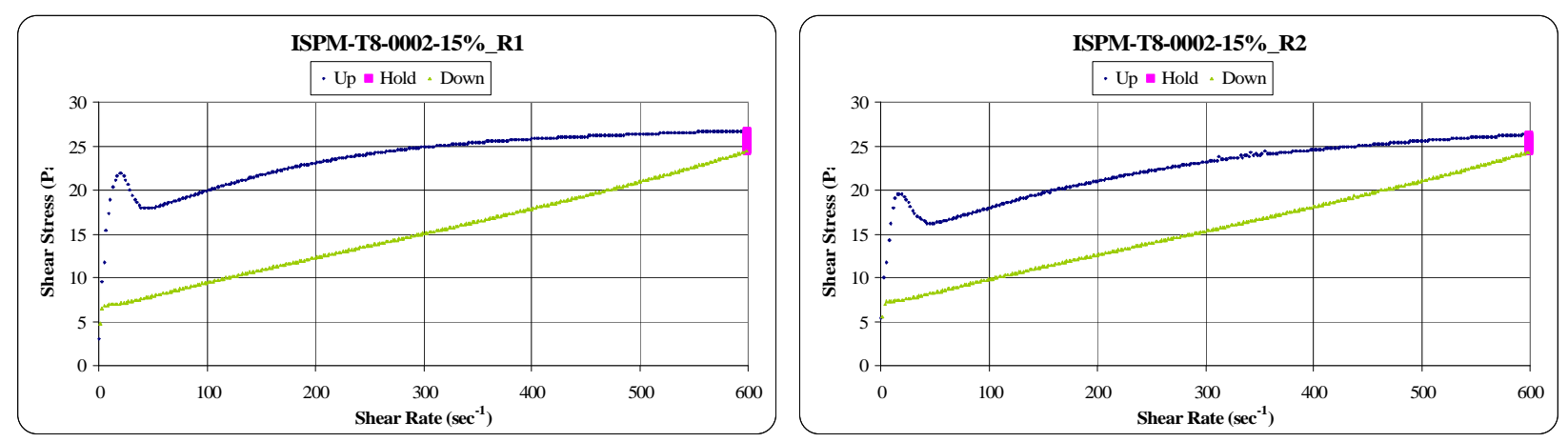

Unsheared Results (Up Flow Curve)

\begin{tabular}{|c|c|c|c|c|c|}
\hline Sample I.D. & $\begin{array}{c}\text { Plastic } \\
\text { Viscosity } \\
(\mathrm{cP})\end{array}$ & $\begin{array}{c}\text { Yield } \\
\text { Stress } \\
(\mathrm{Pa})\end{array}$ & \multirow{2}{*}{$\mathrm{R}^{2}$} & Date & Range, $\mathrm{sec}^{-1}$ \\
\cline { 1 - 3 } ISPM-T8-0002-15\%_R1 & 14.27 & 19.57 & 0.8681 & $5 / 4 / 2005$ & $50-600$ \\
\hline ISPM-T8-0002-15\%_R2 & 17.48 & 17.11 & 0.9347 & $5 / 4 / 2005$ & $50-600$ \\
\hline Average & 15.88 & 18.34 & \multicolumn{2}{|l}{} \\
\cline { 1 - 3 } Stdev & 2.27 & 1.74 & & & \\
\cline { 1 - 3 } \%Stdev & $14.3 \%$ & $9.5 \%$ & &
\end{tabular}

Sheared Results (Down Flow Curve)

\begin{tabular}{|c|c|c|c|c|c|}
\hline Sample I.D. & $\begin{array}{c}\text { Plastic } \\
\text { Viscosity } \\
(\mathrm{cP})\end{array}$ & $\begin{array}{c}\text { Yield } \\
\text { Stress } \\
(\mathrm{Pa}) \\
\end{array}$ & $\mathrm{R}^{2}$ & Date & Range, $\sec ^{-1}$ \\
\hline ISPM-T8-0002-15\%_R1 & 29.18 & 6.38 & 0.9988 & $5 / 4 / 2005$ & $50-600$ \\
\hline ISPM-T8-0002-15\%_R2 & 28.36 & 6.89 & 0.9992 & $5 / 4 / 2005$ & $50-600$ \\
\hline Average & 28.77 & 6.64 & & & \\
\hline Stdev & 0.58 & 0.36 & & & \\
\hline$\%$ Stdev & $2.0 \%$ & 5.4 & & & \\
\hline
\end{tabular}


WSRC-TR-2005-00294

Revision 0

This page intentionally left blank 


\section{Distribution:}

C. J. Bannochie, 773-42A

M. J. Barnes, 999-W

D. R. Best, 786-1A

N. E. Bibler, 773-A

D. B. Burns, 786-5A

T. B. Calloway, 999-W

D. A. Crowley, 773-A

R. E. Edwards, 773-A

R. E. Eibling, 999-W

T. L. Fellinger, 704-27S

J. M. Gillam, 766-H

J. R. Harbour, 773-42A

E. K. Hansen, 999-W

C. C. Herman, 773-42A

P. J. Hill, 766-H

J. F. Iaukea, 704-30S

C. M. Jantzen, 773-A

D. C. Koopman, 773-42A

D. P. Lambert, 773-A

S. L. Marra, 999-W

D. H. Miller, 999-W

M. S. Miller, 704-S

J. E. Occhipinti, 704-S

J. M. Pareizs, 773-A

P. M. Patel, 704-27S

D. K. Peeler, 999-W

J. W. Ray, 704-S

M. A. Rios-Armstrong, 766-H

H. B. Shah, 766-H

M. E. Smith, 999-W

M. E. Stone, 999-W

W. B. Van-Pelt, 704-S

G. G. Wicks, 773-A

M. F. Williams, 999-1W 